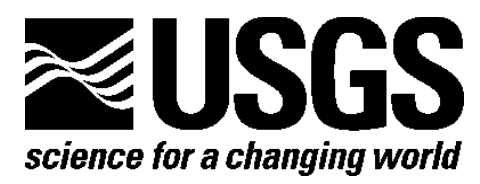

\title{
Evaluating Water Management Scenarios To Support Habitat Management for the Cape Sable Seaside Sparrow
}

By James M. Beerens, Stephanie S. Romañach, and Mark McKelvy

Open-File Report 2016-1107

U.S. Department of the Interior

U.S. Geological Survey 


\section{U.S. Department of the Interior \\ SALLY JEWELL, Secretary}

\section{U.S. Geological Survey}

Suzette M. Kimball, Director

U.S. Geological Survey, Reston, Virginia: 2016

For more information on the USGS-the Federal source for science about the Earth,

its natural and living resources, natural hazards, and the environment-visit

http://www.usgs.gov/ or call 1-888-ASK-USGS (1-888-275-8747).

For an overview of USGS information products, including maps, imagery, and publications, visit http://www.usgs.gov/pubprod/.

Any use of trade, firm, or product names is for descriptive purposes only and does not imply endorsement by the U.S. Government.

Although this information product, for the most part, is in the public domain, it also may contain copyrighted materials as noted in the text. Permission to reproduce copyrighted items must be secured from the copyright owner.

Suggested citation:

Beerens, J.M., Romañach, S.S., and McKelvy, Mark, 2016, Evaluating water management scenarios to support habitat management for the Cape Sable seaside sparrow: U.S. Geological Survey Open-File Report 2016-1107, 52 p., http://dx.doi.org/10.3133/ofr20161107.

ISSN 2331-1258 (online) 


\section{Acknowledgments}

This work was supported by the U.S. Geological Survey (USGS) and by the National Park Service, IAA\# P15PG00322. We thank Kevin Suir for hydrologic output conversion assistance. Many thanks to the five USGS research scientists and Victor Engel who provided helpful comments during their review of this document. 


\section{Contents}

Abstract
Introduction
Methods
Results
Summary and Conclusions
References Cited

\section{Figures}

Figure 1. Map of south Florida study area displaying Cape Sable seaside sparrow (CSSS) critical habitat subpopulations and survey sites.

Figure 2. Map showing locations of water management structures, Cape Sable seaside sparrow (CSSS) critical habitat subpopulations, and newly defined boundaries for the subpopulation A (A1 and A2).

Figure 3. Graph comparing mean 4-year hydroperiod to bird count at study sites. For Cape Sable Seaside sparrow counts of 1-6, 50 percent of sparrow observations (25-75-percent quantile [Q25-Q75]) are located at sites having a 4-year mean hydroperiod (prior to detection) between the black and the grey bars. Everglades Depth Estimation Network (EDEN) hydroperiods of less than 90 days support many (4-6) birds. The area between the dashed red line and solid blue line represents the 90- to 210-day range.

Figure 4. Graph comparing mean 4-year hydroperiod variability (HP SD) to bird count at study sites. Fifty percent of the Cape Sable Seaside sparrows observed (25-75-percent quantile) are located at sites with 4-year hydroperiod variability between the black and the grey bars. The area between the dashed red line and solid blue line represents the 17 - to 43 -day range.

Figure 5. Graph showing the sum of Cape Sable seaside sparrow observations over the period of record (200015) at a given site compared to hydroperiod interannual variability (HP SD); declining sparrow abundance is associated with higher interannual variability.....

Figure 6. Graph showing the sum of Cape Sable seaside sparrow observations over the period of record (200015) at a given site compared to mean subpopulation water depth. Sparrow survey data were used to identify the number of sparrows detected in a given Everglades Depth Estimation Network (EDEN) cell on a given day. The mean 
water depths for the subpopulation area containing this cell were averaged over all detections, under the assumption that mean depth would converge on suitable values the more a cell was frequented.

Figure 7. Maps showing, A, mean 4-year hydroperiod of baseline (1968-2004) condition, B, R2F scenario, $C$, difference between baseline and scenario, $D, 4$-year hydroperiod variability of baseline condition, and $E$, 4-year hydroperiod variability of scenario condition for Everglades National Park. Boundaries of Cape Sable seaside sparrow (CSSS) subpopulations A-F and populations A1 and A2 are denoted on the map.

Figure 8. Maps showing, A, mean 4-year hydroperiod of baseline (1968-2004) condition, B, R2G2 scenario, C, difference between baseline and scenario, $D, 4$-year hydroperiod variability of baseline condition, and $E$, 4-year hydroperiod variability of scenario condition for Everglades National Park. Boundaries of Cape Sable seaside sparrow (CSSS) subpopulations A-F and populations A1 and A2 are denoted on the map.

Figure 9. Maps showing, A, mean 4-year hydroperiod of baseline (1968-2004) condition, B, R2H scenario, $C$, difference between baseline and scenario, $D$, 4-year hydroperiod variability of baseline condition, and $E$, 4-year hydroperiod variability of scenario condition for Everglades National Park. Boundaries of Cape Sable seaside sparrow (CSSS) subpopulations A-F and populations A1 and A2 are denoted on the map. 15

Figure 10. Maps showing, A, mean 4-year hydroperiod of baseline (1968-2004) condition, B, R1E scenario, C, difference between baseline and scenario, $D$, 4-year hydroperiod variability of baseline condition, and $E$, 4-year hydroperiod variability of scenario condition for Everglades National Park. Boundaries of Cape Sable seaside sparrow (CSSS) subpopulations A-F and populations A1 and A2 are denoted on the map. 16

Figure 11. Graph showing mean water depth (1965-2005) for Everglades National Park (ENP) existing conditions baseline (ECB) run produced by the South Florida Water Management District (SFWMD) Regional Simulation Model (RSM). [cm, centimeter] 17

Figure 12. Graph showing area within subpopulations A, A1, and A2 (1968-2005) meeting FWS target 4-year hydroperiod of 90-210 days for 4 scenarios (R2F, R2G2, R2H, R1E) and the baseline condition (ECB). 18 
Figure 13. Graphs showing distribution and kernal probability curve of mean subpopulation water depths during, $A$, early (Mar-Apr) and, B, late (May-July 15) breeding seasons, and C, daily difference for R2F scenario and baseline condition for the R2F scenario, in subpopulation A. [cm, centimeter; CSSS, Cape Sable seaside sparrow] 19

Figure 14. Graphs showing distribution and kernal probability curve of mean subpopulation water depths during, $A$, early (Mar-Apr) and, B, late (May-July 15) breeding seasons, and C, daily difference in water depth between the R2G2 scenario and baseline condition (ECB), in subpopulation A. [cm, centimeter; CSSS, Cape Sable seaside sparrow] 20

Figure 15. Graphs showing distribution and kernal probability curve of mean subpopulation water depths during, $A$, early (Mar-Apr) and, $B$, late (May-July 15) breeding seasons, and C, daily difference in water depth between the R2H scenario and baseline condition (ECB), in subpopulation A. [cm, centimeter; CSSS, Cape Sable seaside sparrow].. 21

Figure 16. Graphs showing distribution and kernal probability curve of mean subpopulation water depths during, $A$, early (Mar-Apr) and, B, late (May-July 15) breeding seasons, and C, daily difference in water depth between the R1E scenario and baseline condition (ECB), in subpopulation A. [cm, centimeter; CSSS, Cape Sable seaside sparrow].. 22 Figure 17. Graphs showing area within subpopulations A, A1, and A2 (1965-2005) meeting FWS target of more than 90 consecutive dry days within the breeding season (Mar 1-Jul 15) for four scenarios (R2F, R2G2, R2H, R1E) and the baseline condition (ECB). 23

Figure 18. Graphs showing distribution and kernal probability curve of mean subpopulation water depths during, $A$, early (Mar-Apr) and, $B$, late (May-July 15) breeding seasons, and C, daily difference in water depth between the R2F scenario and baseline condition (ECB), in subpopulation E. [cm, centimeter; CSSS, Cape Sable seaside sparrow].. 24 Figure 19. Graphs showing distribution and kernal probability curve of mean subpopulation water depths during, $A$, early (Mar-Apr) and, $B$, late (May-July 15) breeding seasons, and $C$, daily difference in water depth between the R2G2 scenario and baseline condition (ECB), in subpopulation E. [cm, centimeter; CSSS, Cape Sable seaside sparrow] 25 
Figure 20. Graphs showing distribution and kernal probability curve of mean subpopulation water depths during, $A$, early (Mar-Apr) and, B, late (May-July 15) breeding seasons, and C, daily difference in water depth between the R2H scenario and baseline condition (ECB), in subpopulation E. [cm, centimeter; CSSS, Cape Sable seaside sparrow].. 26 Figure 21. Graphs showing distribution and kernal probability curve of mean subpopulation water depths during, $A$, early (Mar-Apr) and, $B$, late (May-July 15) breeding seasons, and C, daily difference in water depth between the R1E scenario and baseline condition (ECB), in subpopulation E. [cm, centimeter; CSSS, Cape Sable seaside sparrow].. 27 Figure 22. Graphs showing proportion of total area of subpopulation $A(A),. B(B),. C(C),. D(D),. E(E$.$) , and F(F$. meeting U.S. Fish and Wildlife Service target 4-year hydroperiod of 90-210 days for 4 scenarios (R2F, R2G2, R2H, R1E) and the baseline condition (ECB; 1968-2005).

Figure 23. Graphs showing proportion of total area of subpopulation $\mathrm{A}\left(A_{\text {. }}\right), \mathrm{B}(B),. \mathrm{C}(\mathrm{C}),. \mathrm{D}(\mathrm{D}),. \mathrm{E}(E$.$) , and \mathrm{F}(F$. meeting U.S. Fish and Wildlife Service target of > 90 consecutive dry days within the breeding season (Mar 1-Jul 15; 1965 -2005) for 4 scenarios (R2F, R2G2, R2H, R1E) and the baseline condition (ECB). 33

Figure 24. Graphs showing distribution and kernal probability curve of mean subpopulation water depths during, $A$, early (Mar-Apr) and, $B$, late (May-July 15) breeding seasons, and C, daily difference in water depth between the R2F scenario and baseline condition (ECB), in subpopulation B. [cm, centimeter; CSSS, Cape Sable seaside sparrow].. 34

Figure 25. Graphs showing distribution and kernal probability curve of mean subpopulation water depths during, $A$, early (Mar-Apr) and, $B$, late (May-July 15) breeding seasons, and C, daily difference in water depth between the R2G2 scenario and baseline condition (ECB), in subpopulation B. [cm, centimeter; CSSS, Cape Sable seaside sparrow] $\quad 35$

Figure 26. Graphs showing distribution and kernal probability curve of mean subpopulation water depths during, $A$, early (Mar-Apr) and, B, late (May-July 15) breeding seasons, and C, daily difference in water depth between the R2H scenario and baseline condition (ECB), in subpopulation B. [cm, centimeter; CSSS, Cape Sable seaside sparrow].. 36 
Figure 27. Graphs showing distribution and kernal probability curve of mean subpopulation water depths during, $A$, early (Mar-Apr) and, $B$, late (May-July 15) breeding seasons, and C, daily difference in water depth between the R1E scenario and baseline condition (ECB), in subpopulation B. [cm, centimeter; CSSS, Cape Sable seaside sparrow].. 37

Figure 28. Graph showing mean water depth difference (centimeters; $\mathrm{cm}$ ) relative to the existing conditions baseline (ECB) across all breeding seasons (Mar-July 15, 1965-2005) for each scenario within each subpopulation.

Figure 29. Graphs showing distribution and kernal probability curve of mean subpopulation water depths during, $A$, early (Mar-Apr) and, B, late (May-July 15) breeding seasons, and C, daily difference in water depth between the R2F scenario and baseline condition (ECB), in subpopulation F. [cm, centimeter; CSSS, Cape Sable seaside sparrow] .. 39 Figure 30. Graphs showing distribution and kernal probability curve of mean subpopulation water depths during, $A$, early (Mar-Apr) and, $B$, late (May-July 15) breeding seasons, and C, daily difference in water depth between the R2G2 scenario and baseline condition (ECB), in subpopulation F. [cm, centimeter; CSSS, Cape Sable seaside sparrow] $\quad 40$

Figure 31. Graphs showing distribution and kernal probability curve of mean subpopulation water depths during, $A$, early (Mar-Apr) and, B, late (May-July 15) breeding seasons, and C, daily difference in water depth between the R2H scenario and baseline condition (ECB), in subpopulation F. [cm, centimeter; CSSS, Cape Sable seaside sparrow] .. 41 Figure 32. Graphs showing distribution and kernal probability curve of mean subpopulation water depths during, $A$, early (Mar-Apr) and, $B$, late (May-July 15) breeding seasons, and C, daily difference in water depth between the R1E scenario and baseline condition (ECB), in subpopulation F. [cm, centimeter; CSSS, Cape Sable seaside sparrow] .. 42 Figure 33. Graphs showing distribution and kernal probability curve of mean subpopulation water depths during, $A$, early (Mar-Apr) and, $B$, late (May-July 15) breeding seasons, and C, daily difference in water depth between the R2F scenario and baseline condition (ECB), in subpopulation C. [cm, centimeter; CSSS, Cape Sable seaside sparrow].. 43

Figure 34. Graphs showing distribution and kernal probability curve of mean subpopulation water depths during, $A$, early (Mar-Apr) and, $B$, late (May-July 15) breeding seasons, and C, daily difference in water depth between the 
R2G2 scenario and baseline condition (ECB), in subpopulation C. [cm, centimeter; CSSS, Cape Sable seaside sparrow] 44

Figure 35. Graphs showing distribution and kernal probability curve of mean subpopulation water depths during, $A$, early (Mar-Apr) and, $B$, late (May-July 15) breeding seasons, and C, daily difference in water depth between the R2H scenario and baseline condition (ECB), in subpopulation C. [cm, centimeter; CSSS, Cape Sable seaside sparrow].. 45

Figure 36. Graphs showing distribution and kernal probability curve of mean subpopulation water depths during, $A$, early (Mar-Apr) and, B, late (May-July 15) breeding seasons, and C, daily difference in water depth between the R1E scenario and baseline condition (ECB), in subpopulation C. [cm, centimeter; CSSS, Cape Sable seaside sparrow].. 46

Figure 37. Graphs showing distribution and kernal probability curve of mean subpopulation water depths during, $A$, early (Mar-Apr) and, $B$, late (May-July 15) breeding seasons, and C, daily difference in water depth between the R2F scenario and baseline condition (ECB), in subpopulation D. [cm, centimeter; CSSS, Cape Sable seaside sparrow].. 47 Figure 38. Graphs showing distribution and kernal probability curve of mean subpopulation water depths during, $A$, early (Mar-Apr) and, $B$, late (May-July 15) breeding seasons, and C, daily difference in water depth between the R2G2 scenario and baseline condition (ECB), in subpopulation D. [cm, centimeter; CSSS, Cape Sable seaside sparrow] $\quad 48$

Figure 39. Graphs showing distribution and kernal probability curve of mean subpopulation water depths during, $A$, early (Mar-Apr) and, $B$, late (May-July 15) breeding seasons, and C, daily difference in water depth between the R2H scenario and baseline condition (ECB), in subpopulation D. [cm, centimeter; CSSS, Cape Sable seaside sparrow].. 49 Figure 40. Graphs showing distribution and kernal probability curve of mean subpopulation water depths during, $A$, early (Mar-Apr) and, $B$, late (May-July 15) breeding seasons, and C, daily difference in water depth between the R1E scenario and baseline condition (ECB), in subpopulation D. [cm, centimeter; CSSS, Cape Sable seaside sparrow].. 50

\section{Tables}

Table 1. Description of water management scenarios modeled by the South Florida Water Management District. 
Table 2. Timespan and description of Cape Sable seaside sparrow variables processed to evaluate scenarios. 52 


\title{
Evaluating Water Management Scenarios To Support Habitat Management for the Cape Sable Seaside Sparrow
}

\author{
By James M. Beerens, Stephanie S. Romañach, and Mark McKelvy
}

\begin{abstract}
The endangered Cape Sable seaside sparrow (Ammodramus maritimus mirabilis) is endemic to south Florida and a key indicator species of marl prairie, a highly diverse freshwater community in the Florida Everglades. Maintenance and creation of suitable habitat is seen as the most important pathway to the persistence of the six existing sparrow subpopulations; however, major uncertainties remain in how to increase suitable habitat within and surrounding these subpopulations, which are vulnerable to environmental stochasticity. Currently, consistently suitable conditions for the Cape Sable seaside sparrow are only present in two of these subpopulations (B and $\mathrm{E}$ ). The water management scenarios evaluated herein were intended to lower water levels and improve habitat conditions in subpopulation A and $\mathrm{D}$, raise water levels to improve habitat conditions in subpopulations $\mathrm{C}$ and $\mathrm{F}$, and minimize impacts to subpopulations B and E. Our objective in this analysis was to compare these scenarios utilizing a set of metrics (short- to long-time scales) that relate habitat suitability to hydrologic conditions. Although hydrologic outputs are similar across scenarios in subpopulation A, scenario R2H reaches the hydroperiod and depth suitability targets more than the other scenarios relative to ECB, while minimizing negative consequences to subpopulation E. However, although R2H hydroperiods are longer than those for ECB during the wet season in subpopulations $\mathrm{C}$ and $\mathrm{F}$, depths during the breeding season are predicted to decrease in suitability (less than $-50 \mathrm{~cm}$ ) relative to existing conditions.
\end{abstract}

\section{Introduction}

The Cape Sable seaside sparrow (Ammodramus maritimus mirabilis; hereafter "sparrow” or "CSSS") is endemic to south Florida and a key indicator species of marl prairie, a highly diverse freshwater community in the Florida Everglades. Marl prairie habitat is shaped by distinct flooding, drying, and fire intervals, which maintain periphyton production (Gaiser and others, 2011), vegetation composition (Sah and others, 2011), and habitat structure for wildlife (Lockwood and others, 2003). Historically, the location of marl prairie patches in the Everglades landscape shifted in response to changing hydroclimatic conditions; however, habitat loss and hydrologic alteration now restrict the range of this habitat, thereby narrowing the sparrow's range and increasing their sensitivity to changing hydropatterns. As a result, sparrow numbers have declined as much as 60 percent range-wide since 1992 (Curnutt and others, 1998, Nott and others, 1998). Currently, the sparrow is restricted to the marl prairies of Everglades National Park (ENP) and Big Cypress National Preserve (Lockwood and others, 1997). Because this nonmigratory bird is restricted in its range, it was among the first species to be listed as endangered by the U.S. Fish and Wildlife Service (FWS) on March 11, 1967 (Pimm and Bass, 2002), and the marl prairies that it resides in are listed as critical habitat.

Maintenance and creation of suitable habitat is seen as the most important pathway to the persistence of the six existing sparrow subpopulations (fig. 1; Sustainable Ecosystems Institute, 2007); however, major uncertainties remain in how to increase suitable habitat within and surrounding these 
subpopulations, which are vulnerable to environmental stochasticity. An improved understanding of the relationships between environmental factors and sparrow habitat suitability is needed to guide restoration efforts.

The 2014 range-wide surveys conducted by ENP indicate the CSSS population (2,720 individuals) fell below a threshold level $(2,915)$, thereby requiring the U.S. Army Corps of Engineers (USACE) to reinitiate consultation in November 2014 on the Everglades Restoration Transition Plan (ERTP), a regional operation plan for water management. The criterion for reinitiating consultation is called the Incidental Take Reinitiation Trigger, which states, "If the annual CSSS population estimate falls below 2,915 sparrows [mean population estimate 2001 to $2009=3,145 \pm 230$ ]), reinitiation of consultation must occur."

As part of the ERTP consultation process, the South Florida Water Management District (SFWMD) produced a set of hydrologic management scenarios (table 1) representing simulations of various operational actions that could be taken at water management structures (fig. 2) to improve conditions for the CSSS. Four scenarios (R2F, R2G2, R2H, R1E) and an existing condition baseline (ECB) were generated using 1965-2005 climatological data. Currently, consistently suitable conditions for the sparrow are only present in the most productive subpopulations B and E (Slater and others, 2009). The proposed water management scenarios are designed to lower water levels and improve habitat conditions in subpopulations $\mathrm{A}$ and $\mathrm{D}$, raise water levels to improve habitat conditions in subpopulations C and F, and minimize impacts to subpopulations B and E. Our objective in this analysis was to compare these scenarios utilizing a set of metrics (short- to long-time scales) that relate habitat suitability to hydrologic conditions. The subset of metrics we present here were formulated through discussions with an interagency CSSS group (including representatives from FWS, ENP, and USACE) during a series of meetings in February 2016.

\section{Methods}

Sparrow surveys have been conducted by helicopter visits to sites located on a 1-kilometer (km) grid that encompassed any potential sparrow habitat (Kushlan and Bass, 1983). Observers recorded all sparrows detected over a 7-minute interval within about a 200-meter (m) radius of their set-down location. We used sparrow observations (from helicopter surveys from Mar-Jun, 1992-2015; $\mathrm{n}=$ 13,404) to estimate the spatial distribution of sparrow counts within ENP.

Using ArcMap (v. 10.3; ESRI, 2011), survey data from 2000-15 were overlain on water-depth data collected from the Everglades Depth Estimation Network (EDEN) on the same dates. EDEN is a nearly real-time integrated network that consists of over 240 water-level gages and provides daily waterdepth data (within $\pm 5 \mathrm{~cm}$ ) in 400×400-m grid cells (Liu and others, 2009) and empirically accounts for evapotranspiration, rainfall, and sheetflow (Telis, 2006). From the EDEN data, a set of hydrologic variables were calculated over multiple temporal scales as proxies for landscape processes that may influence habitat suitability (table 2) and were used to evaluate the scenarios.

Defining Suitable Habitats-The current FWS target for a discontinuous, 1-year hydroperiod suitable for the sparrow is 90-210 days in order to maintain and promote formation of the marl prairie habitat upon which it relies (U.S. Fish and Wildlife Service, 2010). However, a running average of the prior 4-year hydroperiod (HP) may better reflect the temporal scale at which marl prairie habitat is created and sustained (Ross and others, 2006). Interannual variability in hydroperiod at a site (defined as one standard deviation around the mean 4-year hydroperiod [HP SD]) reveals additional information about hydrologic conditions potentially affecting sparrow habitat. We calculated quantiles of sparrow observations over the entire period of record for HP and HP SD (table 2) and defined suitable ranges as between the 25-75-percent quantile (middle 50 percent of sparrow observations). From these ranges, we 
mapped hydroperiod duration and variability across the landscape for each SFWMD Regional Simulation Model (RSM) scenario (mean; 1968-2005). Here we assumed that relationships defined using EDEN data can be transferred to the RSM. Although both methods have been independently validated, no crosswalk currently exists to explicitly link them. We also mapped the mean change in hydroperiod of each scenario relative to the ECB. In addition, we calculated consecutive dry days (CDD) within the breeding season, a metric the FWS uses to indicate habitat conditions that allow for multiple breeding attempts in one season (greater than 90 days; U.S. Fish and Wildlife Service, in press).

We examined the geographic proportion of each subpopulation that met the FWS targets for HP and CDD (table 2) for each scenario year 1968-2005 and 1965-2005, respectively. Across this time span, we then identified the frequency of years for each scenario in which 40 percent of each subpopulation met the targets (a defined FWS goal; U.S. Fish and Wildlife Service, in press).

Defining New Subpopulation Boundaries-The historic location boundaries of the six CSSS subpopulations (fig. 1) were delineated by the U.S. Fish and Wildlife Service (2007). We mapped the frequency (from 2000-15) that each EDEN cell met both the HP and HP SD criteria (see Results) to identify "hydroperiod suitable" areas that may lie outside of these sparrow subpopulation boundaries. We classified cells around subpopulation A that met both hydroperiod criteria greater than 25 percent of years as additional hydroperiod suitable areas and included these cells in newly defined boundaries for the subpopulation (A1 and A2, fig. 2). The FWS has identified a target size of 24,000 acres of habitat that should meet their hydrologic metrics (greater than 90 consecutive dry days and 90-210 days of discontinuous hydroperiod) within the expanded boundary (U.S. Fish and Wildlife Service, in press). Using our newly defined boundaries, we calculated the area of subpopulation A (1968-2005 for HP, 1965-2005 for CDD) meeting the targets to determine the number of years for each scenario in which the area exceeded 24,000 acres.

Associating Mean Subpopulation Water Depth with Sparrow Abundance-Sparrow survey data from 2000-15 were used to identify the number of sparrows detected in a given EDEN cell on a given day. The mean water depths for the subpopulation area containing this cell were then averaged over all detections. We then plotted the average water depth value for the subpopulation area against the sum of bird occurrences over the 16-year time period to determine mean water depths associated with increased sparrow abundance in the subpopulation area. The mean depths corresponding to highest abundance (2000-15) were defined as the most suitable. These depth values were used to evaluate the shifts in depth distribution observed between the ECB and each scenario. To compare the baseline to each scenario, kernel probability distribution curves were computed that represent the water-depth histograms. The kernel distribution curve is computed by summing the component smoothing functions for each data value to produce a smooth, continuous probability curve (SAS Institute, 2010). A scenario was considered more suitable than the ECB if there was an increased frequency of "suitable” breeding season water depths.

\section{Results}

Across all subpopulations, where 1-3 sparrows were observed, the 25-75-percent quantile range contained sites having an approximate 104- to 203-day HP; where 4-5 sparrows were observed, the middle 50 percent was within an approximate 21- to 218-day HP, and where 6 sparrows were observed, the middle 50 percent was within an approximate 25- to 90-day HP (fig. 3). Subsequent analyses use the FWS-defined metric of 90-210 days to be consistent with the 2010 Biological Opinion for the CSSS (U.S. Fish and Wildlife Service, 2010). Across all bird counts, the middle 50 percent of sparrow observations were located in sites having an HP SD range of about 17-43 days (fig. 4). Based on these 
assessments, the following analyses code a 17-43 day SD as “suitable,” with higher variability decreasing suitability (associated with declining sparrow use; fig. 5). The highest count of sparrows observed at a site (2000-15) occurred at a mean subpopulation water depth of -20 to -50 centimeters (cm) (fig. 6).

Under all scenarios (R2F, R2G2, R2H, R1E) HP decreased near subpopulation A and increased in subpopulation $\mathrm{F}$ compared to that of the ECB. The interannual variability in hydroperiod (HP SD) increased the most under R1E and the least under R2H relative to the ECB (figs. 7-10).

The FWS target of 24,000 acres of suitable hydroperiod (90-210 days) in subpopulation A was only met during periods having below-average rainfall (fig. 11): 1973-79 and 1990-92 (fig. 12; all scenarios). For the R2H scenario, the target was met during an additional 5 years (1980, 1981, 1982, 1989, 2004). Correspondingly, for all scenarios, daily mean water depths decreased relative to the ECB in subpopulation A during both the early (Mar-Apr) and late (May-July 15) breeding season (figs. 13$16 A, B)$. Where a scenario has kernel values that exceed the baseline, there is an increased frequency of depths across that range; higher values from -20 to $-50 \mathrm{~cm}$ show increased "suitability" for the sparrow. Daily differences in mean subpopulation water depth during the breeding season for the 1965 to 2005 period are shown in figures 13C-16C. Negative values indicate a scenario has decreases in mean water depth relative to the baseline, and positive values indicate a scenario has increases in depth. Scenario $\mathrm{R} 2 \mathrm{H}$ produced the greatest number of years in which scenario water depths were lower than ECB water depths in subpopulation A (figs. 13C-16C). The FWS target of consecutive dry days (CDD; > 90 days) was met in 8 years in all scenarios (fig. 17).

Increases in HP affecting the eastern subpopulations were highest in scenario R1E followed by R2F and R2G2, and then R2H (figs. 7-10). The increase in water volume (relative to the ECB) tended to increase water depths in the reverse order of scenarios in subpopulation E, with the least disruption to sparrow breeding depths provided by the R2H scenario (figs. 18-21). The HP target was met by all scenarios during 23 of 38 years (61 percent) and during an additional 3 years under the ECB (fig. 22E), whereas the CDD target was only met during 10 of 40 years (25 percent; all scenarios) and during 1 additional year under R2H (1980; fig. 23E).

For subpopulation B, HP and mean water depths remained more stable, with depths varying \pm 2 $\mathrm{cm}$ or less from the baseline (figs. $24 C-27 C$ ). There were little differences in performance across scenarios in subpopulation B, meeting targets for HP (fig. 22B) and CDD (fig. 23B) during 32 of 38 years (84 percent) and 18 of 40 years (45 percent), respectively.

In subpopulation $\mathrm{F}$, the lengthening of HP relative to ECB was most pronounced in R1E, followed by R2F; the top two performing scenarios during 20 of 38 (53 percent) years (fig. 22F). R2G2 and $\mathrm{R} 2 \mathrm{H}$ performed better than the baseline in approximately half of the scenario years (fig. 22F). Although there was little change in HP between R2H and ECB in subpopulation F, R2H was the only proposed scenario in which mean water depth decreased (mean $-3.22 \mathrm{~cm}$, range -21.29 to $5.56 \mathrm{~cm}$; fig. 28) during the early- and late-season breeding period (figs. 29-32), leading to an increased frequency of unsuitable sparrow subpopulation water depths of less than $-50 \mathrm{~cm}$ (fig. 6). This disparity of results between long- and short-term metrics suggests that despite an extension in hydroperiod, there was a decrease in water-depth suitability within the sparrow's breeding season. The CDD target was met in 13 of 40 years (33 percent) in all scenarios and an additional 1 year in ECB and R2H (1998; fig. 23F).

For subpopulation C, R1E and R2F provided the most benefit relative to ECB during periods considered excessively dry (for example, shorter HP) for the sparrow (for example, 1973-82; fig. 22C). During periods having above average rainfall, R2H provided the best scenario HP outcome during 17 of 38 years (45 percent; fig. 22C) and provided a slight increase in the CDD metric (fig. 23C), exceeding all other scenarios during 25 of 40 years (63 percent). Similar to subpopulation F, water depths 
decreased during the breeding season relative to ECB under $\mathrm{R} 2 \mathrm{H}$ only, contributing to a higher frequency of mean depths within an unsuitable depth range (less than $-50 \mathrm{~cm}$ ) in both the early- and late-breeding season (figs. 33-36). This again demonstrates the value of examining metrics across multiple time scales because increases in the HP metric under R2H would only be considered a positive outcome with corresponding increases in the frequency of breeding season water depths in the suitable range $(-20$ to $-50 \mathrm{~cm})$.

Farthest to the southeast of ENP in subpopulation D, the HP target was only met during the 12 driest years (fig. 11) under all scenarios, during an additional 5 average years under ECB, and during an additional 2 dry years under R2H (fig. 22D). The CDD target was met during 4 years for ECB and an additional 2 years under R2H only (fig 24D). Further, the interannual variation in hydroperiod (HP SD) was substantially reduced with R2H (figs. 7-10C). In scenarios R1E, R2F, and R2G2, the frequency of unsuitable mean water depths (greater than $-20 \mathrm{~cm}$ ) increased in the early breeding season, whereas the frequency of greater depths decreased under R2H (figs. 37-40). In addition, R2H was the only scenario in which there was a consistent reduction in breeding season water depths in most years (fig. 39C).

\section{Summary and Conclusions}

Currently, consistently suitable conditions for the Cape Sable seaside sparrow (Ammodramus maritimus mirabilis) are only present in subpopulations B and E. The water management scenarios evaluated herein were intended to lower water levels and improve habitat conditions in subpopulation A and $\mathrm{D}$, raise water levels to improve habitat conditions in subpopulations $\mathrm{C}$ and $\mathrm{F}$, and minimize impacts to subpopulations B and E. Although hydrologic outputs are similar across scenarios in subpopulation A, scenario R2H reaches the hydroperiod (HP) and depth suitability targets more than the other scenarios relative to ECB, while minimizing negative consequences to subpopulation E. However, although R2H hydroperiods are longer than those for ECB during the wet season in subpopulations $\mathrm{C}$ and $\mathrm{F}$, depths during the breeding season are predicted to decrease in suitability (less than $-50 \mathrm{~cm}$ ) relative to existing conditions.

\section{References Cited}

Curnutt, J.L., Mayer, A.L., Brooks, T.M., Manne, Lisa, Bass, O.L., Jr., Fleming, D.M., Nott, M.P., and S.L. Pimm, S.L., 1998, Population dynamics of the endangered Cape Sable seaside sparrow: Animal Conservation, v. 1, p. 11-20.

Environmental Systems Research Institute (ESRI), 2011, ArcGIS Desktop-Release 10: Redlands, Calif., Environmental Systems Research Institute.

Gaiser, E.E., McCormick, P.V., Hagerthey, S.E., 2011, Landscape patterns of periphyton in the Florida Everglades: Critical Reviews in Environmental Science and Technology, v. 41, supplement 1, p. 92120.

Kushlan, J.A., and Bass, O.L., Jr., 1983, Habitat use and the distribution of the Cape Sable seaside sparrow, in Quay, T.L., Funderburg, J.B., Jr., Lee, D.S., Potter, E.F., and Robbins , C.S., eds., The seaside sparrow-Its biology and management: North Carolina Biological Survey Occasional Paper 1983-5, p. 139-146.

Liu, Z., Volin, J.C., Owen, V.D., Pearlstine, L.G., Allen, J.R., Mazzotti, F.J., and Higer, A.L. 2009, Validation and ecosystem applications of the EDEN water-surface model for the Florida Everglades: Ecohydrology, v. 2, p. 182-194

Lockwood, J.L., Fenn, K.H., Curnutt, J.L., Rosenthal, Deborah, Balent, K.L., and Mayer, A.L., 1997, Life history of the endangered Cape Sable seaside sparrow: Wilson Bulletin, v., 109, p. 720-731. 
Lockwood, J.L., Ross, M.S., and Sah, J.P., 2003, Smoke on the water: the interplay of fire and water flow on Everglades restoration: Frontiers in Ecology and the Environment, v. 1, no. 9, p. 462-468. Nott, M.P., Bass, O.L., Jr., Fleming, D.M., Killeffer, S.E., Fraley, Nancy, Manne, Lisa, Curnutt, J.L, Brooks, T.M., Powel, Robert, and Pimm, S.L., 1998, Water levels, rapid vegetational changes, and the endangered Cape Sable seaside sparrow: Animal Conservation, v. 1, p. 21-29.

Pimm, S.L., and Bass, O.L., Jr., 2002, Range-wide risks to large populations-The Cape Sable sparrow as a case history, in Beissinger, S.R., and McCullough, D.L., eds., Population viability analysis: Chicago, Ill, University of Chicago Press, p. 406-424.

Ross, M.S., Sah, J.P., Ruiz, P.L., Jones, D.T., Cooley, Hillary, Travieso, Rafael, Tobias, Franco, Snyder, J.R., and Hagyari, David, 2006, Effect of hydrologic restoration on the habitat of the Cape Sable seaside sparrow-Annual report to Everglades National Park of 2004-2005, accessed June 17, 2016, at http://digitalcommons.fiu.edu/sercrp/85/.

Sah, J.P., Ross, M.S., Ruiz, P.L., Snyder, J.R., Rodriguez, Diana, and Hilton, W.T., 2011, Cape Sable seaside sparrow habitat monitoring and assessment—2010 Final Report: Southeast Environmental Research Center Research Reports, Paper 96, Miami, Fla., accessed June 17, 2016, at http://digitalcommons.fiu.edu/sercrp/96.

SAS Institute, 2010, SAS 9.3 help and documentation-SGPLOT procedure: Cary, N.C., SAS Institute. Slater, G.L., Boulton, R.L., Jenkins, C.N., Lockwood, J.L., and Pimm, S.L., 2009, Emergency management action plan for the endangered Cape Sable seaside sparrow-Report to the U. S. Fish and Wildlife Service: Mount Vernon, Wash., Ecostudies Institute, 112 p., accessed June 17, 2016, at http://www.ecoinst.org/wp-content/uploads/2014/03/Slater_etal_2009_CSSS_EMAP.pdf.

Sustainable Ecosystems Institute, 2007, Everglades multi-species avian ecology and restoration review: accessed June 17, 2016, at http://www.fws.gov/verobeach/CERPPDFs/Everglades2007FinalReport.pdf.

Telis, P.A., 2006, The Everglades Depth Estimation Network (EDEN) for support of ecological and biological assessments: U.S. Geological Survey Fact Sheet 2006-3087, 4 p.

U.S. Fish and Wildlife Service, 2007, Critical habitat revised designation for the Cape Sable seaside sparrow: Federal Register, v. 72, no. 214, p. 62735-62766.

U.S. Fish and Wildlife Service, 2011, Biological opinion for Everglades Restoration Plan, Phase 1Submitted to US Army Corps of Engineers: Accessed June 17, 2016, at 141.232.10.32/pm/pm_docs/ertp/022511_ertp_v3_app_f.pdf.

U.S. Fish and Wildlife Service, in press, Draft biological opinion for the U.S. Army Corps of Engineers, Everglades Restoration Transition Plan: Vero Beach, Fla., South Florida Ecological Services Office. 


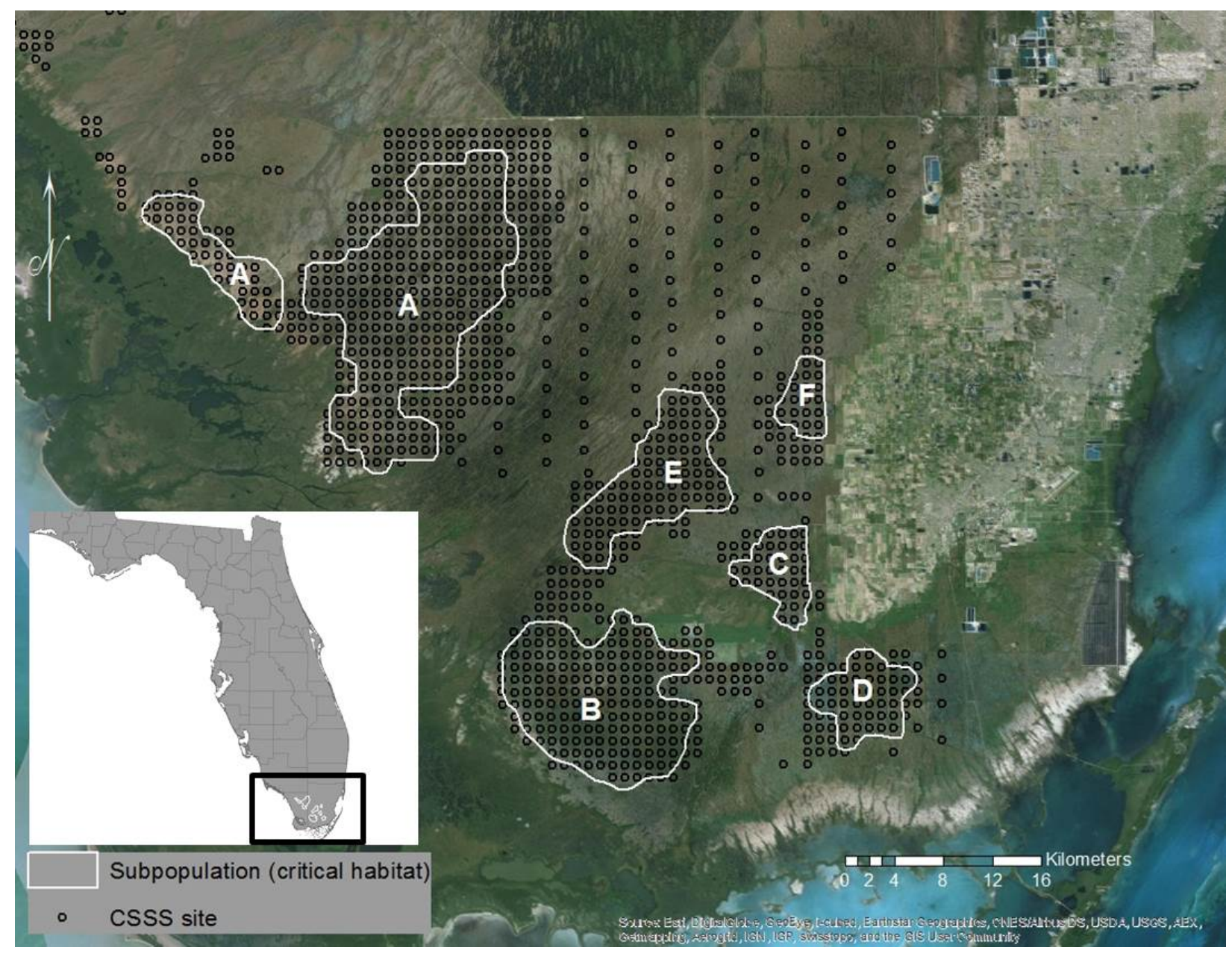

Figure 1. Map of south Florida study area displaying Cape Sable seaside sparrow (CSSS) critical habitat subpopulations and survey sites. 


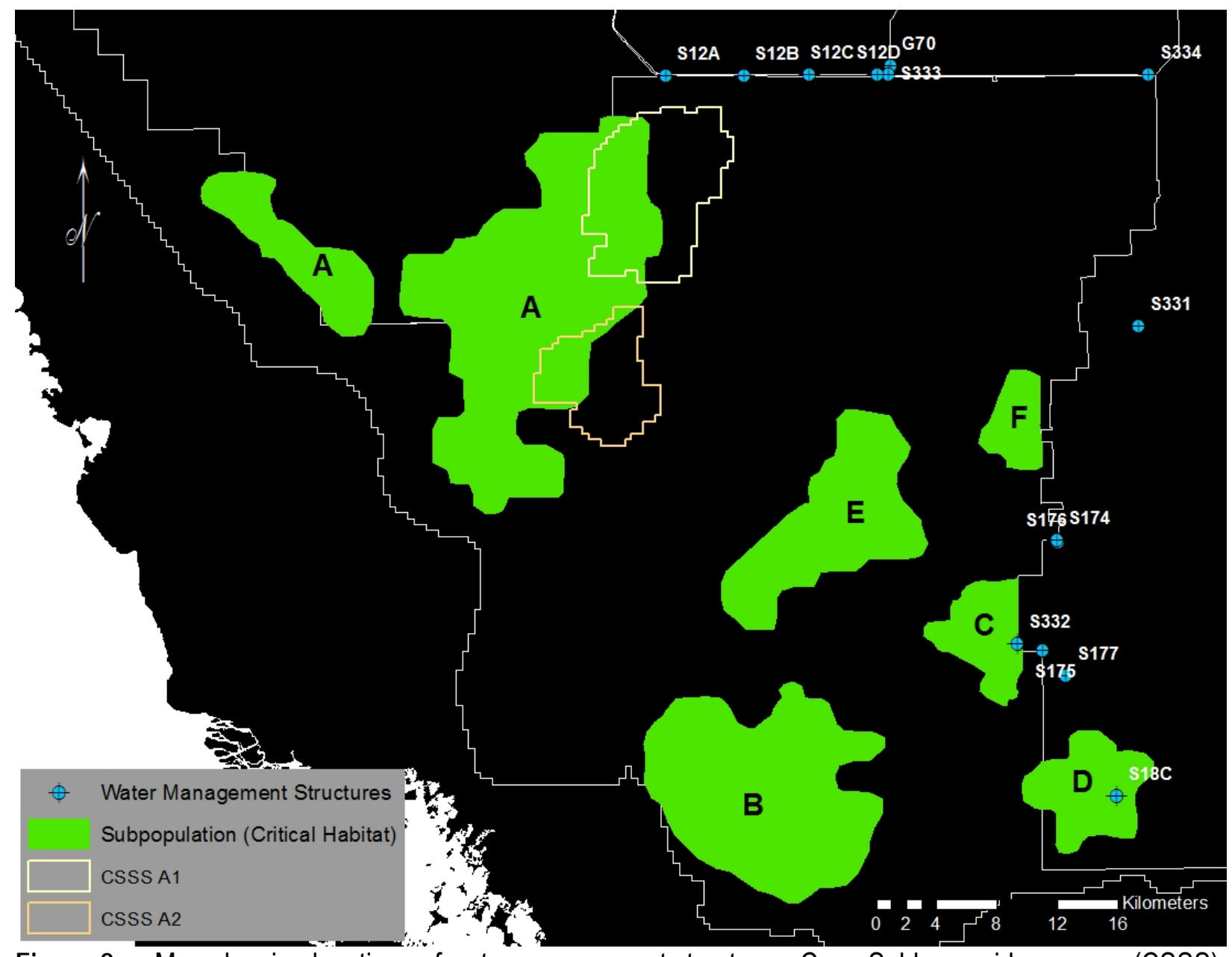

Figure 2. Map showing locations of water management structures, Cape Sable seaside sparrow (CSSS) critical habitat subpopulations, and newly defined boundaries for the subpopulation $A$ ( $A 1$ and $A 2$ ). 


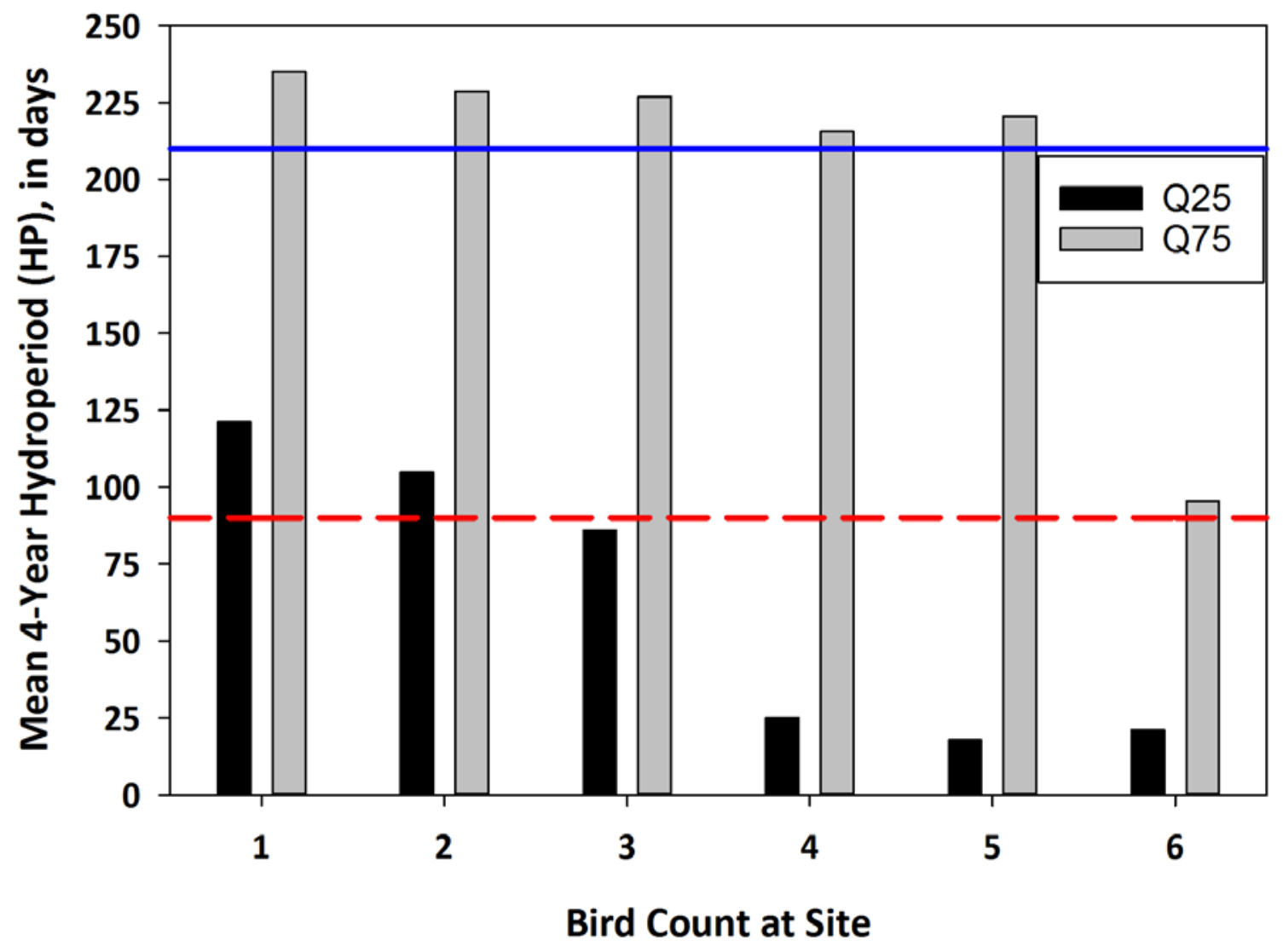

Figure 3. Graph comparing mean 4-year hydroperiod to bird count at study sites. For Cape Sable Seaside sparrow counts of 1-6, 50 percent of sparrow observations (25-75-percent quantile [Q25-Q75]) are located at sites having a 4-year mean hydroperiod (prior to detection) between the black and the grey bars. Everglades Depth Estimation Network (EDEN) hydroperiods of less than 90 days support many (4-6) birds. The area between the dashed red line and solid blue line represents the 90- to 210-day range. 


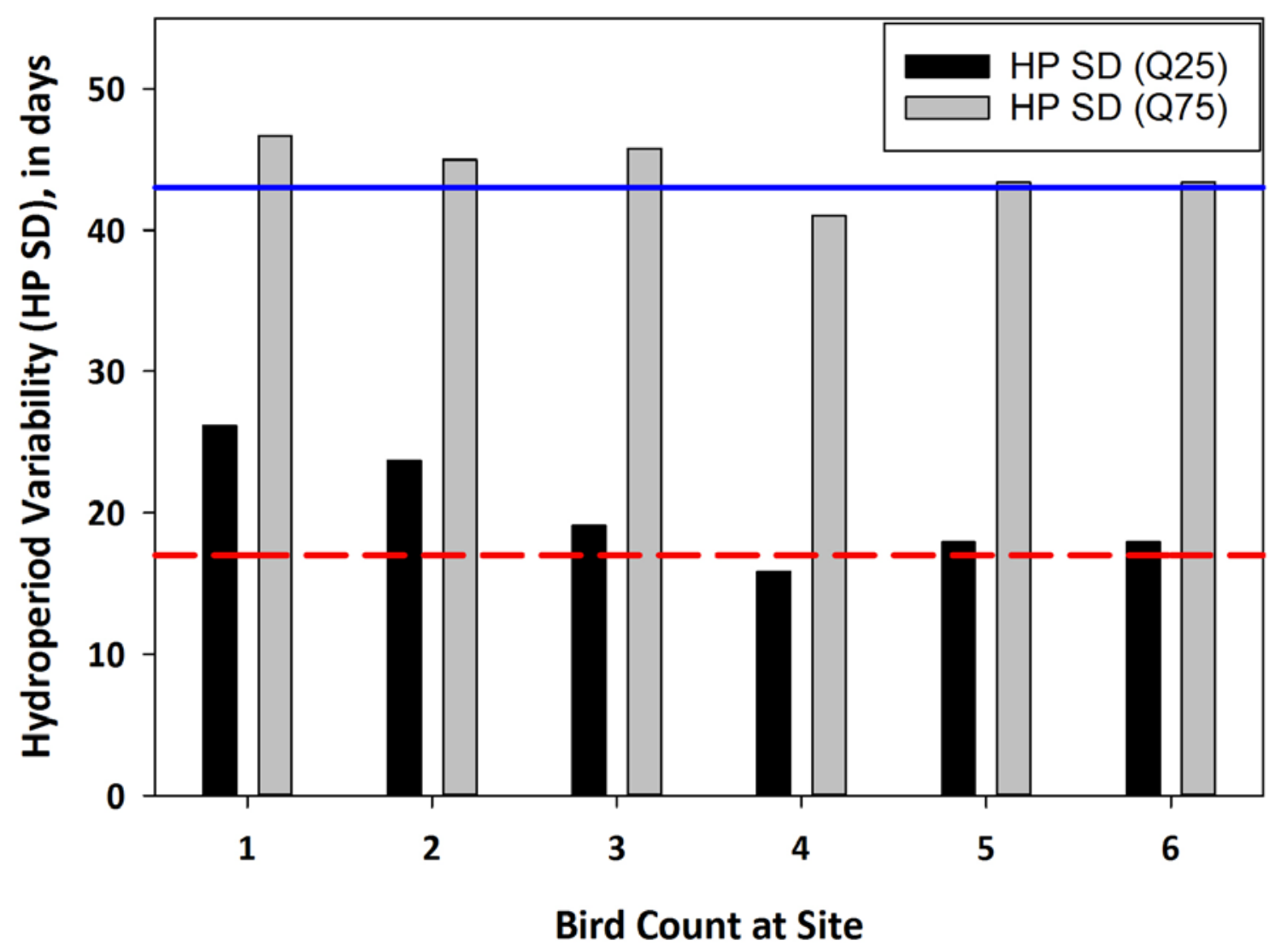

Figure 4. Graph comparing mean 4-year hydroperiod variability (HP SD) to bird count at study sites. Fifty percent of the Cape Sable Seaside sparrows observed (25-75-percent quantile) are located at sites with 4-year hydroperiod variability between the black and the grey bars. The area between the dashed red line and solid blue line represents the 17- to 43-day range. 


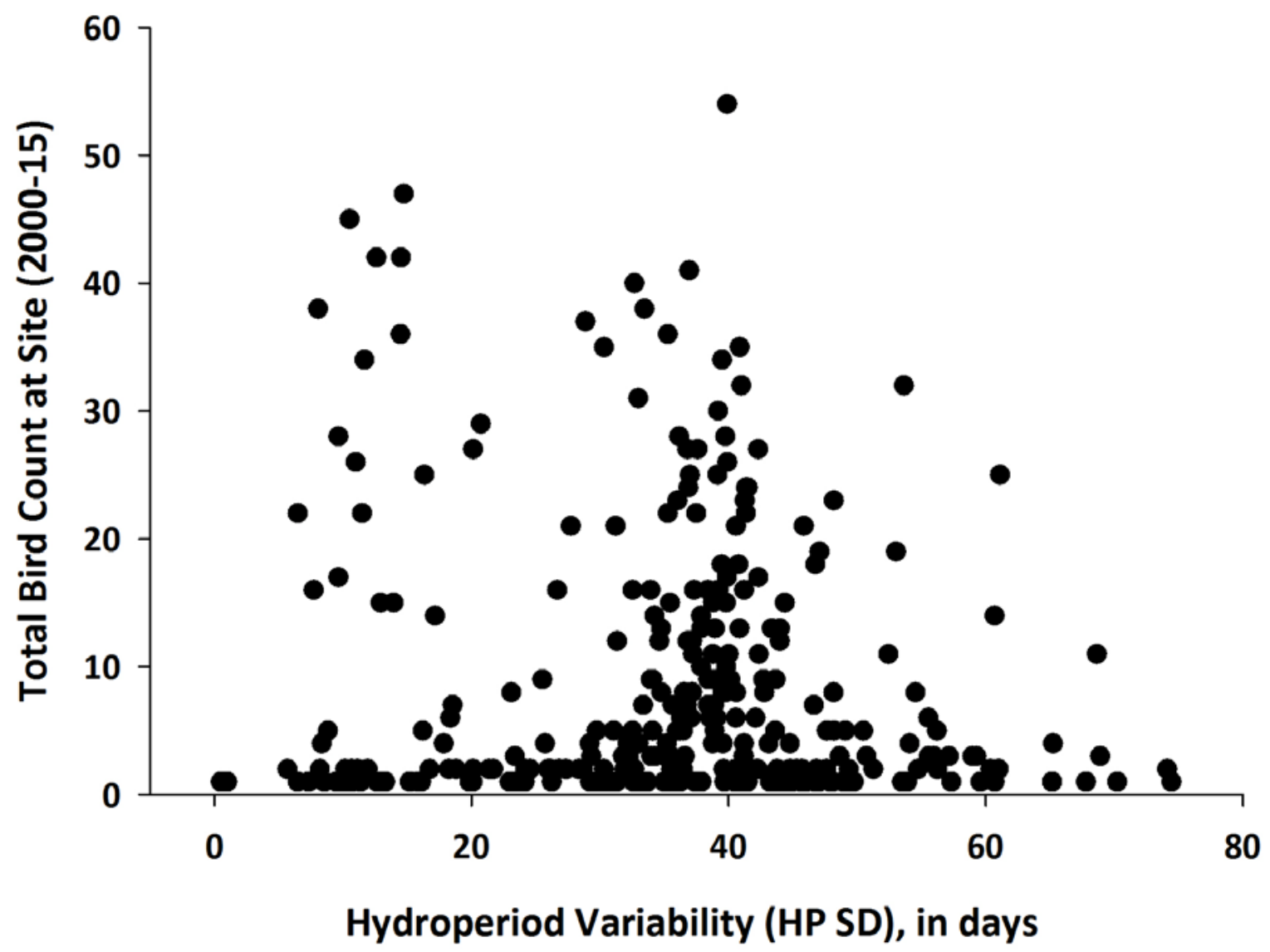

Figure 5. Graph showing the sum of Cape Sable seaside sparrow observations over the period of record (200015 ) at a given site compared to hydroperiod interannual variability (HP SD); declining sparrow abundance is associated with higher interannual variability. 


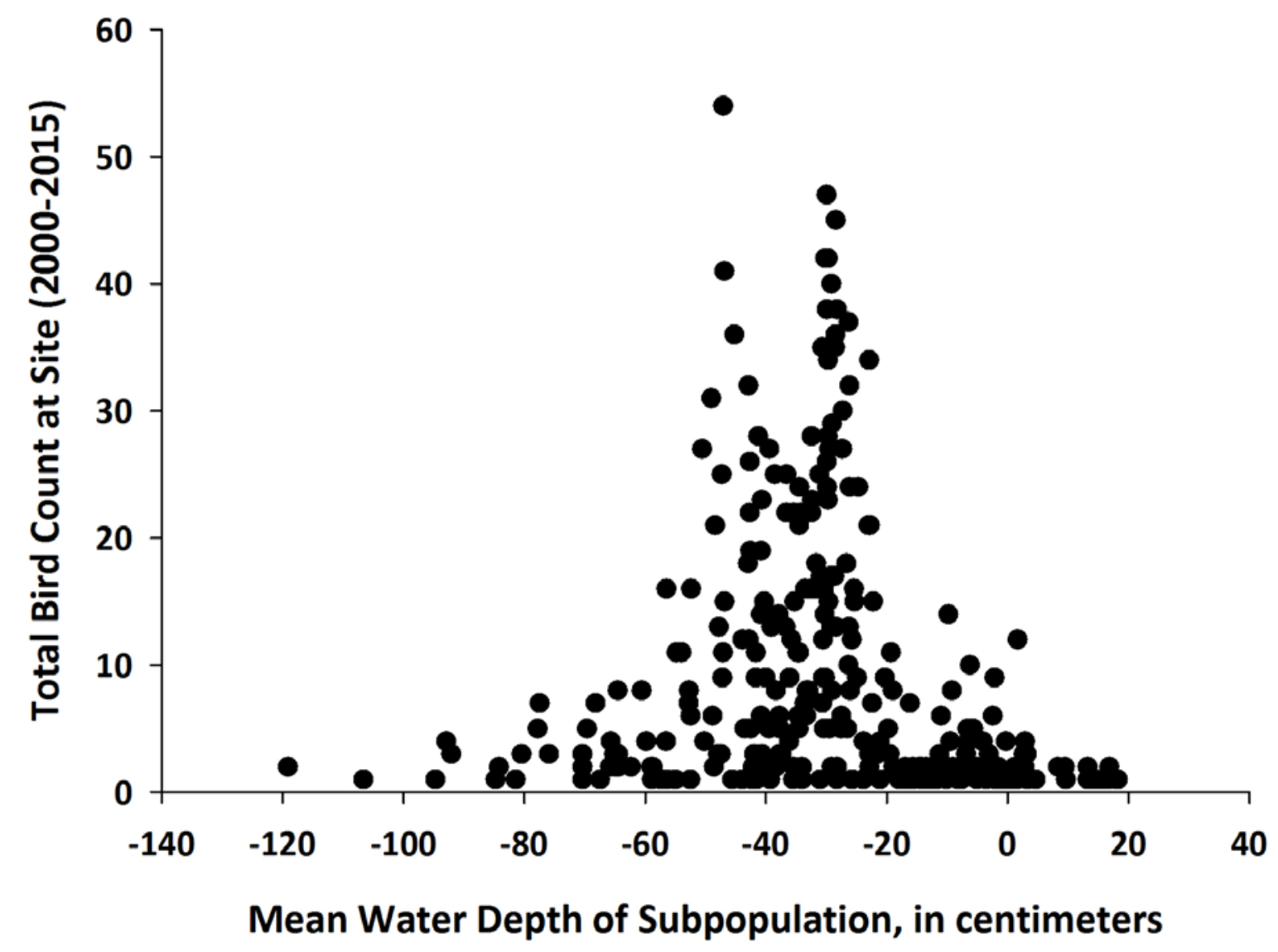

Figure 6. Graph showing the sum of Cape Sable seaside sparrow observations over the period of record (200015 ) at a given site compared to mean subpopulation water depth. Sparrow survey data were used to identify the number of sparrows detected in a given Everglades Depth Estimation Network (EDEN) cell on a given day. The mean water depths for the subpopulation area containing this cell were averaged over all detections, under the assumption that mean depth would converge on suitable values the more a cell was frequented. 
A.

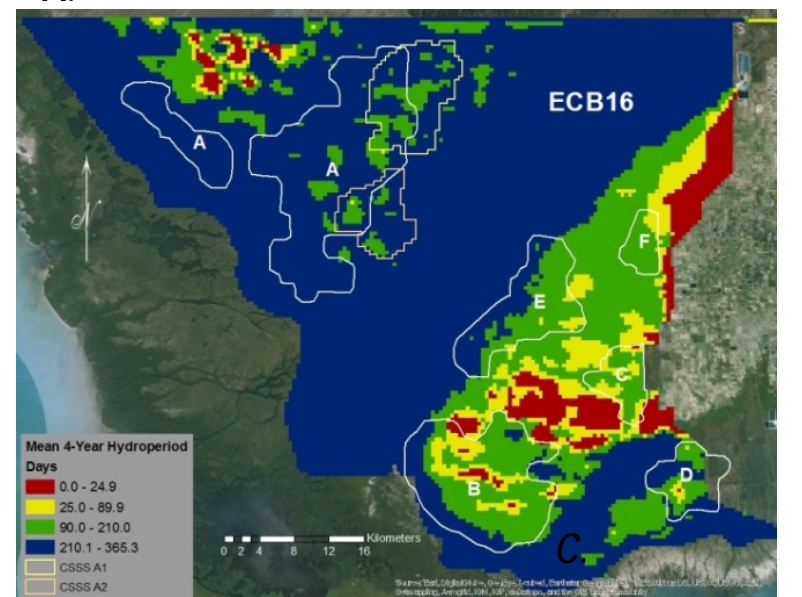

B.

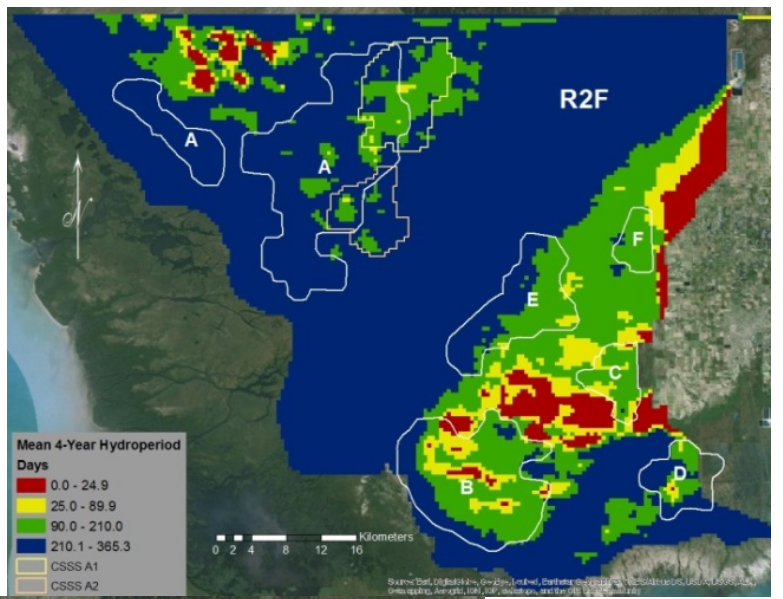

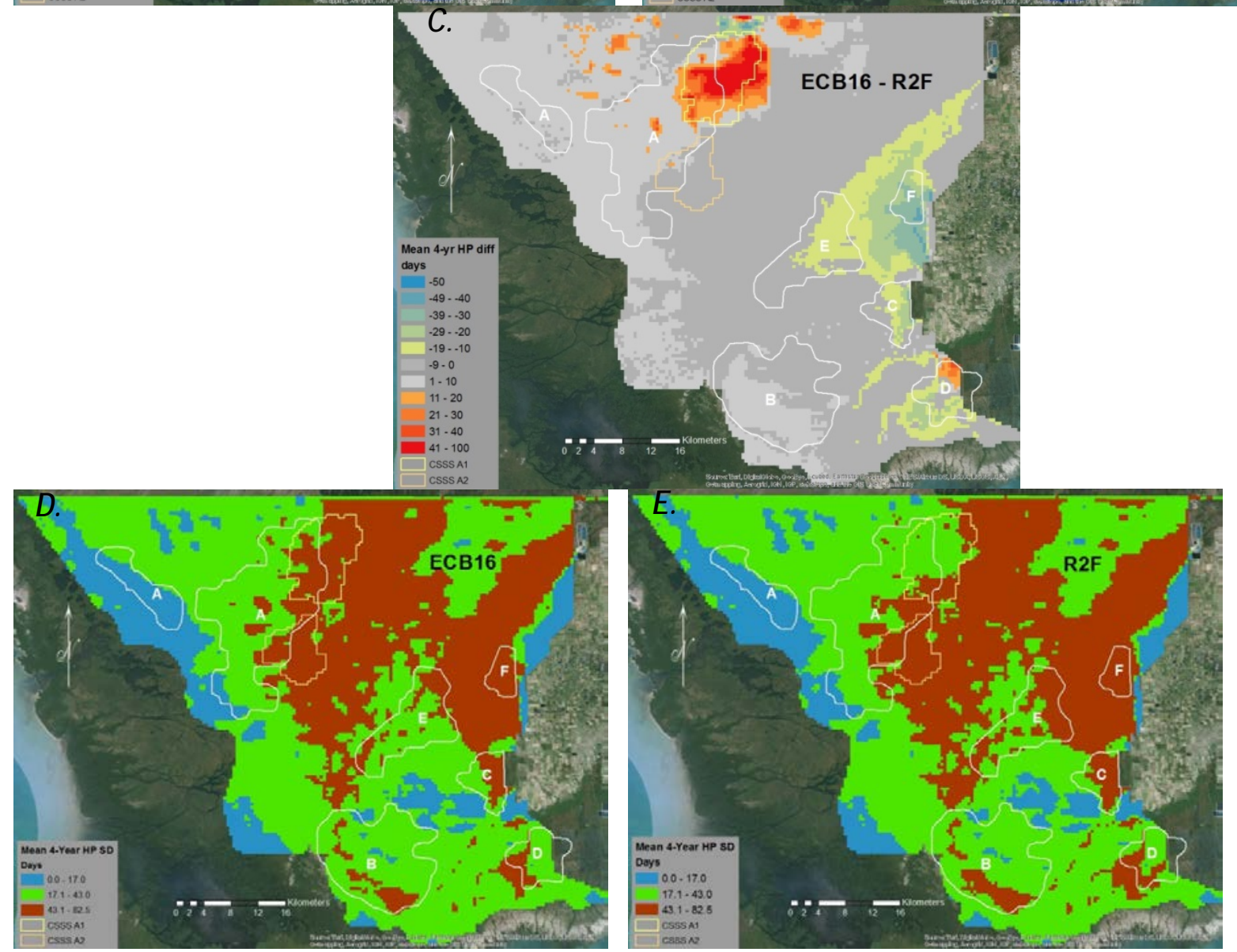

Figure 7. Maps showing, A, mean 4-year hydroperiod of baseline (1968-2004) condition, $B, \mathrm{R} 2 \mathrm{~F}$ scenario, $C$, difference between baseline and scenario, $D$, 4-year hydroperiod variability of baseline condition, and $E$, 4-year hydroperiod variability of scenario condition for Everglades National Park. Boundaries of Cape Sable seaside sparrow (CSSS) subpopulations A-F and populations $\mathrm{A} 1$ and $\mathrm{A} 2$ are denoted on the map. 
A.

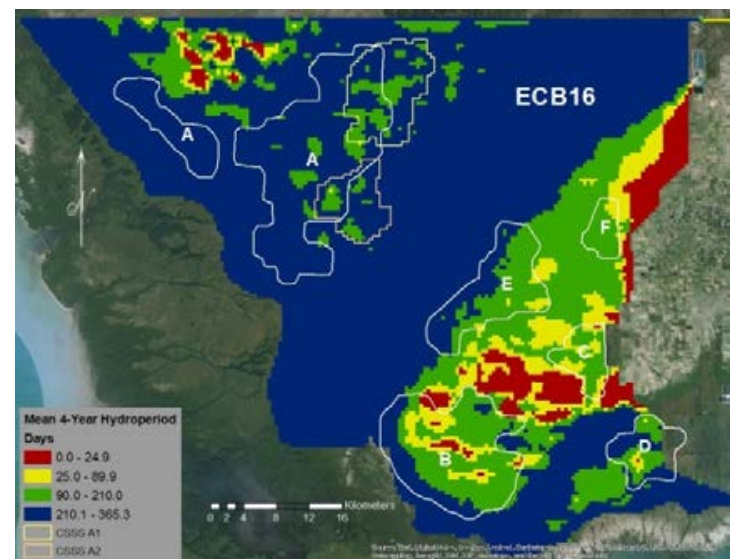

B.
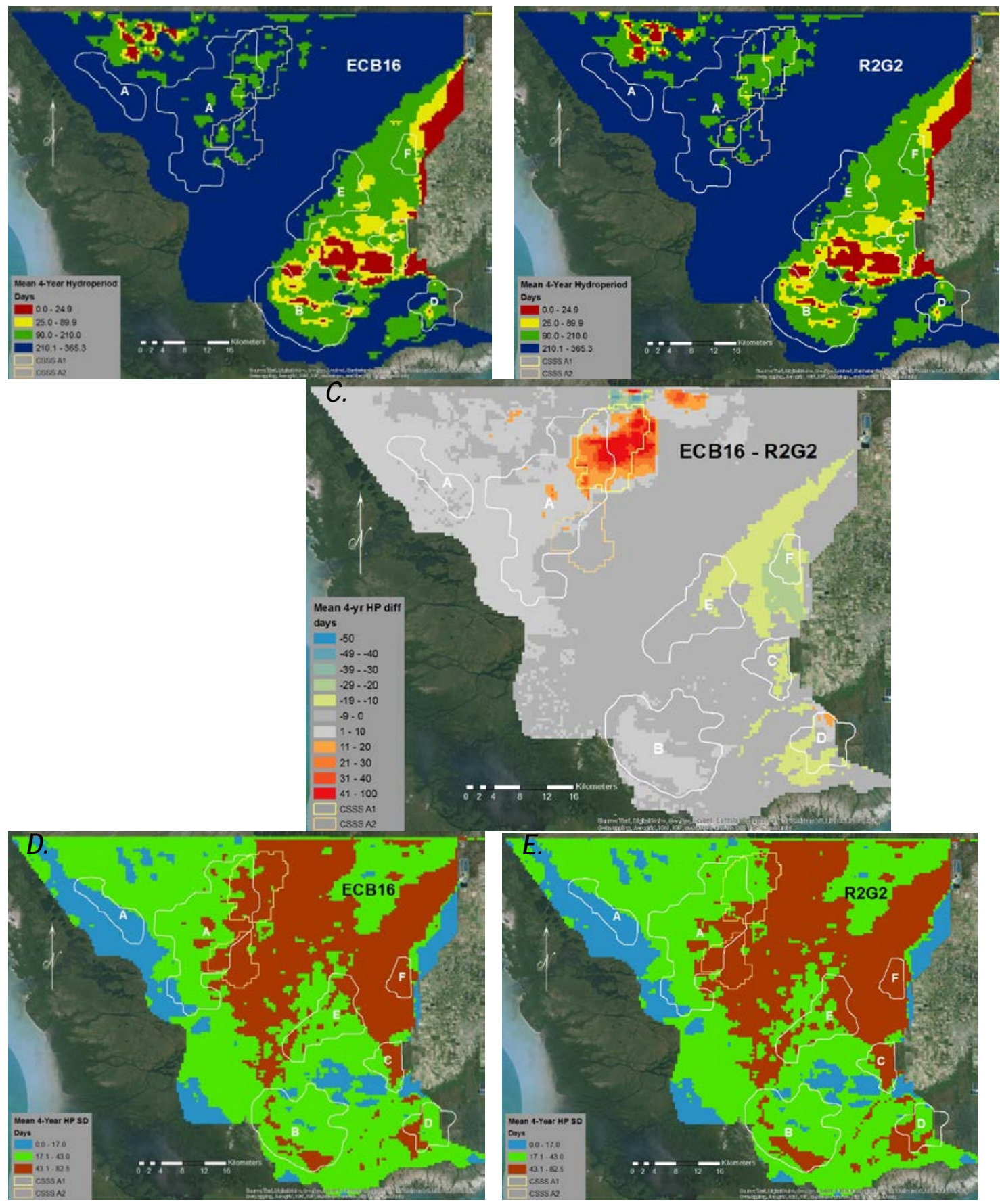

Figure 8. Maps showing, A, mean 4-year hydroperiod of baseline (1968-2004) condition, $B, \mathrm{R} 2 \mathrm{G} 2$ scenario, $C$, difference between baseline and scenario, $D$, 4-year hydroperiod variability of baseline condition, and $E$, 4-year hydroperiod variability of scenario condition for Everglades National Park. Boundaries of Cape Sable seaside sparrow (CSSS) subpopulations A-F and populations A1 and A2 are denoted on the map. 
A.

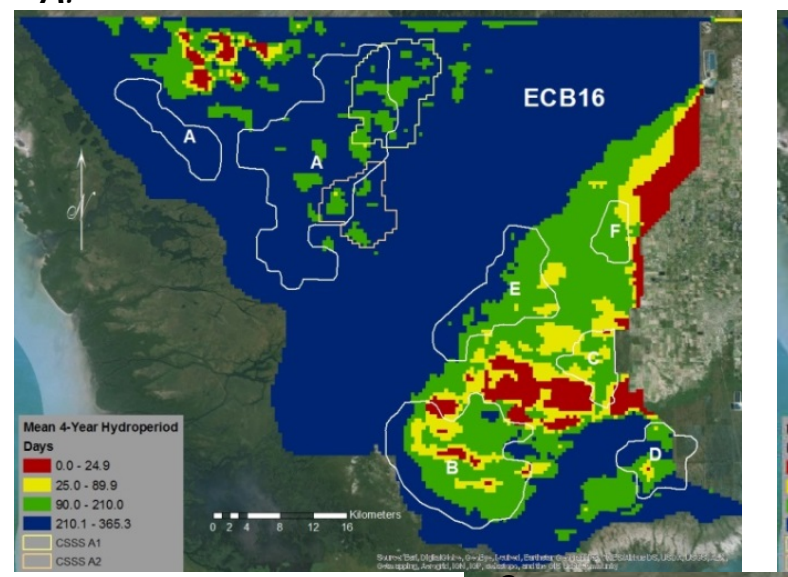

B.

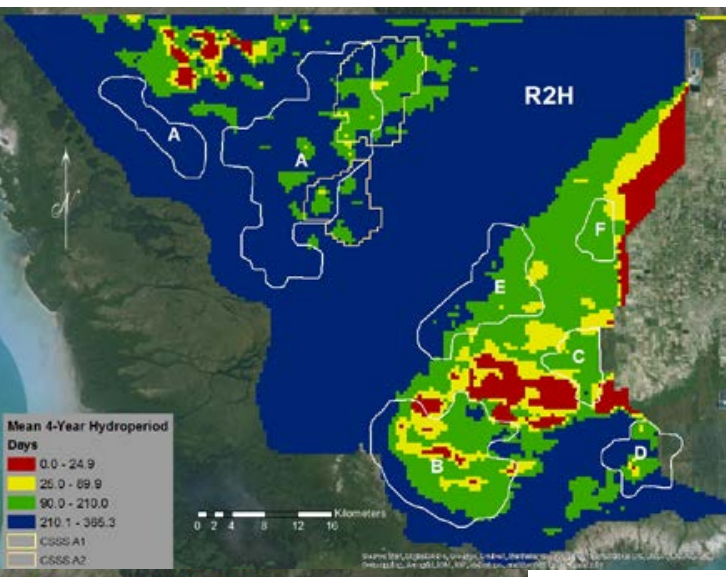

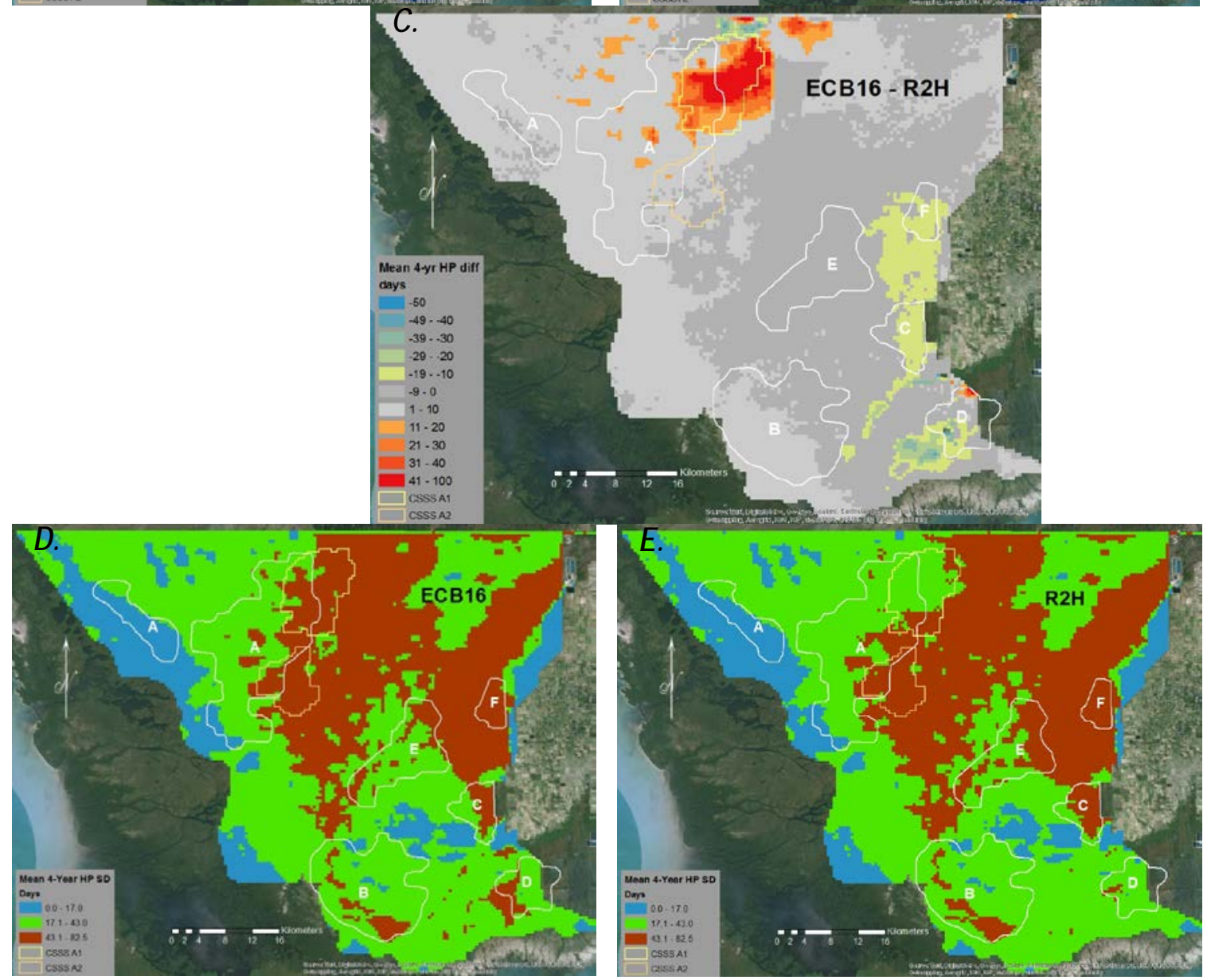

Figure 9. Maps showing, A, mean 4-year hydroperiod of baseline (1968-2004) condition, $B, \mathrm{R} 2 \mathrm{H}$ scenario, $C$, difference between baseline and scenario, $D$, 4-year hydroperiod variability of baseline condition, and $E$, 4-year hydroperiod variability of scenario condition for Everglades National Park. Boundaries of Cape Sable seaside sparrow (CSSS) subpopulations A-F and populations $\mathrm{A} 1$ and $\mathrm{A} 2$ are denoted on the map. 
A.

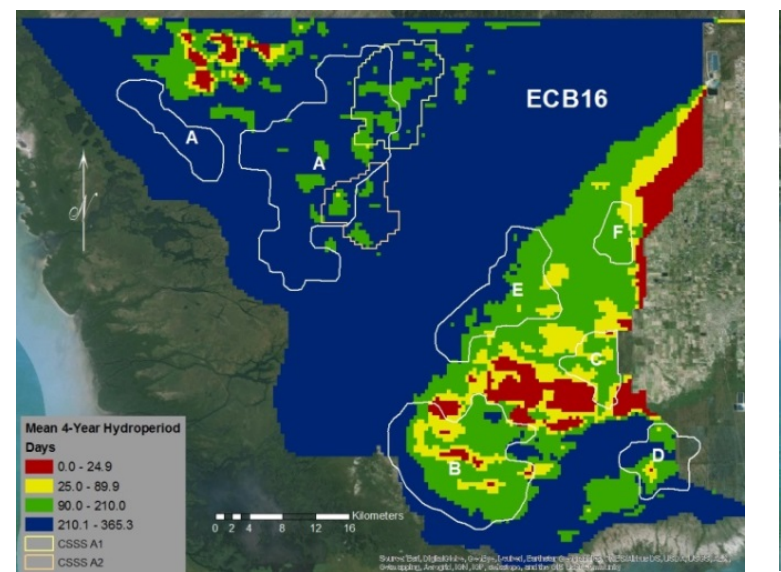

B.

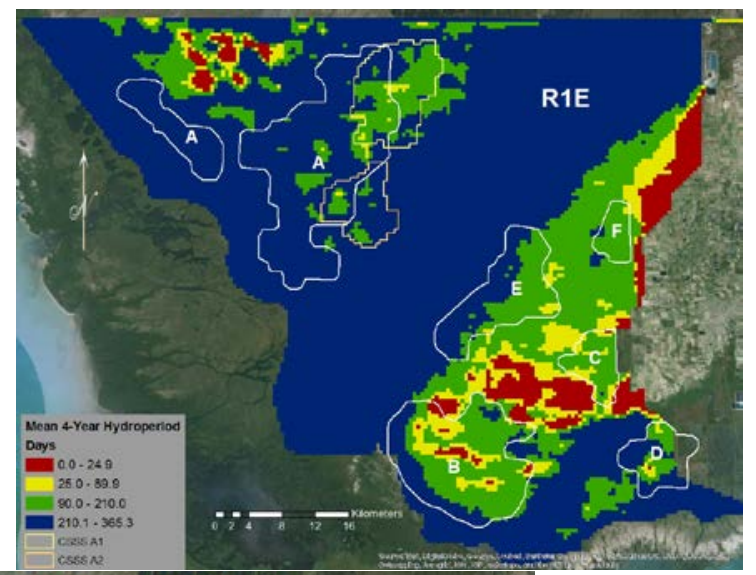

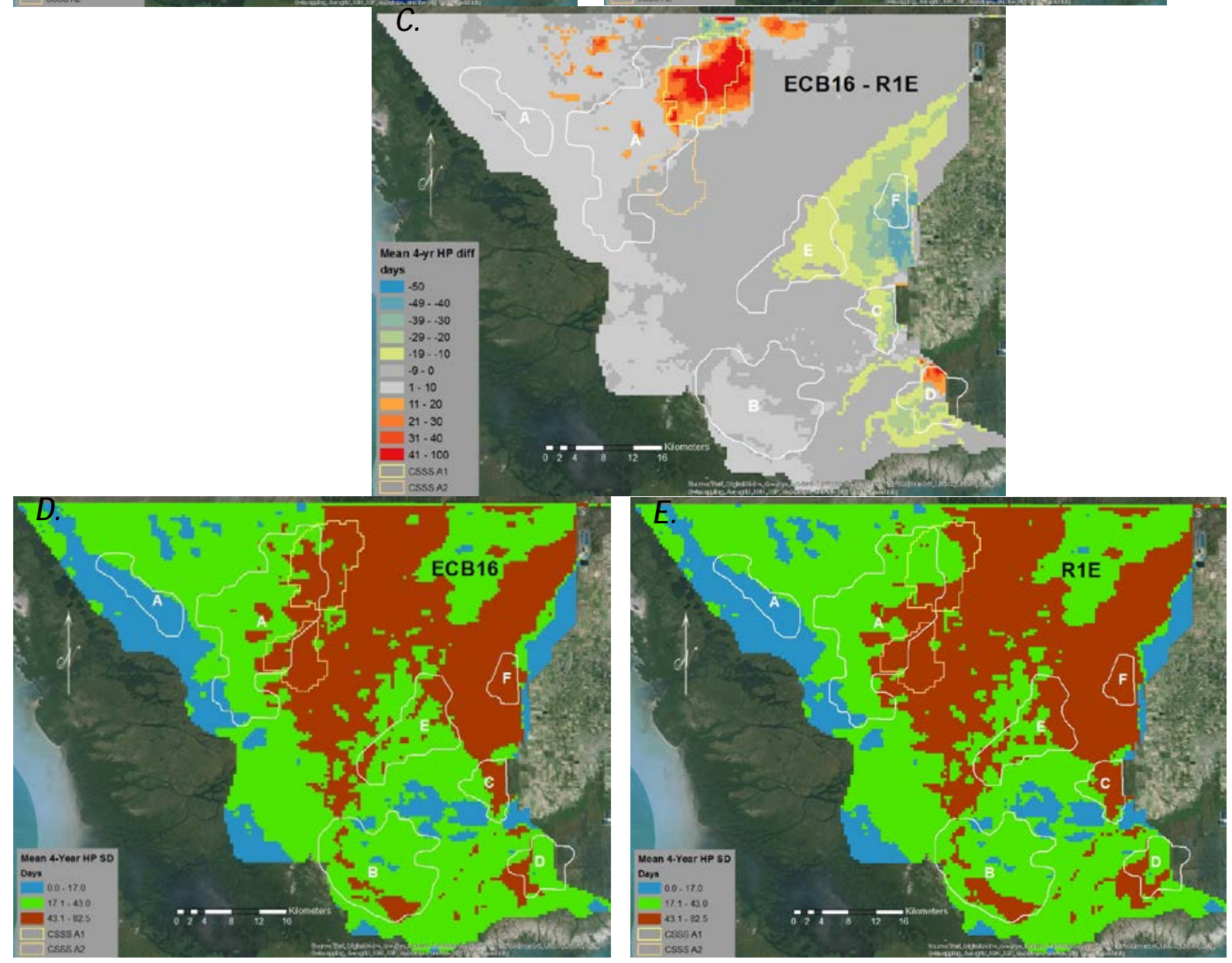

Figure 10. Maps showing, A, mean 4-year hydroperiod of baseline (1968-2004) condition, B, R1E scenario, C, difference between baseline and scenario, $D$, 4-year hydroperiod variability of baseline condition, and $E$, 4-year hydroperiod variability of scenario condition for Everglades National Park. Boundaries of Cape Sable seaside sparrow (CSSS) subpopulations A-F and populations A1 and A2 are denoted on the map. 


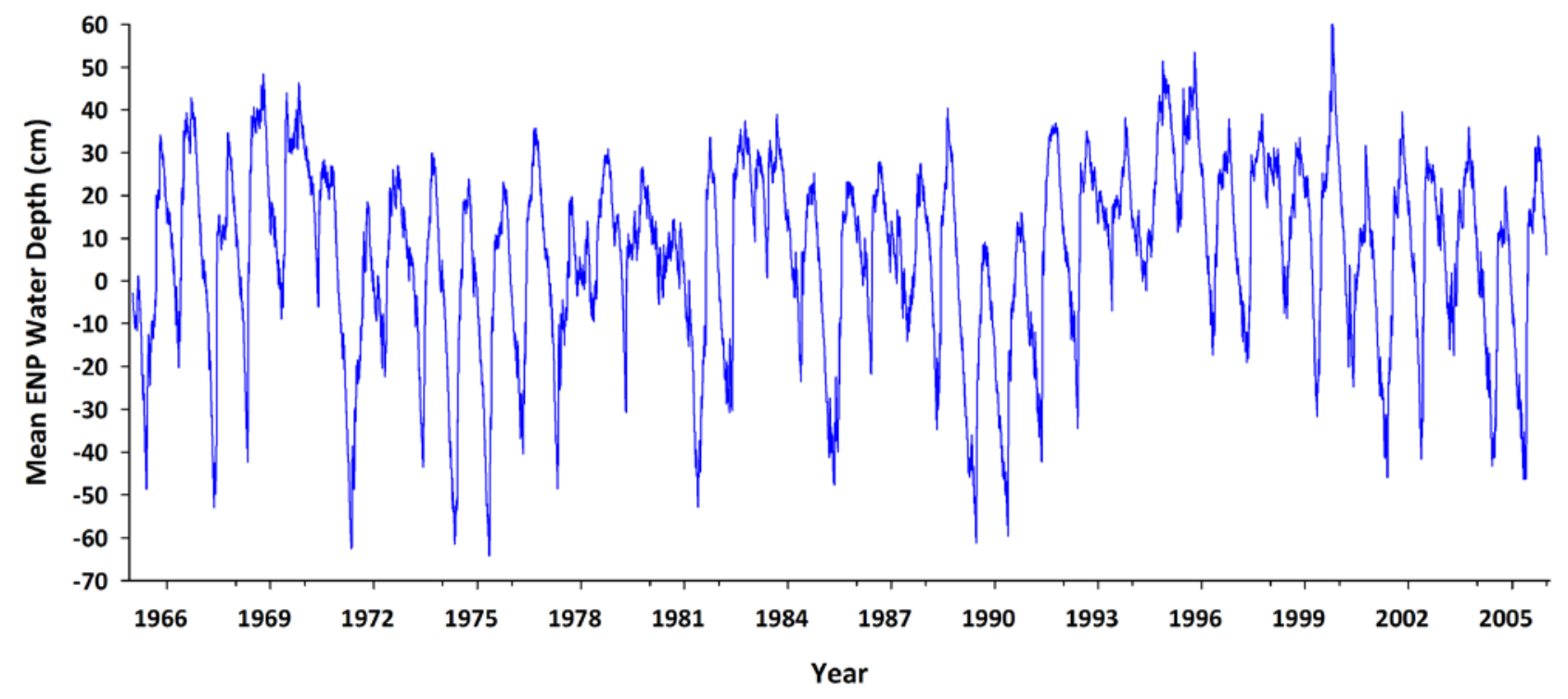

Figure 11. Graph showing mean water depth (1965-2005) for Everglades National Park (ENP) existing conditions baseline (ECB) run produced by the South Florida Water Management District (SFWMD) Regional Simulation Model (RSM). [cm, centimeter] 


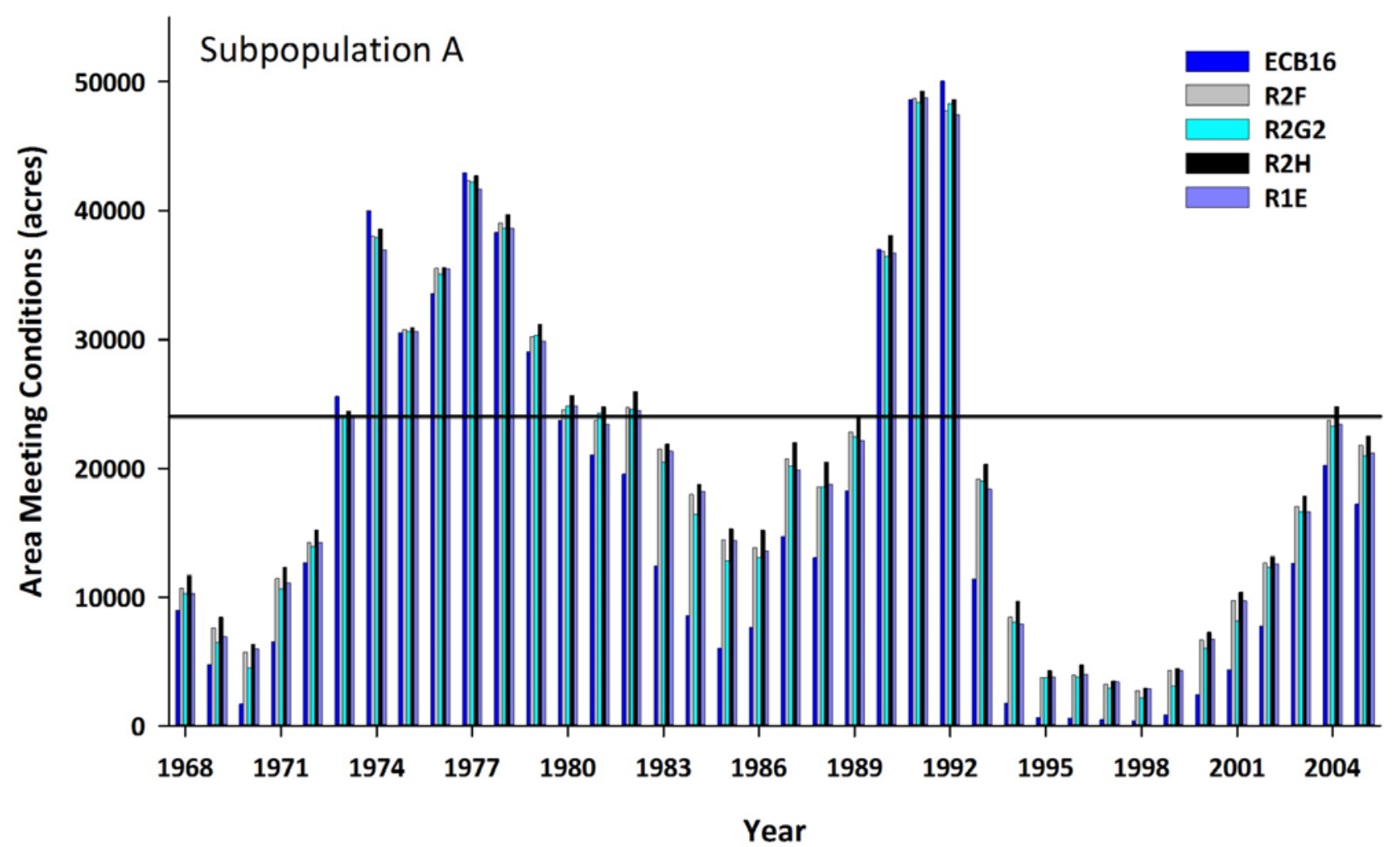

Figure 12. Graph showing area within subpopulations A, A1, and A2 (1968-2005) meeting FWS target 4-year hydroperiod of 90-210 days for 4 scenarios (R2F, R2G2, R2H, R1E) and the baseline condition (ECB). 
A.

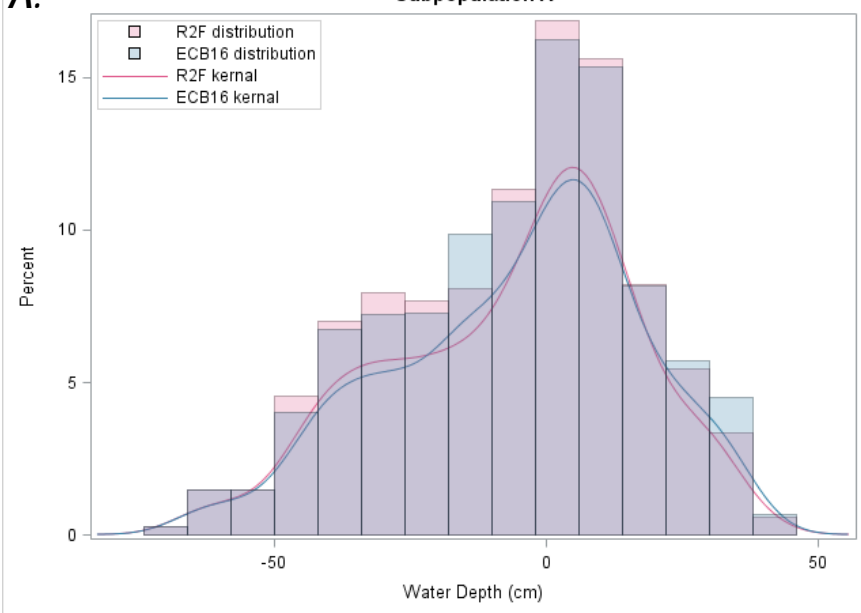

C.

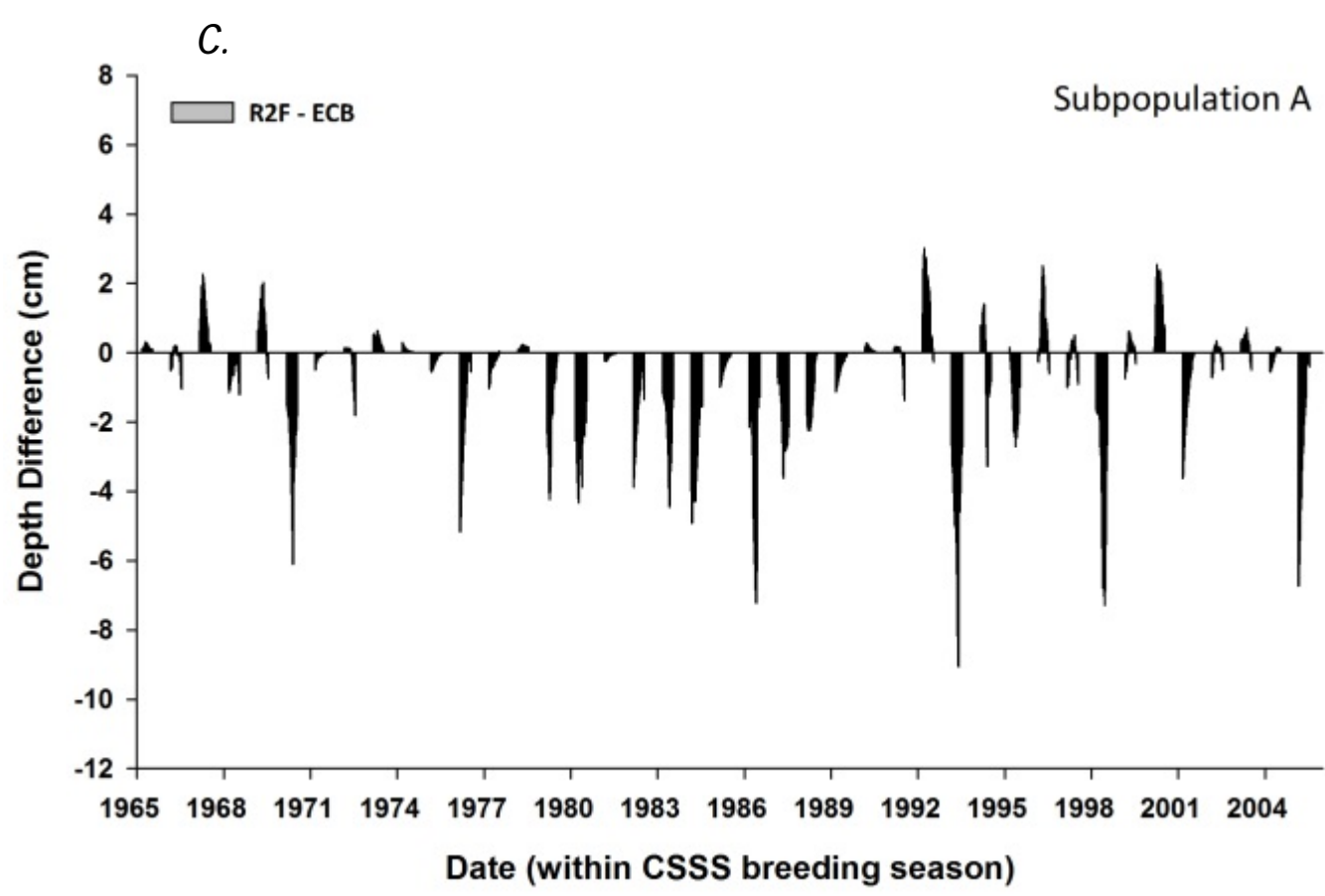

B.

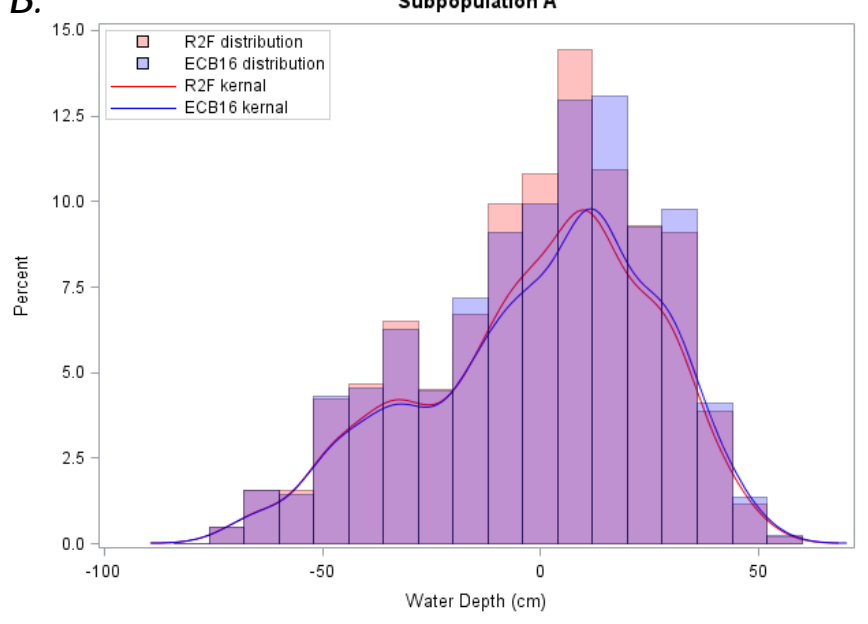

Figure 13. Graphs showing distribution and kernal probability curve of mean subpopulation water depths during, $A$, early (Mar-Apr) and, $B$, late (May-July 15) breeding seasons, and $C$, daily difference for R2F scenario and baseline condition for the R2F scenario, in subpopulation A. [cm, centimeter; CSSS, Cape Sable seaside sparrow] 
A.

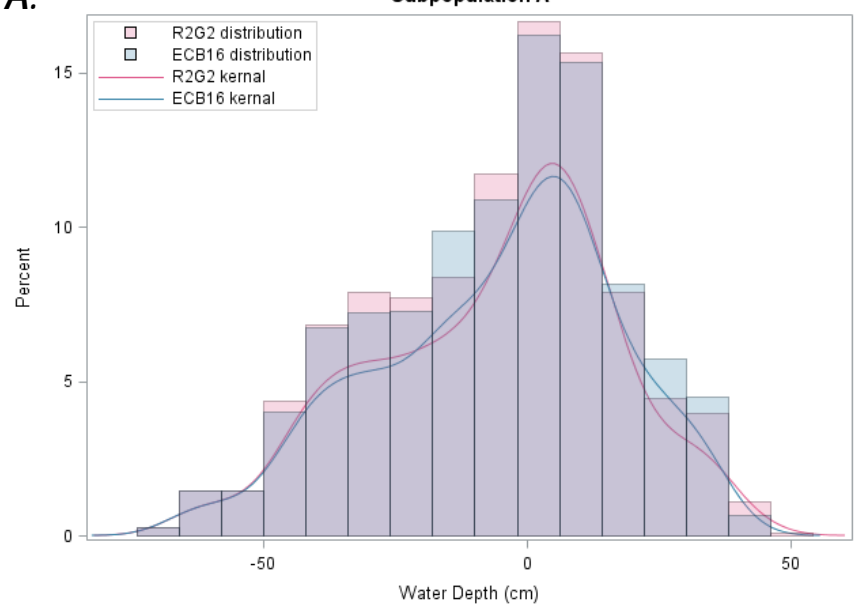

B.

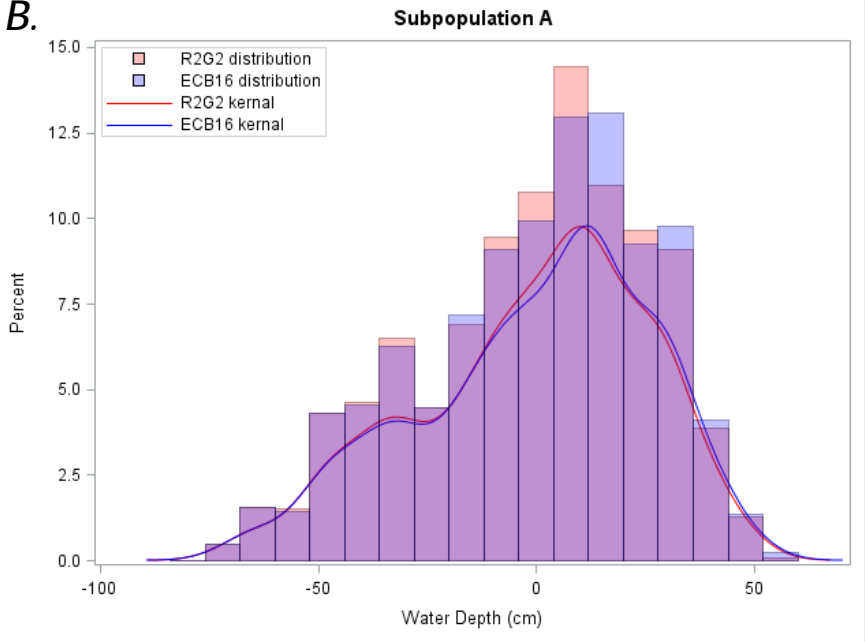

C.

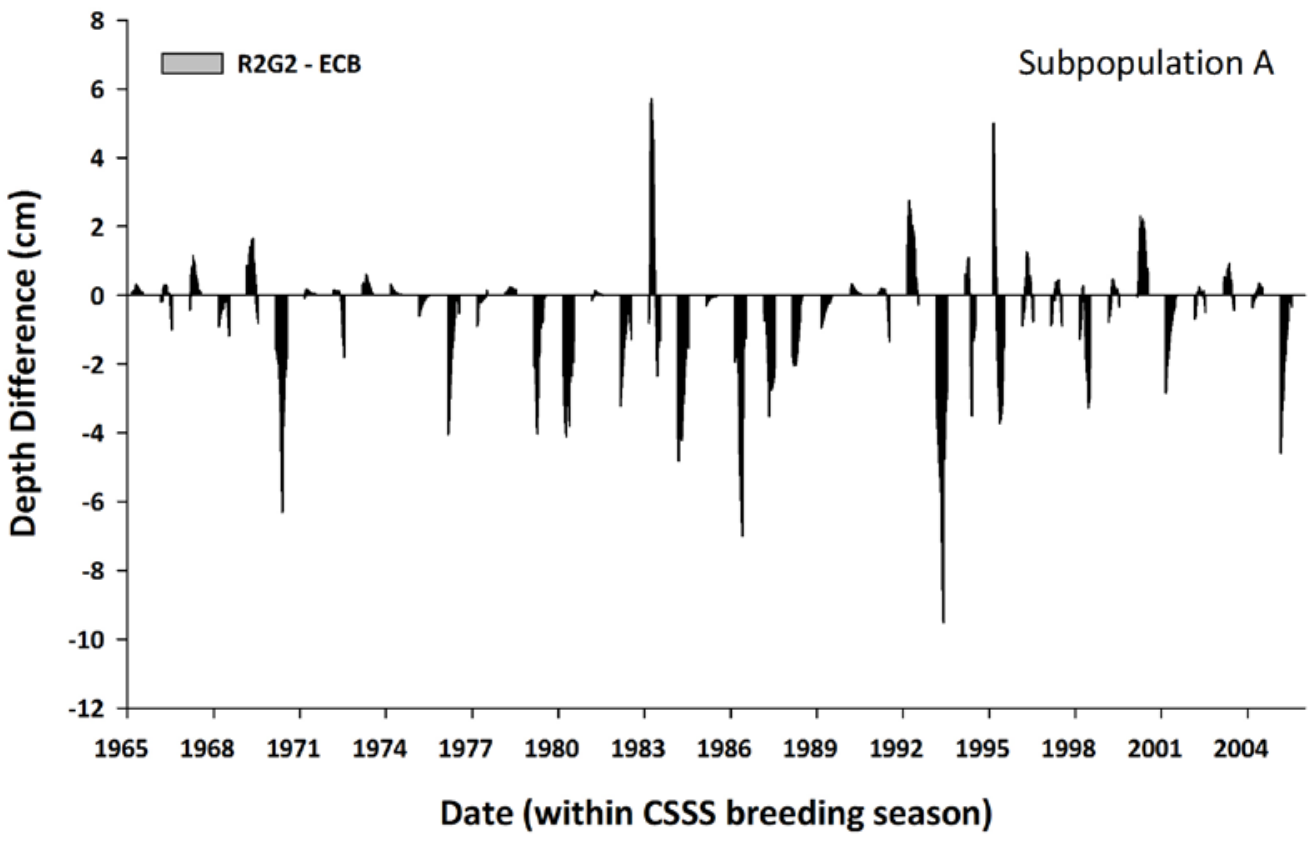

Figure 14. Graphs showing distribution and kernal probability curve of mean subpopulation water depths during, $A$, early (Mar-Apr) and, $B$, late (May-July 15) breeding seasons, and $C$, daily difference in water depth between the R2G2 scenario and baseline condition (ECB), in subpopulation A. [cm, centimeter; CSSS, Cape Sable seaside sparrow] 
A.

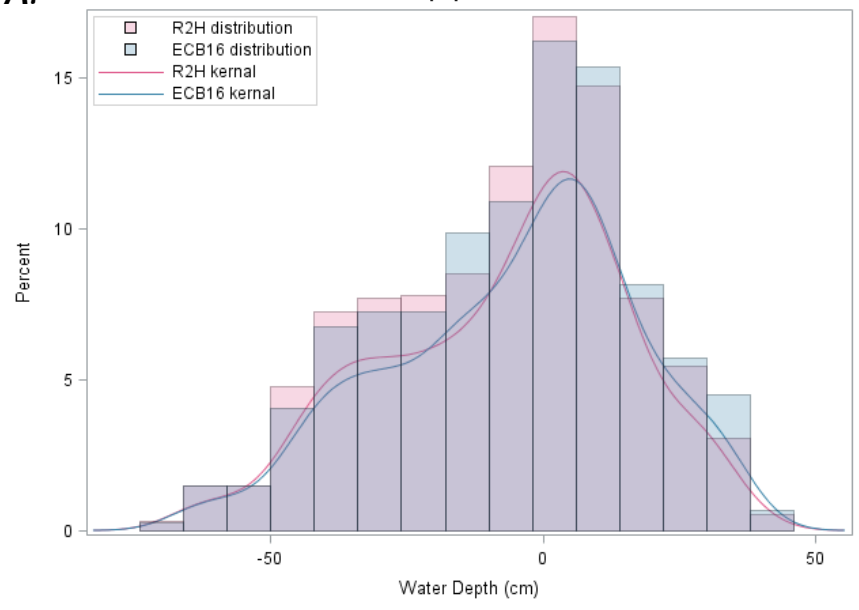

C.

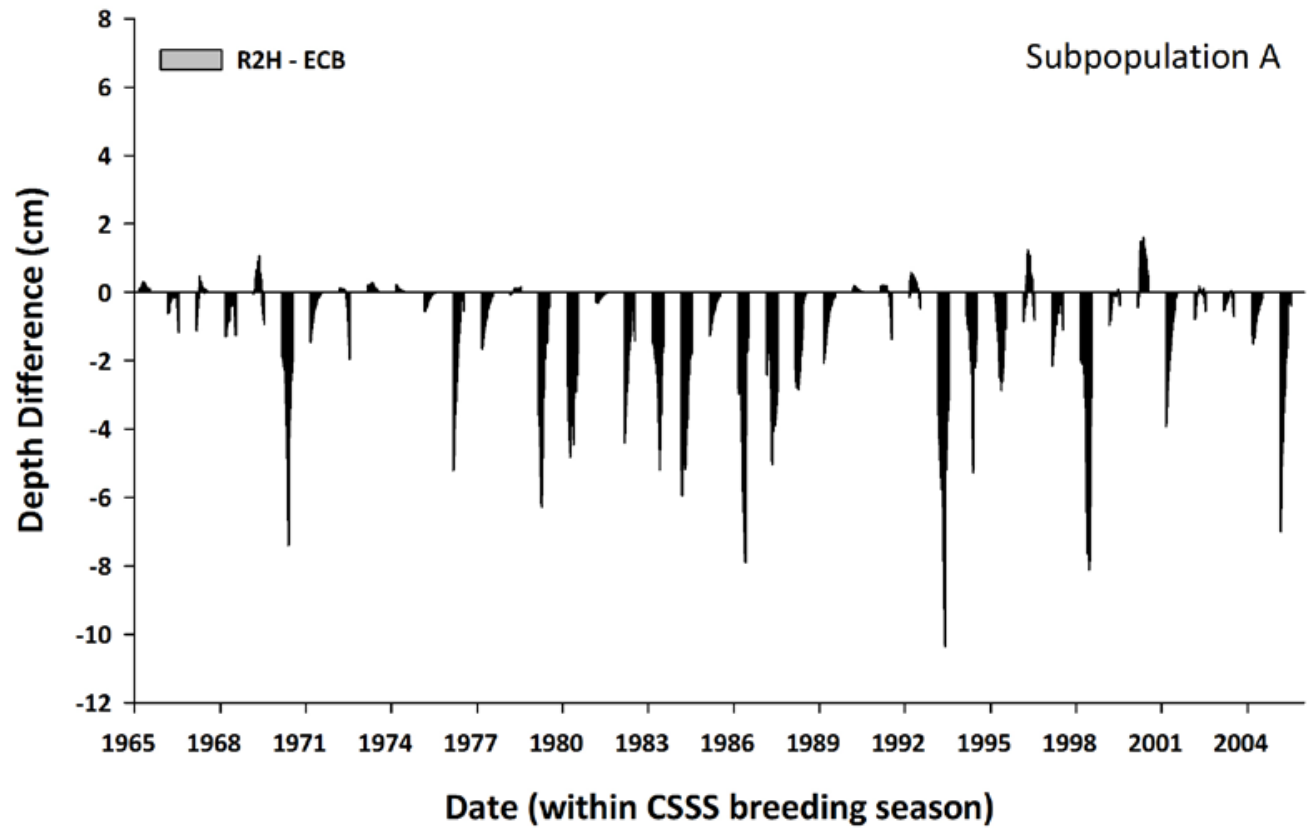

Date (within CSSS breeding season)
B.

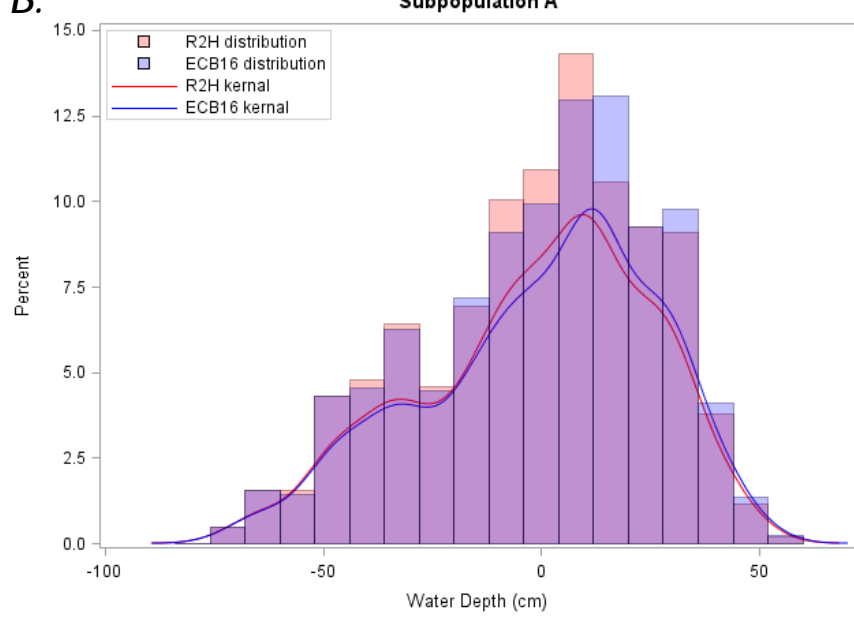

Figure 15. Graphs showing distribution and kernal probability curve of mean subpopulation water depths during, $A$, early (Mar-Apr) and, $B$, late (May-July 15) breeding seasons, and $C$, daily difference in water depth between the R2H scenario and baseline condition (ECB), in subpopulation A. [cm, centimeter; CSSS, Cape Sable seaside sparrow] 
A.

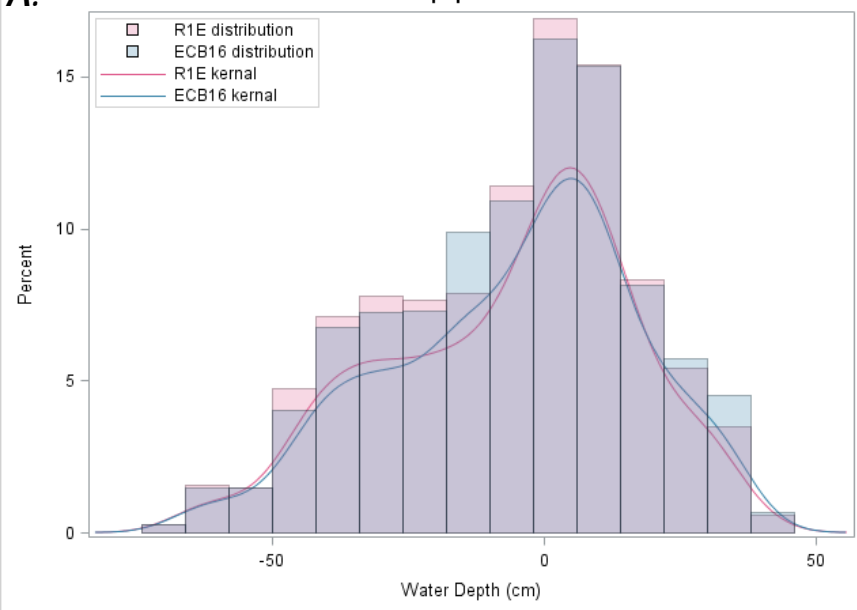

B.

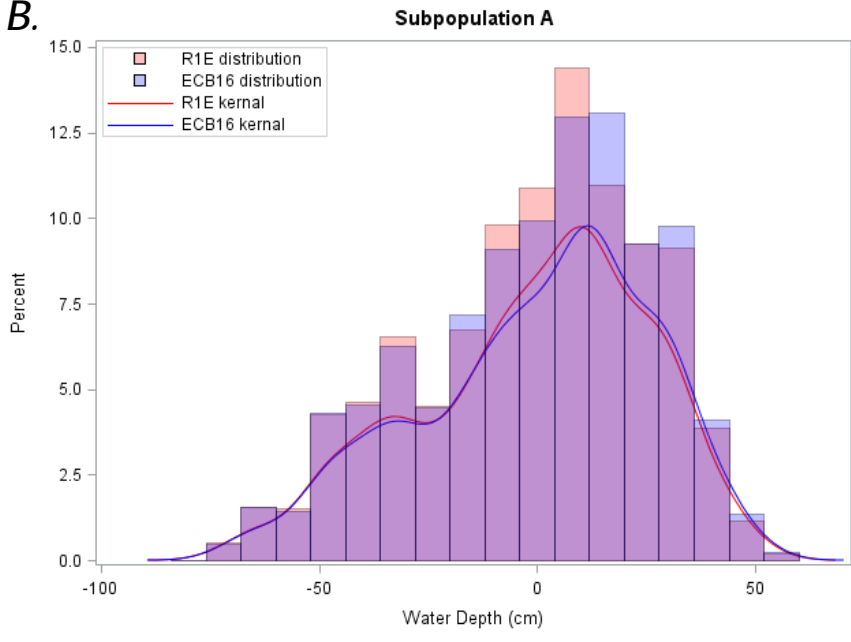

Subpopulation A

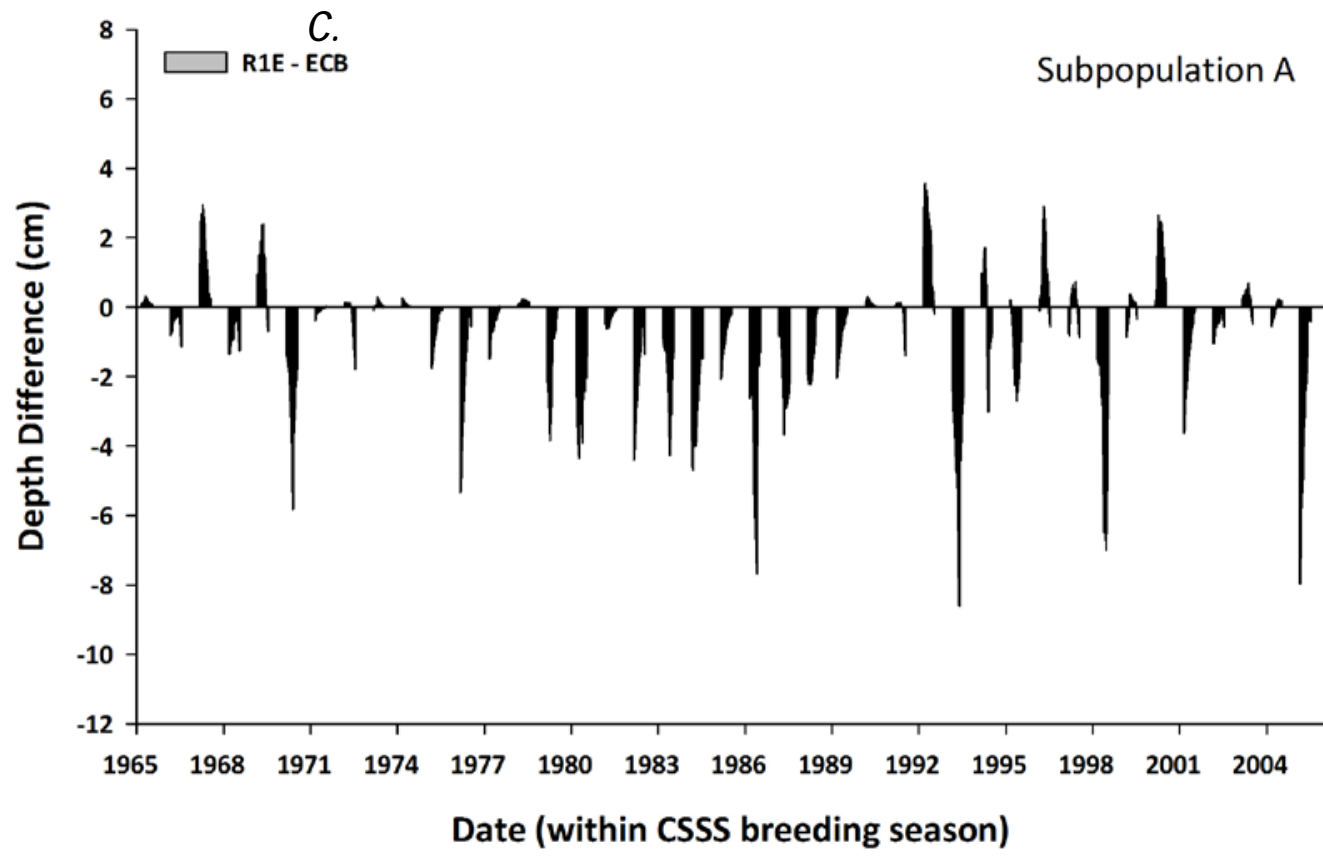

Figure 16. Graphs showing distribution and kernal probability curve of mean subpopulation water depths during, $A$, early (Mar-Apr) and, $B$, late (May-July 15) breeding seasons, and $C$, daily difference in water depth between the R1E scenario and baseline condition (ECB), in subpopulation A. [cm, centimeter; CSSS, Cape Sable seaside sparrow] 


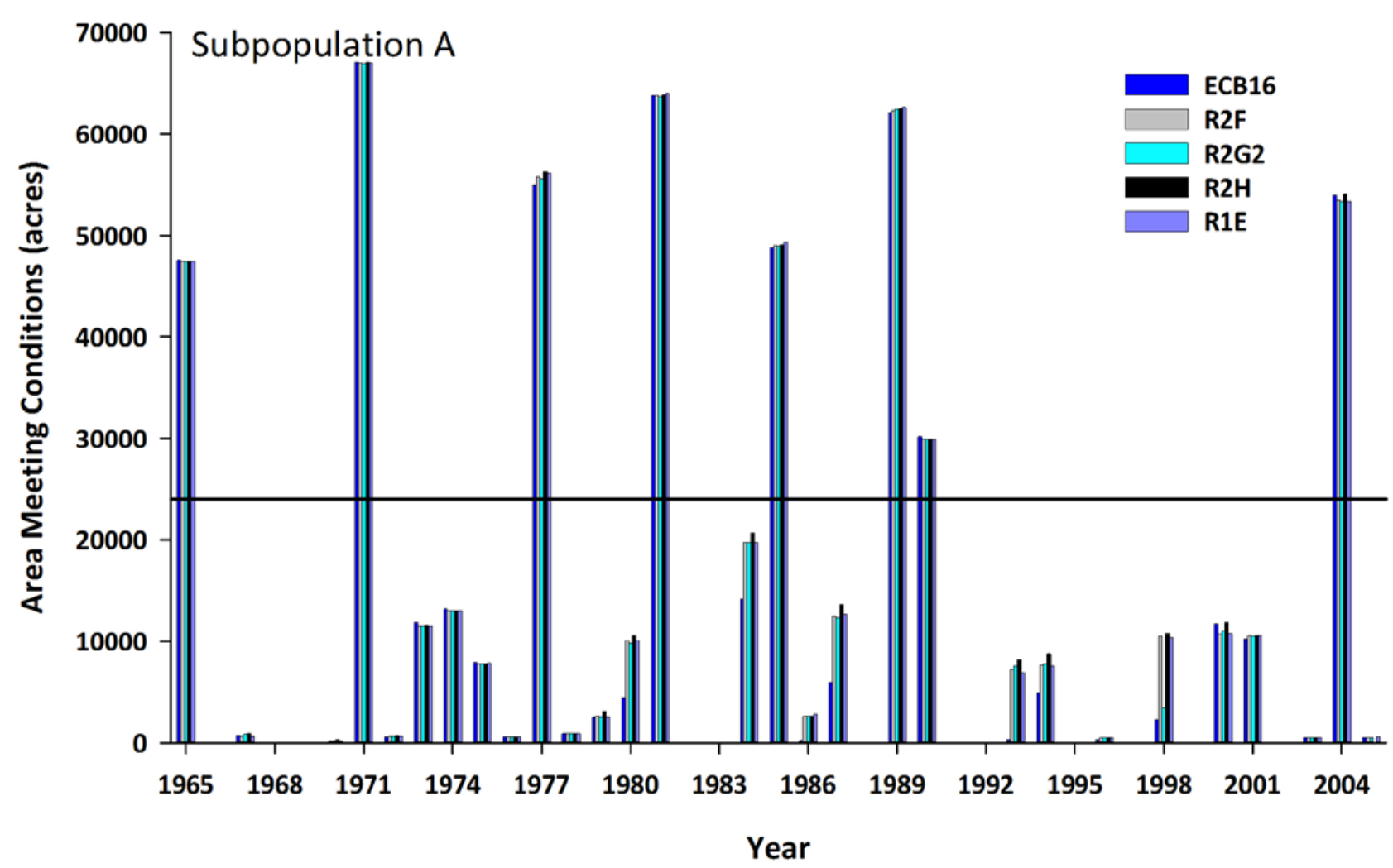

Figure 17. Graphs showing area within subpopulations A, A1, and A2 (1965-2005) meeting FWS target of more than 90 consecutive dry days within the breeding season (Mar 1-Jul 15) for four scenarios (R2F, R2G2, R2H, R1E) and the baseline condition (ECB). 

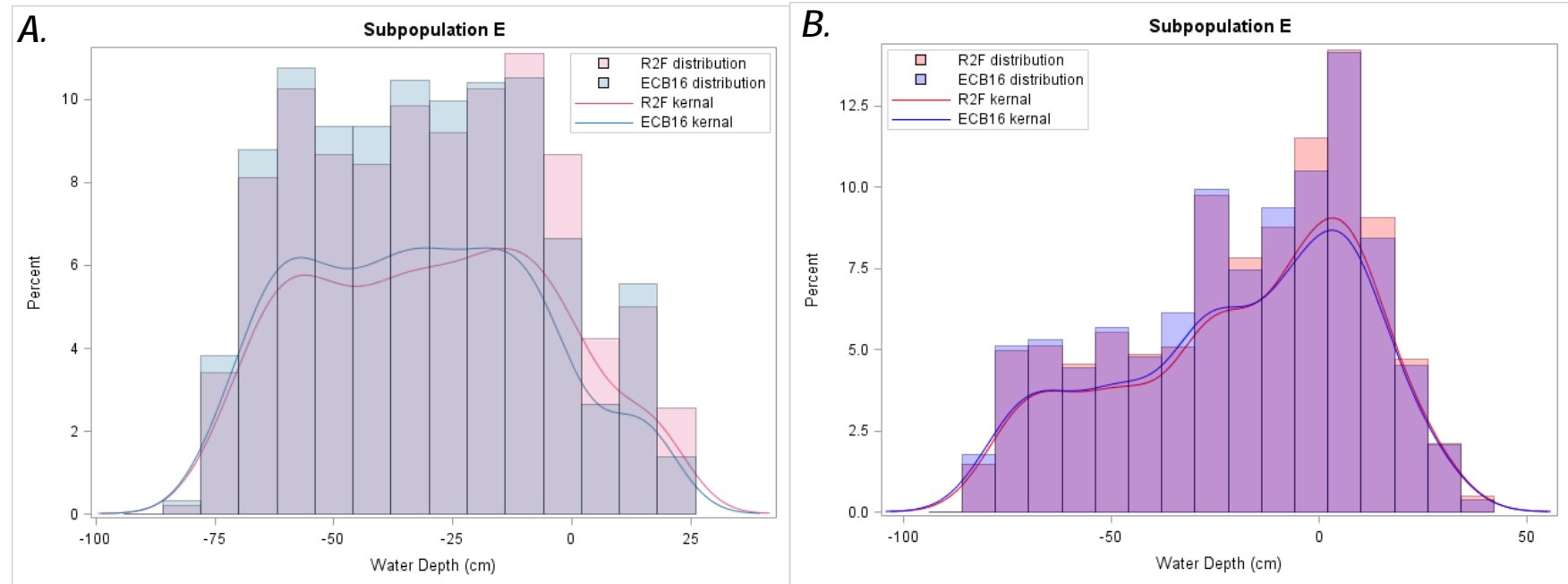

C.

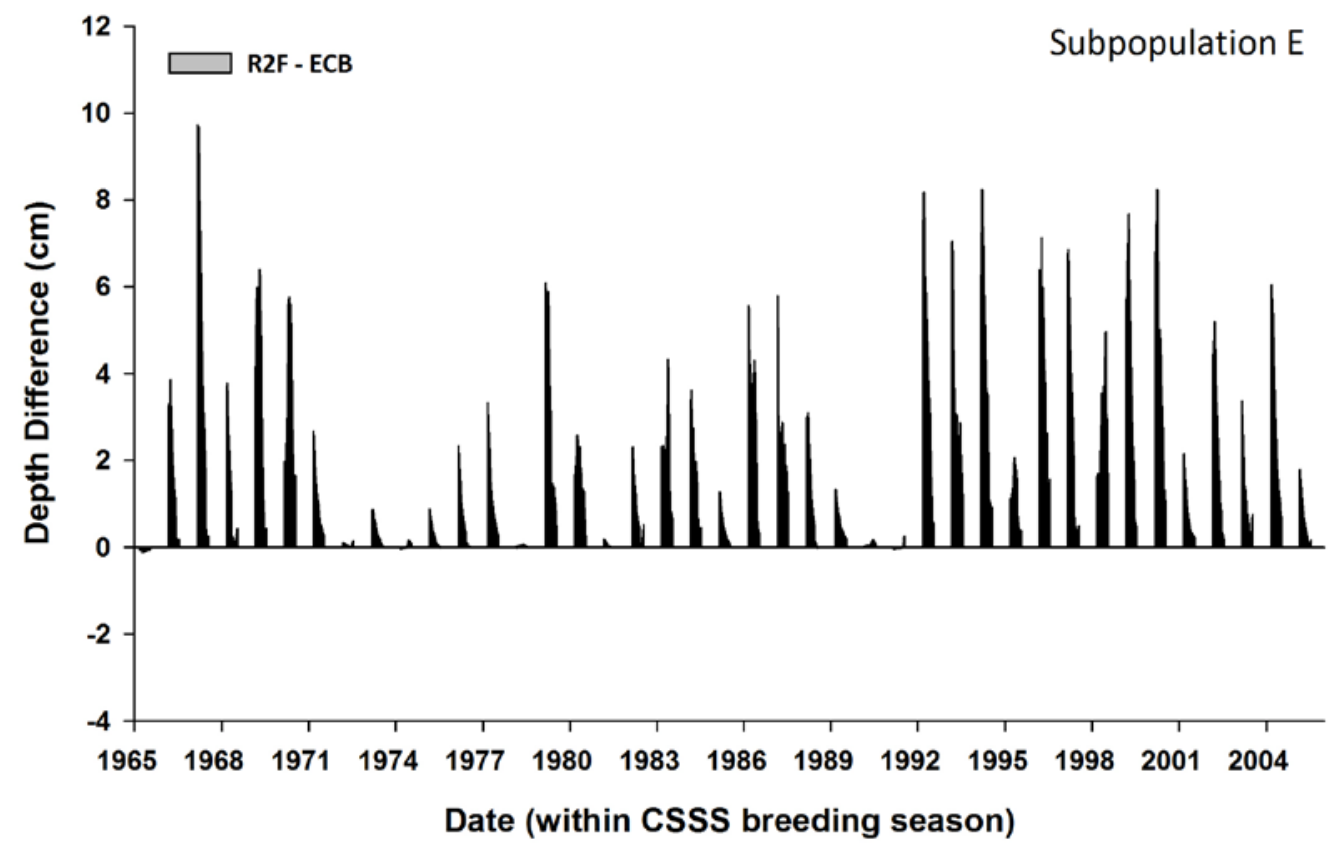

Figure 18. Graphs showing distribution and kernal probability curve of mean subpopulation water depths during, $A$, early (Mar-Apr) and, $B$, late (May-July 15 ) breeding seasons, and $C$, daily difference in water depth between the R2F scenario and baseline condition (ECB), in subpopulation E. [cm, centimeter; CSSS, Cape Sable seaside sparrow] 

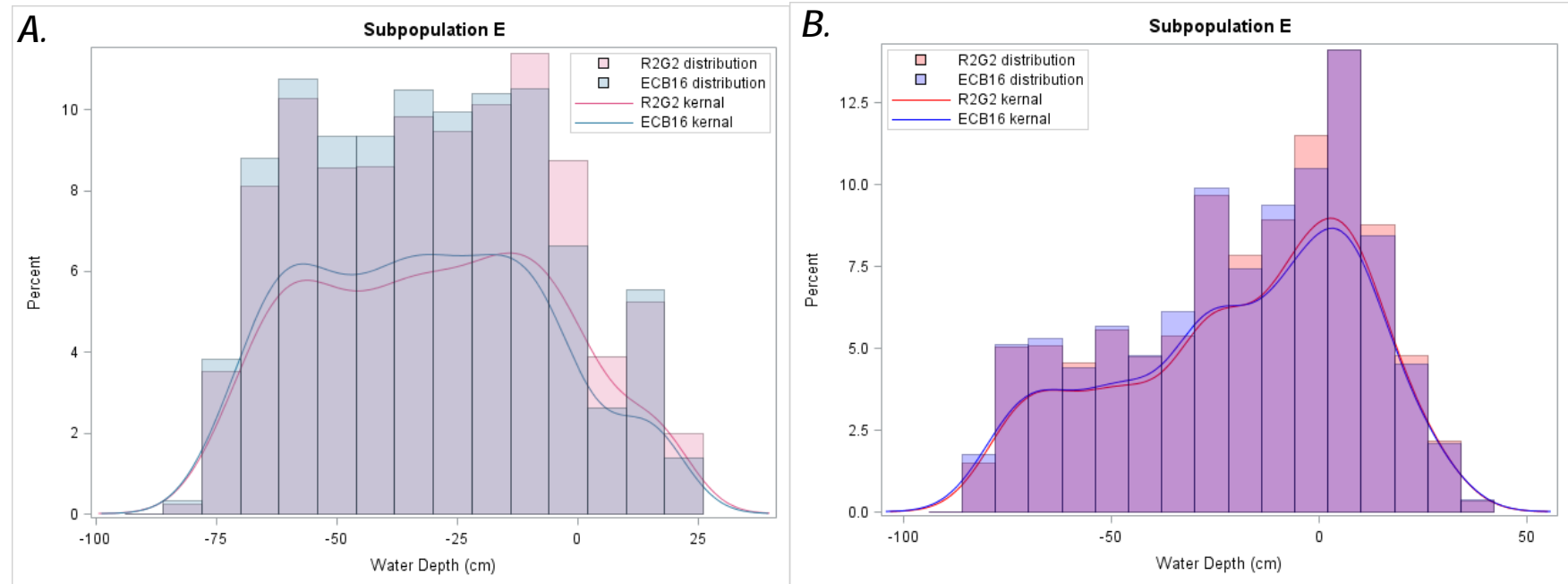

C.

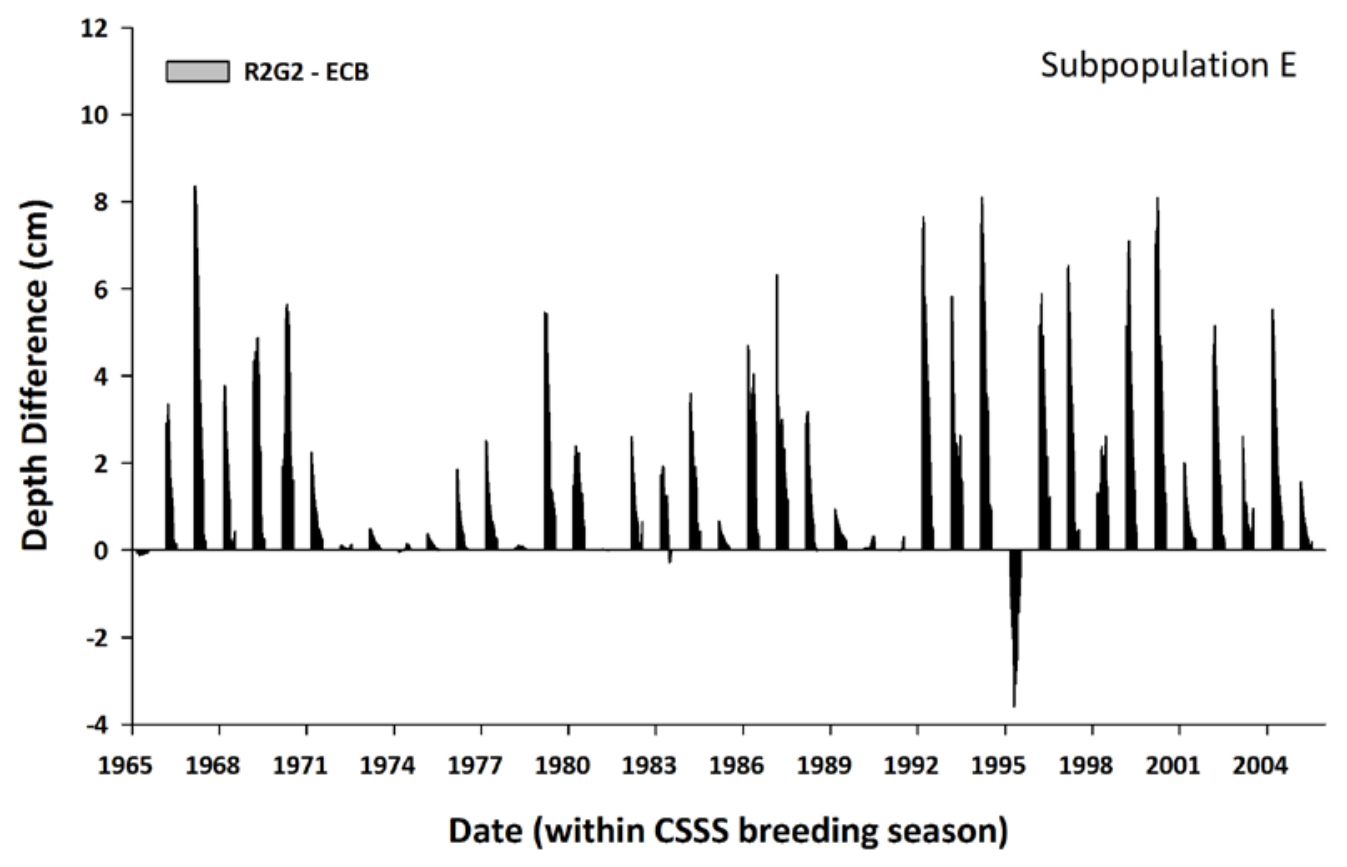

Figure 19. Graphs showing distribution and kernal probability curve of mean subpopulation water depths during, $A$, early (Mar-Apr) and, $B$, late (May-July 15) breeding seasons, and $C$, daily difference in water depth between the R2G2 scenario and baseline condition (ECB), in subpopulation E. [cm, centimeter; CSSS, Cape Sable seaside sparrow] 
A.

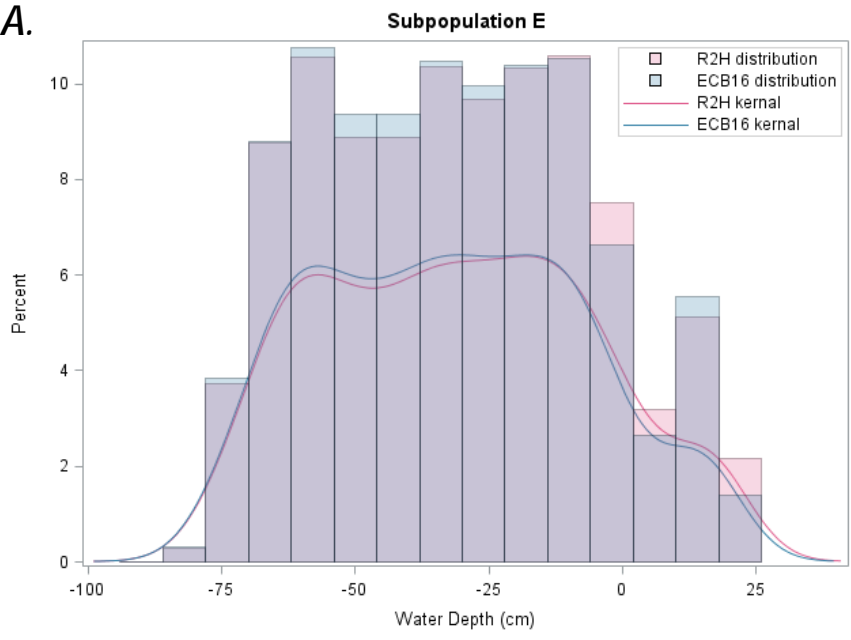

c.

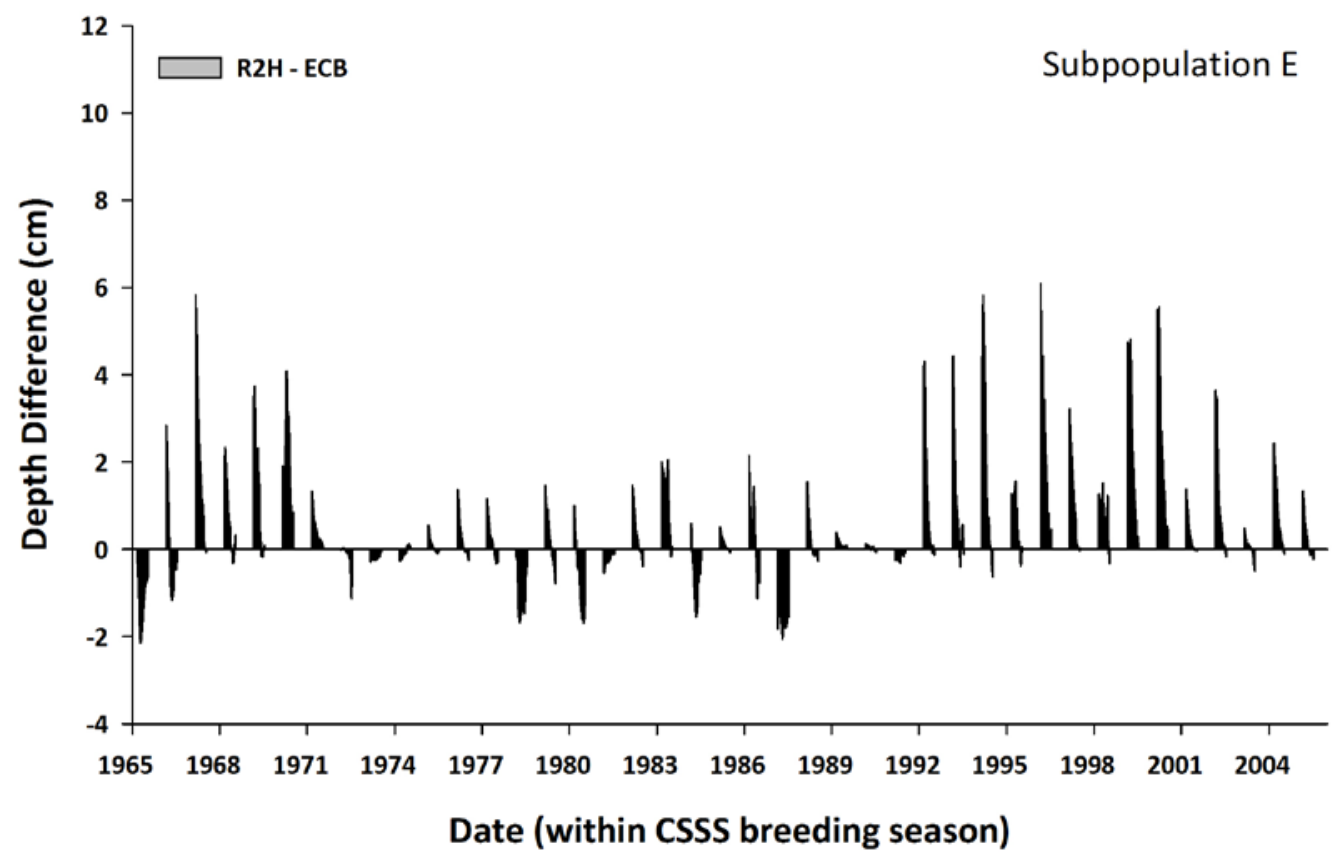

B.

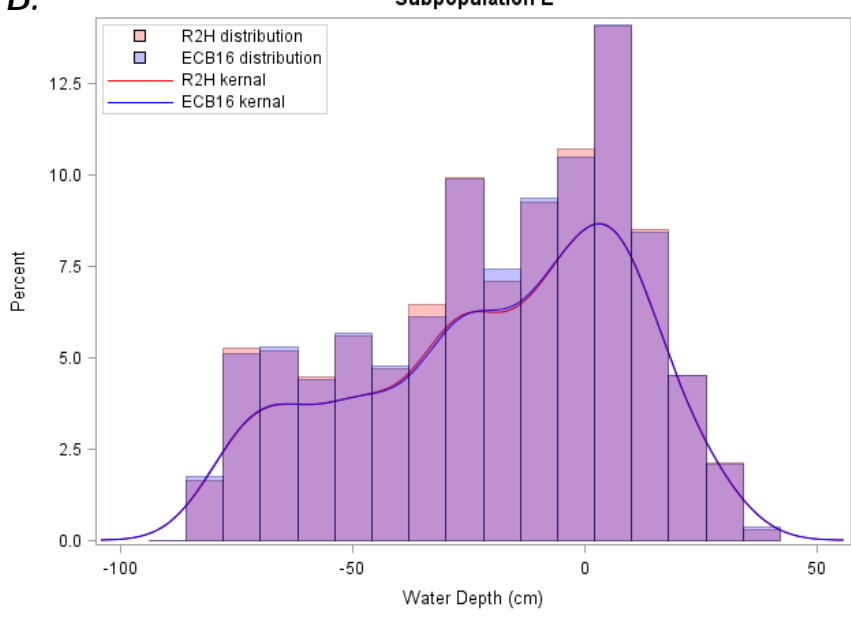



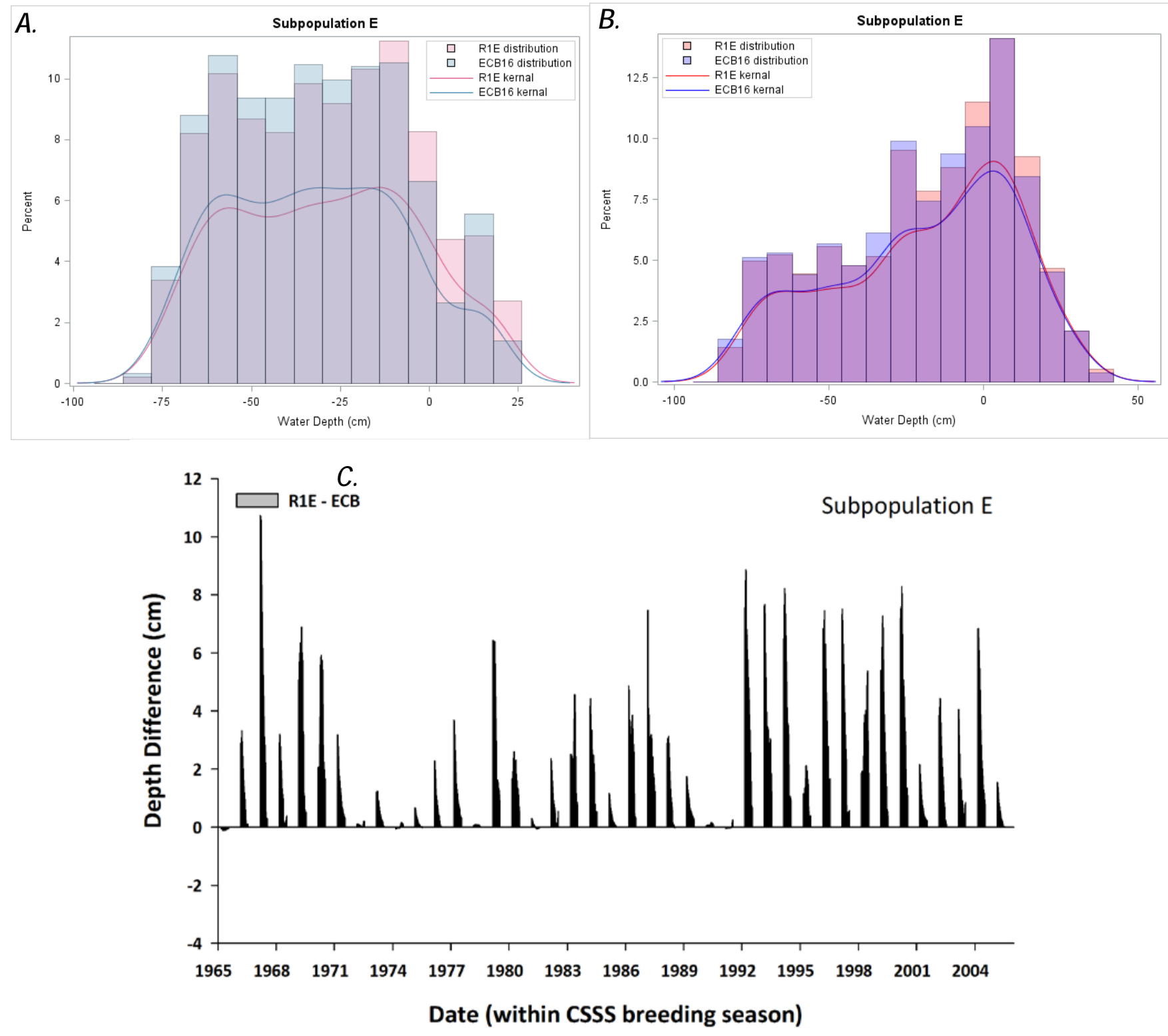

Figure 21. Graphs showing distribution and kernal probability curve of mean subpopulation water depths during, $A$, early (Mar-Apr) and, $B$, late (May-July 15) breeding seasons, and $C$, daily difference in water depth between the R1E scenario and baseline condition (ECB), in subpopulation E. [cm, centimeter; CSSS, Cape Sable seaside sparrow] 


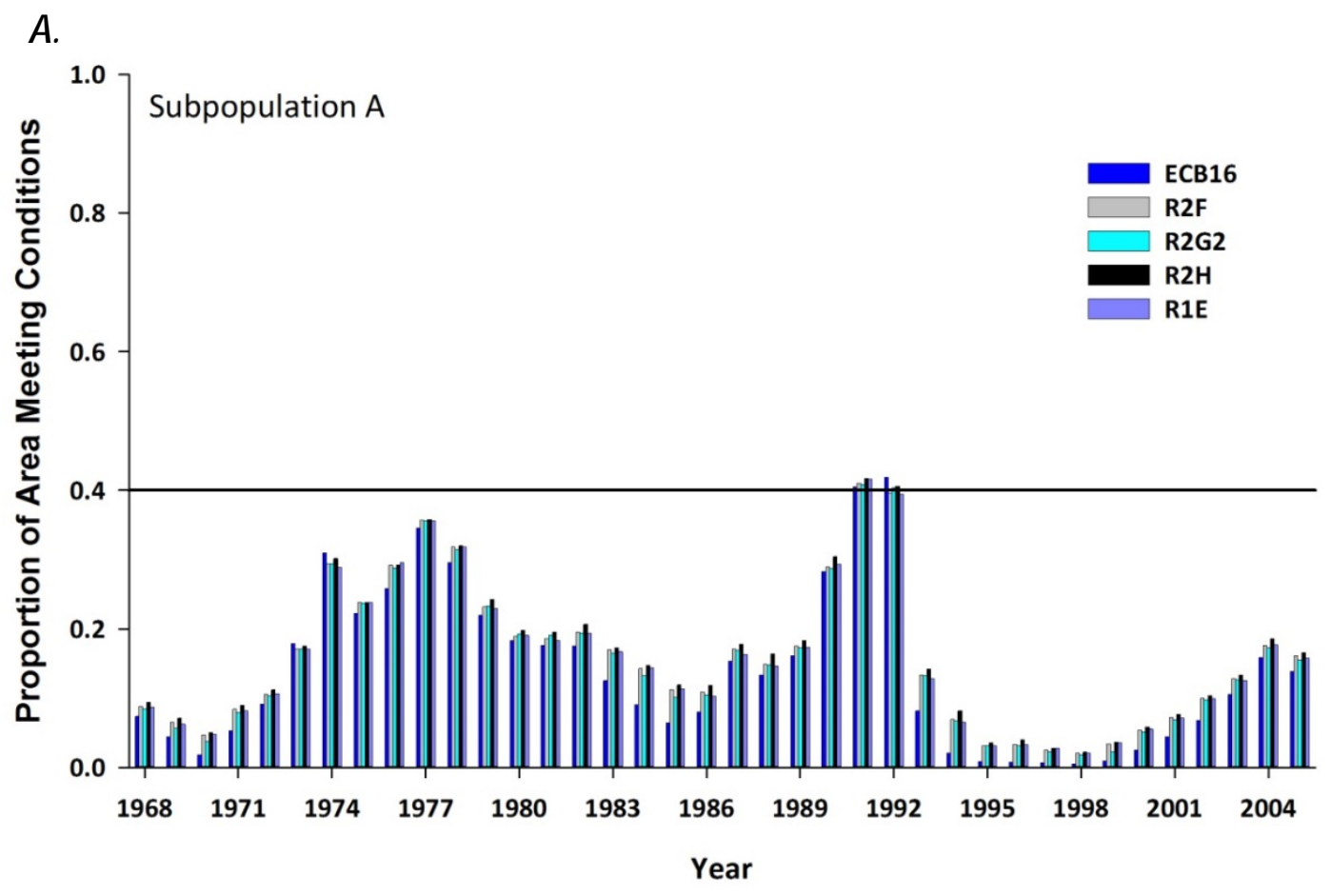

B.

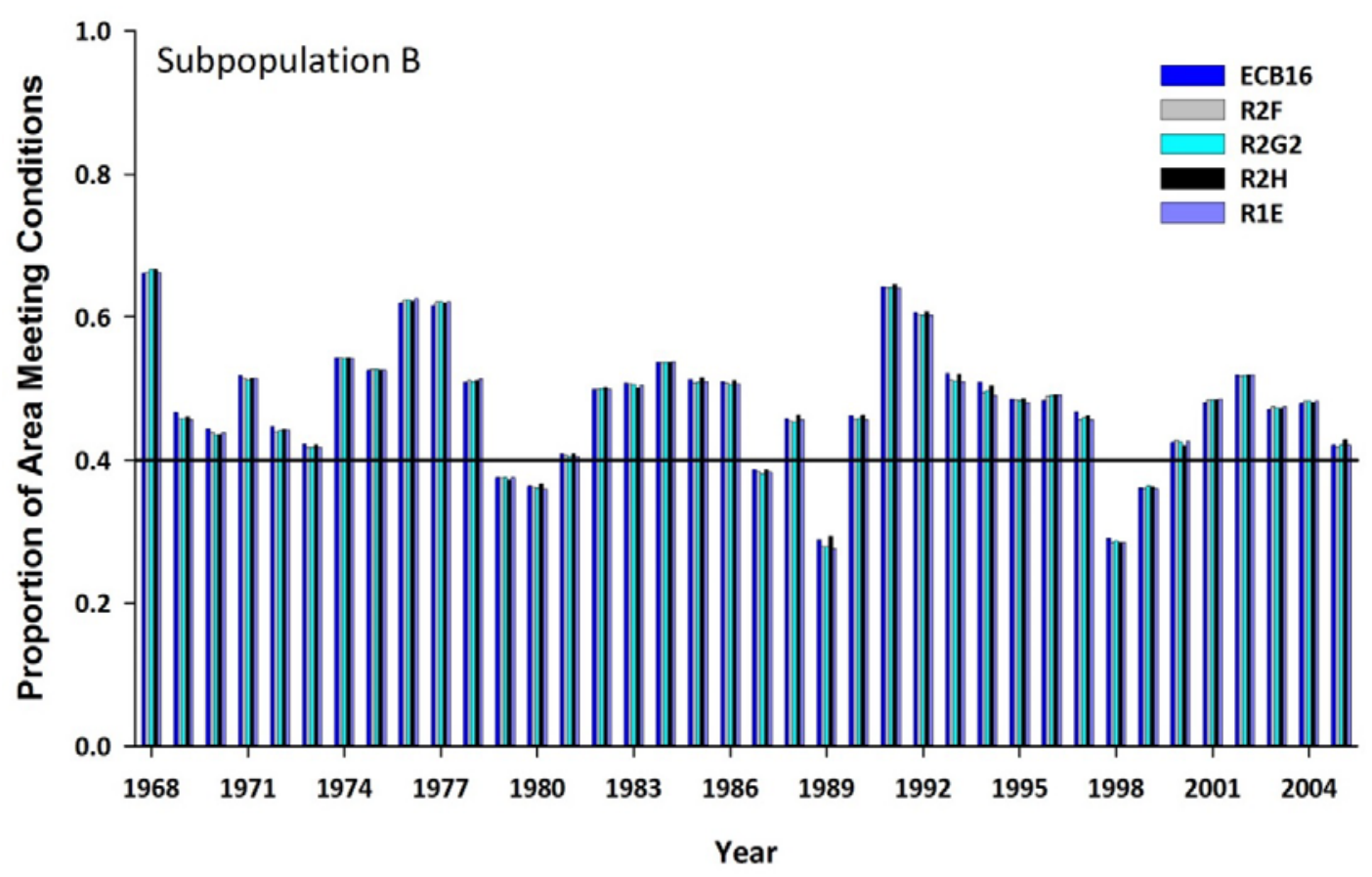




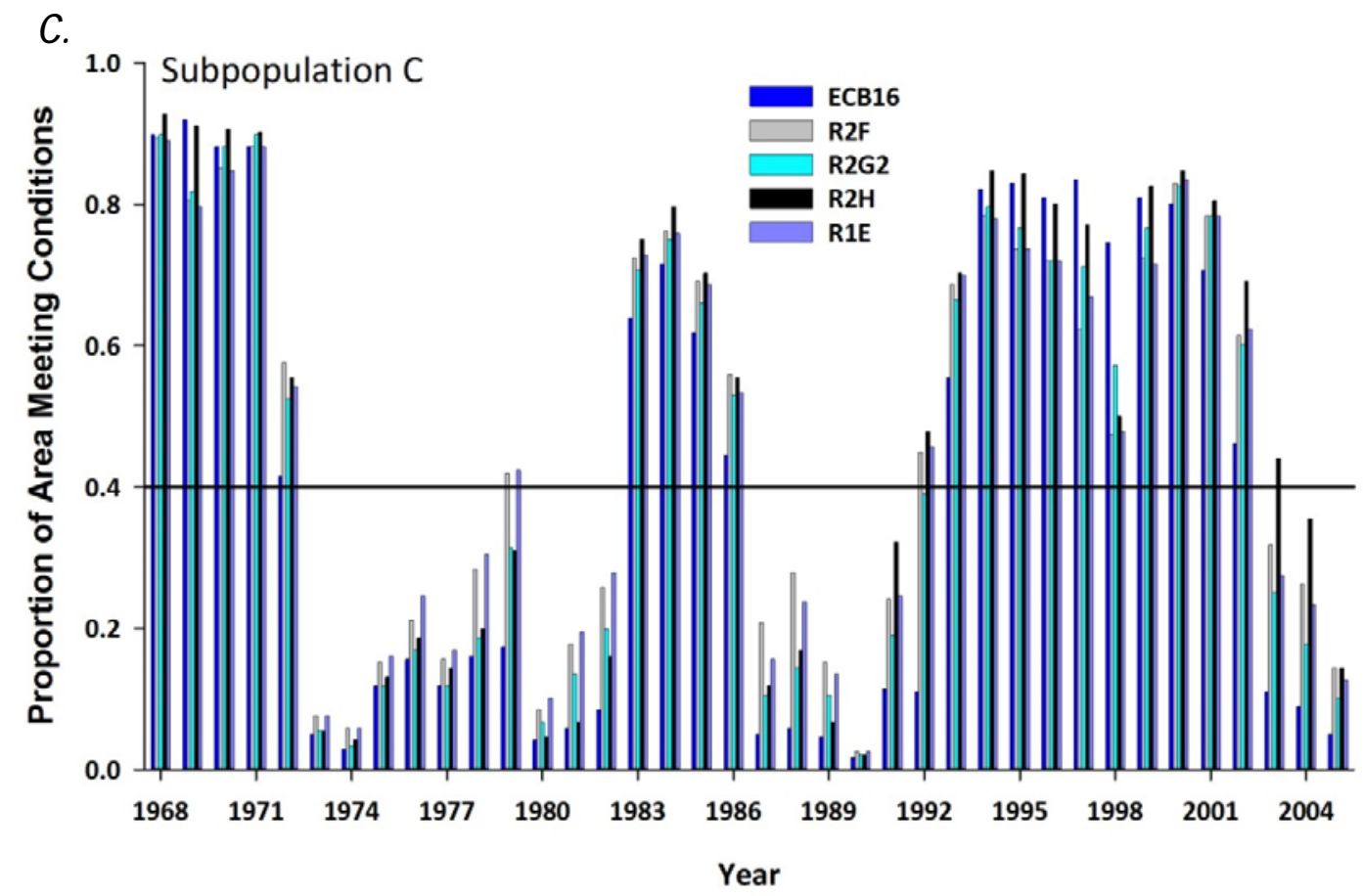

D.

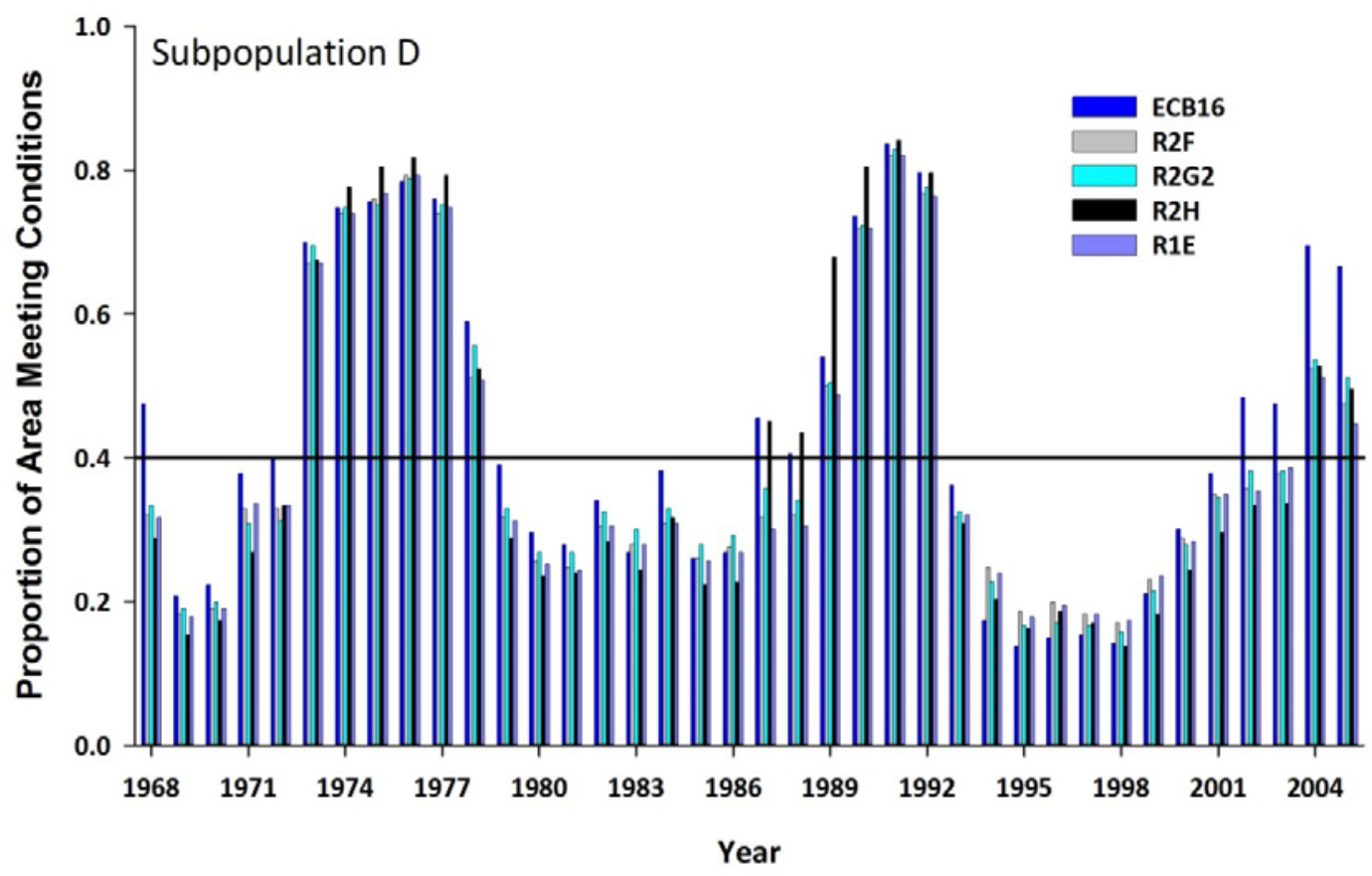



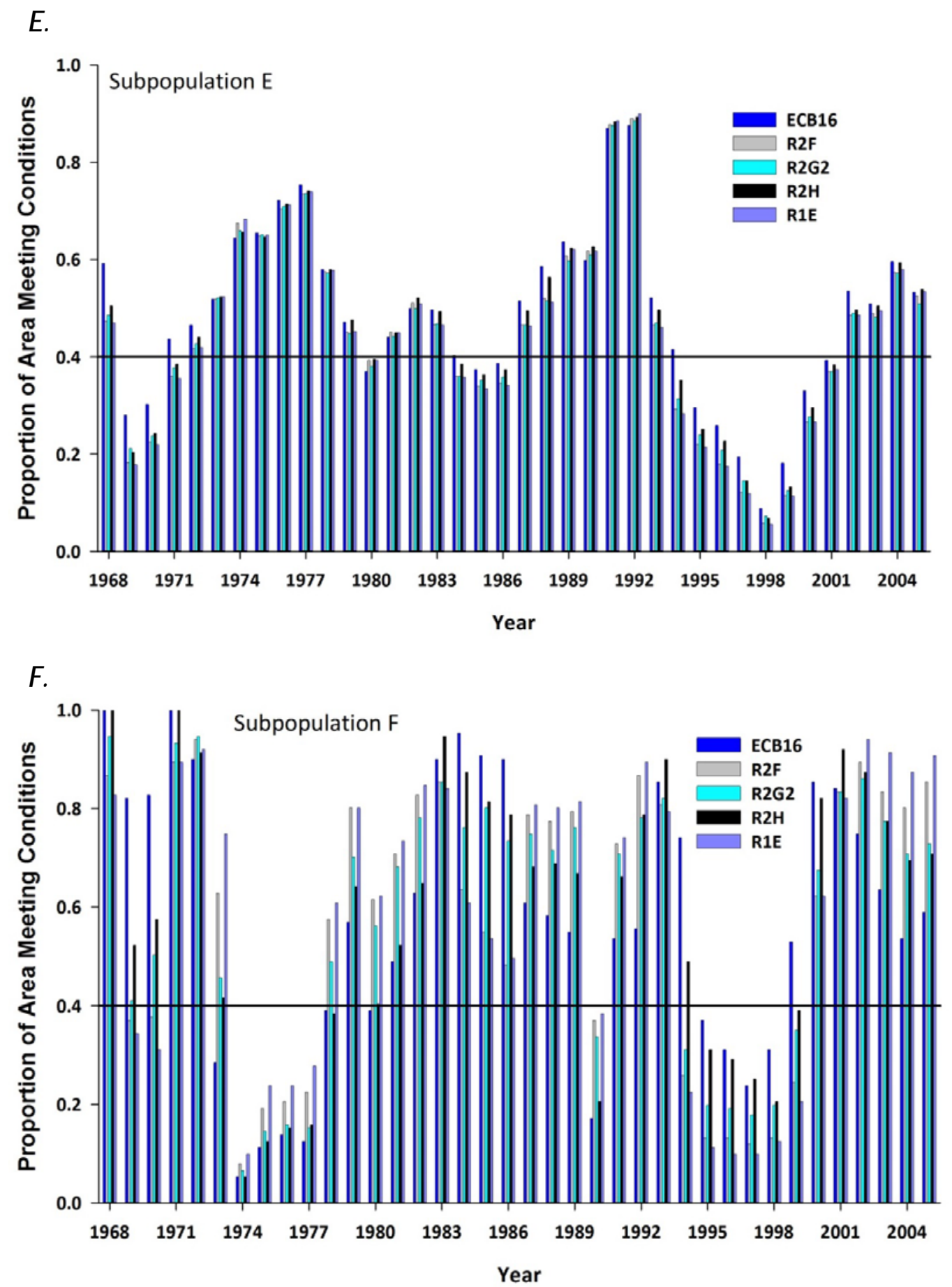

Figure 22. Graphs showing proportion of total area of subpopulation $A(A),. B(B),. C(C),. D(D),. E(E$.$) , and F$ $(F$.) meeting U.S. Fish and Wildlife Service target 4-year hydroperiod of 90-210 days for 4 scenarios (R2F, R2G2, R2H, R1E) and the baseline condition (ECB; 1968-2005). 

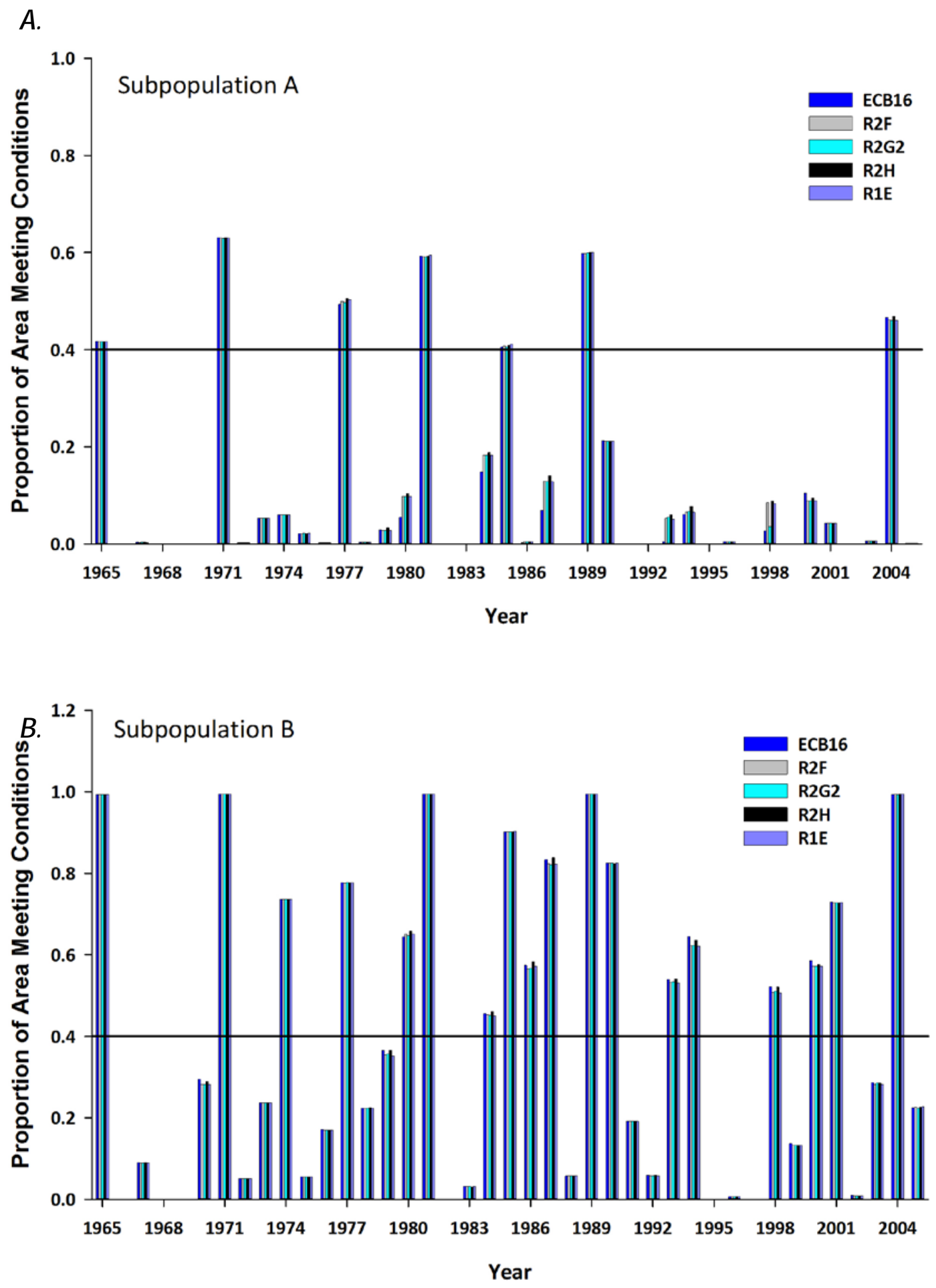


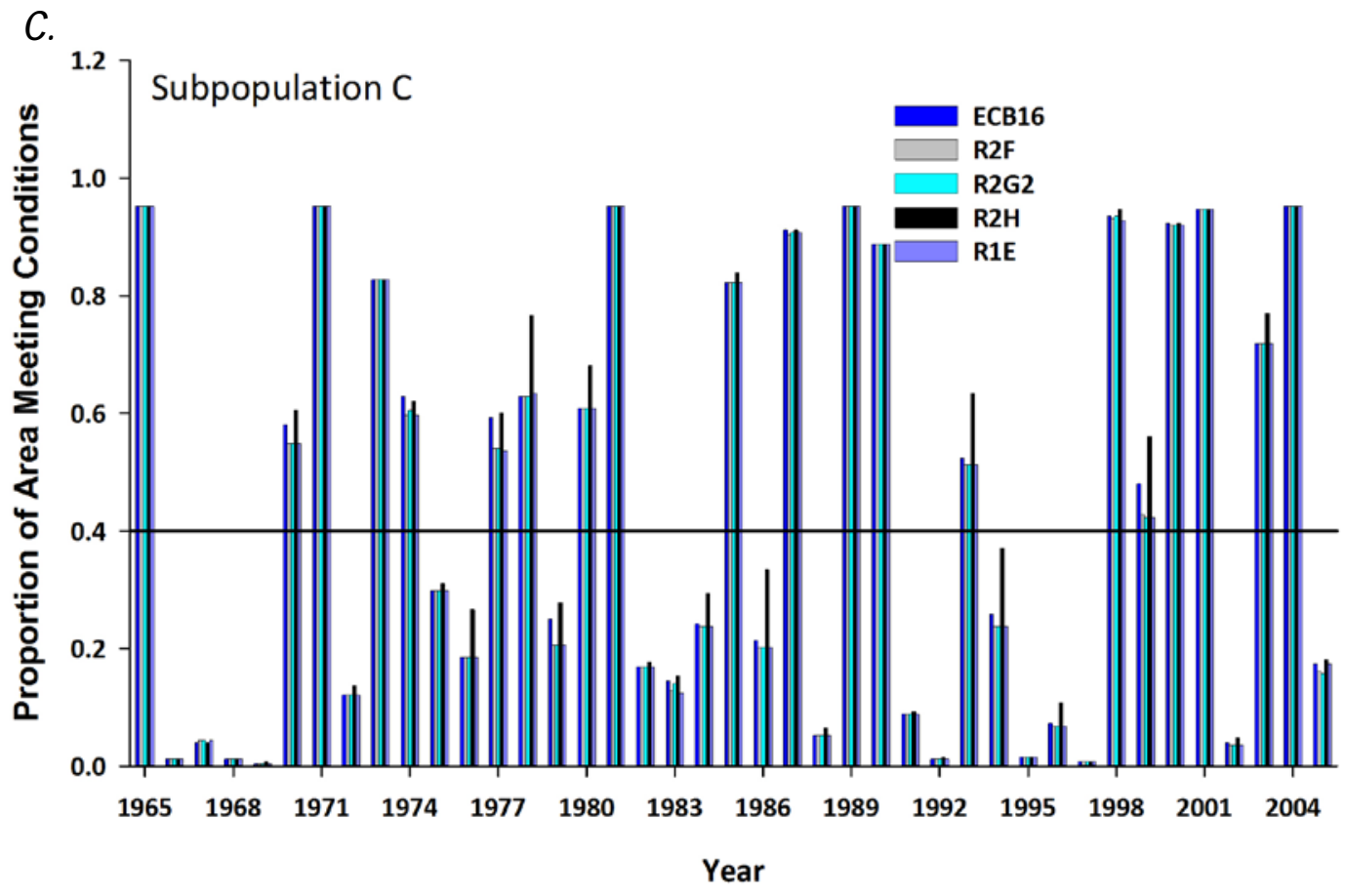

D.

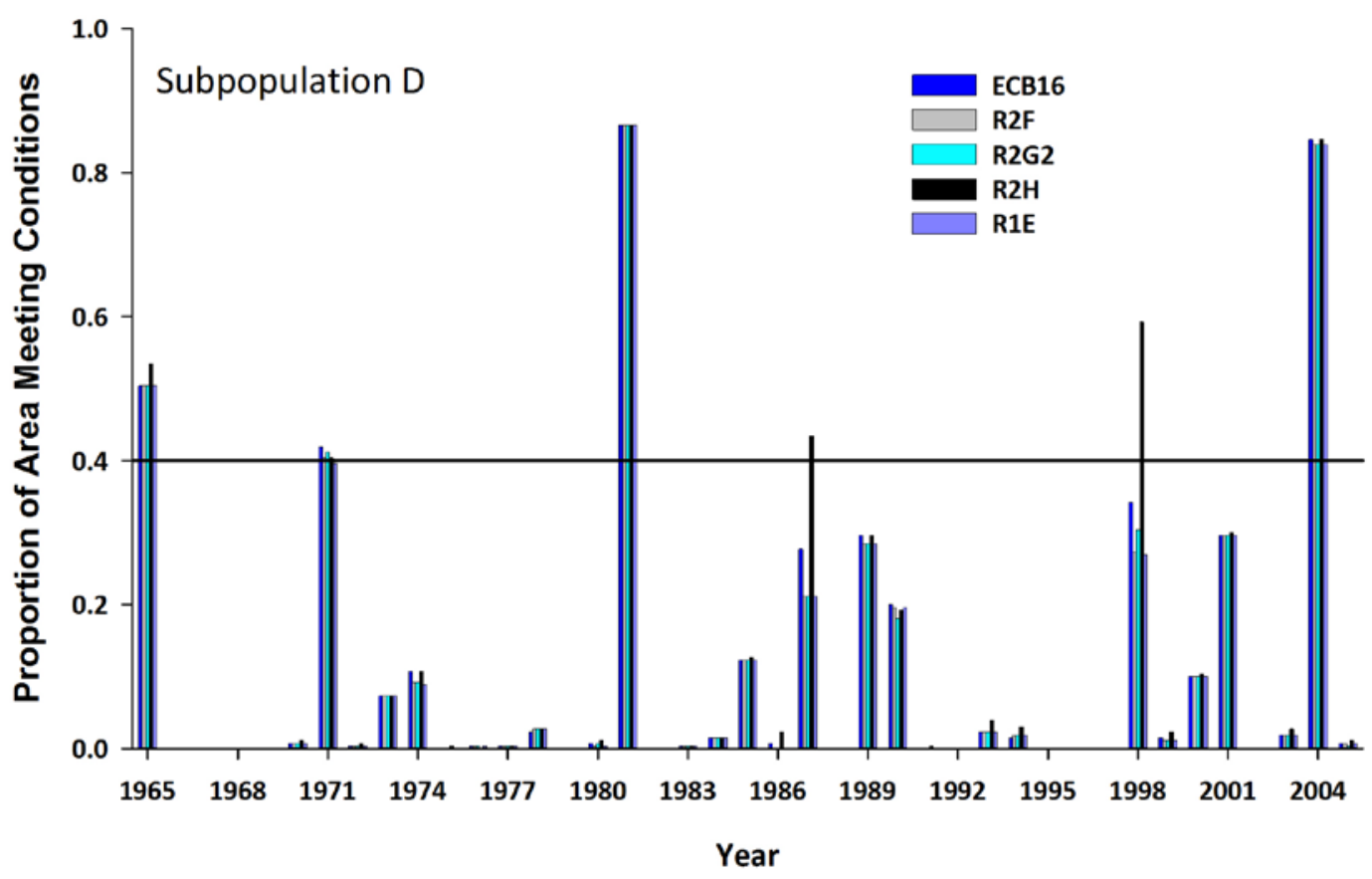


E.

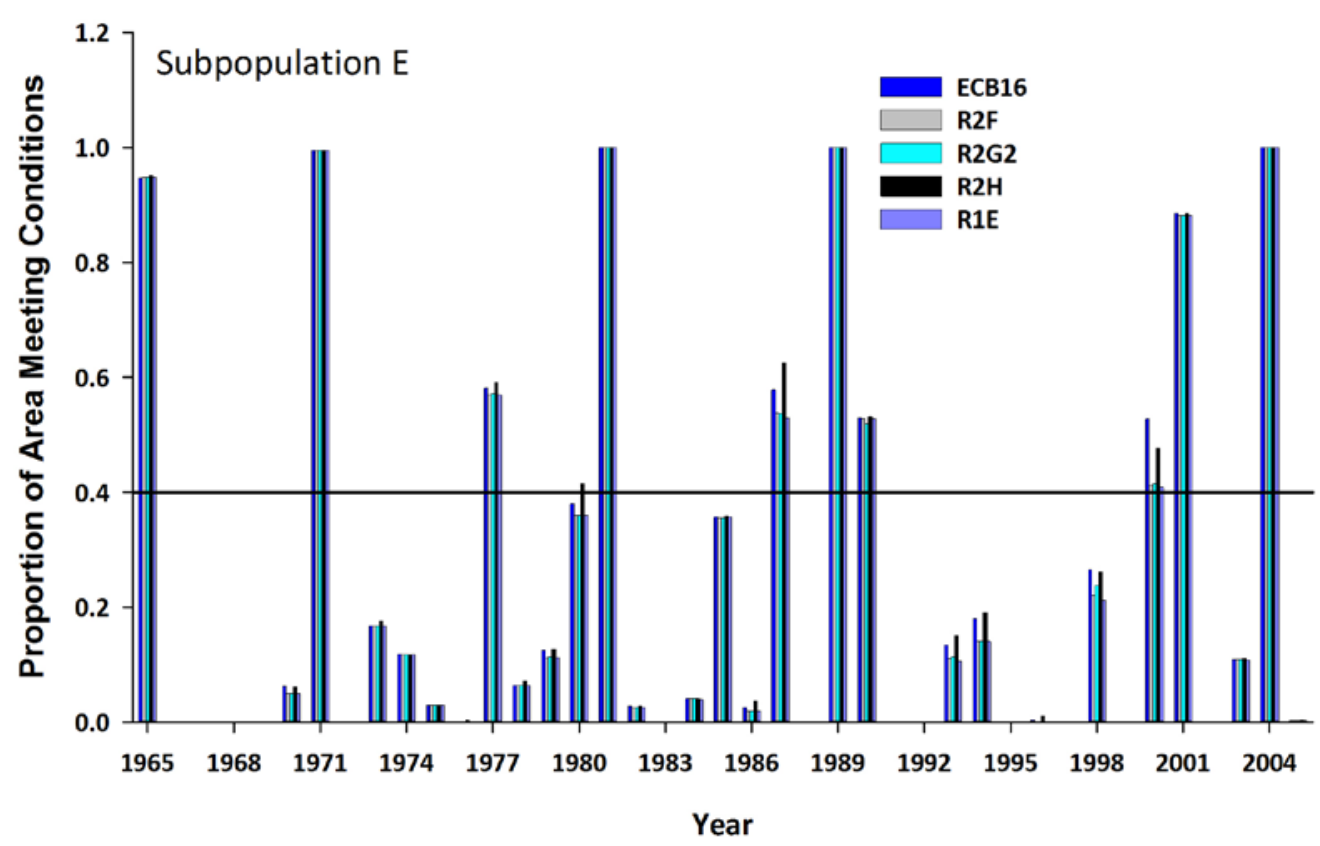

F.

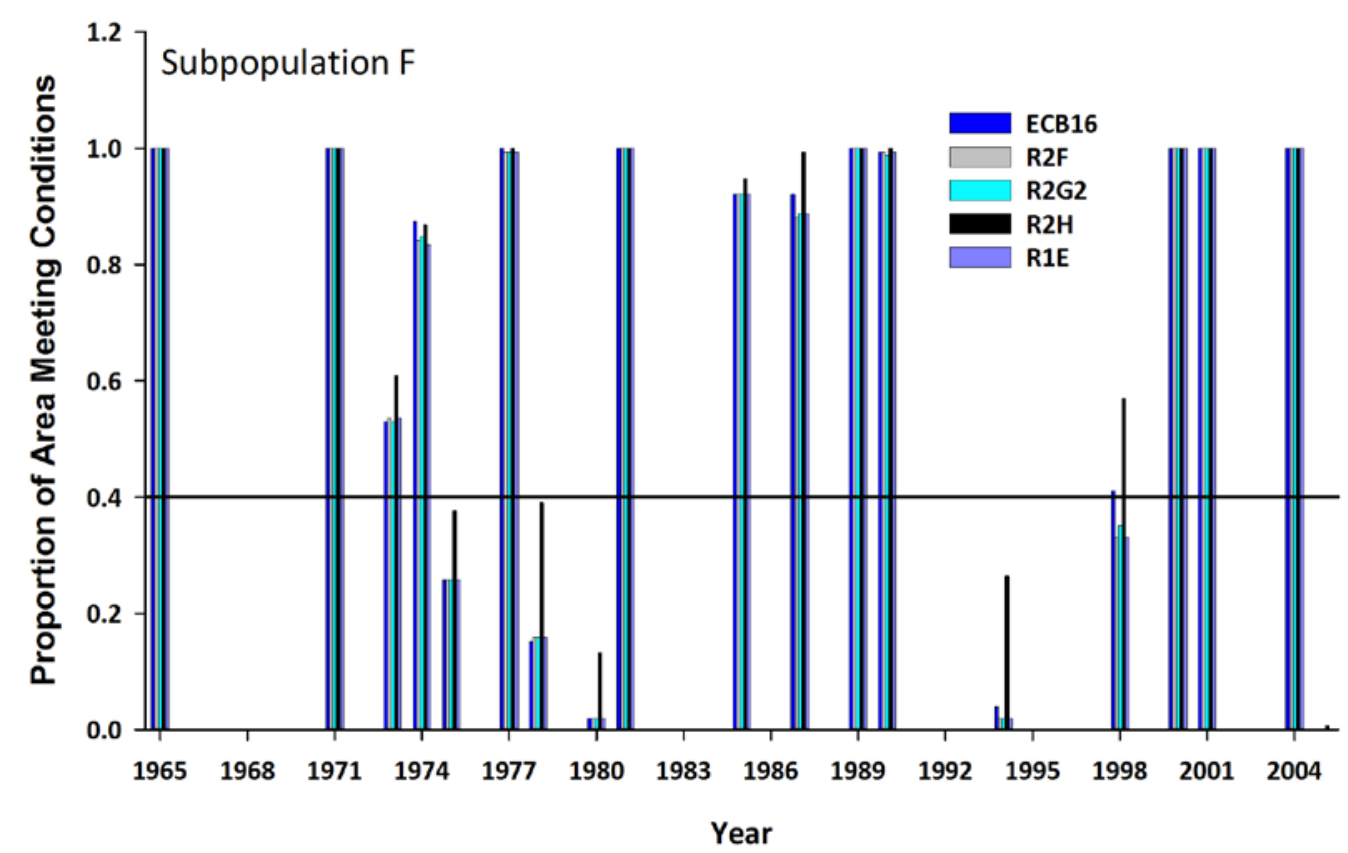

Figure 23. Graphs showing proportion of total area of subpopulation $A(A),. B(B),. C(C),. D(D),. E(E$.$) , and F$ (F.) meeting U.S. Fish and Wildlife Service target of $>90$ consecutive dry days within the breeding season (Mar 1Jul 15; 1965 -2005) for 4 scenarios (R2F, R2G2, R2H, R1E) and the baseline condition (ECB). 

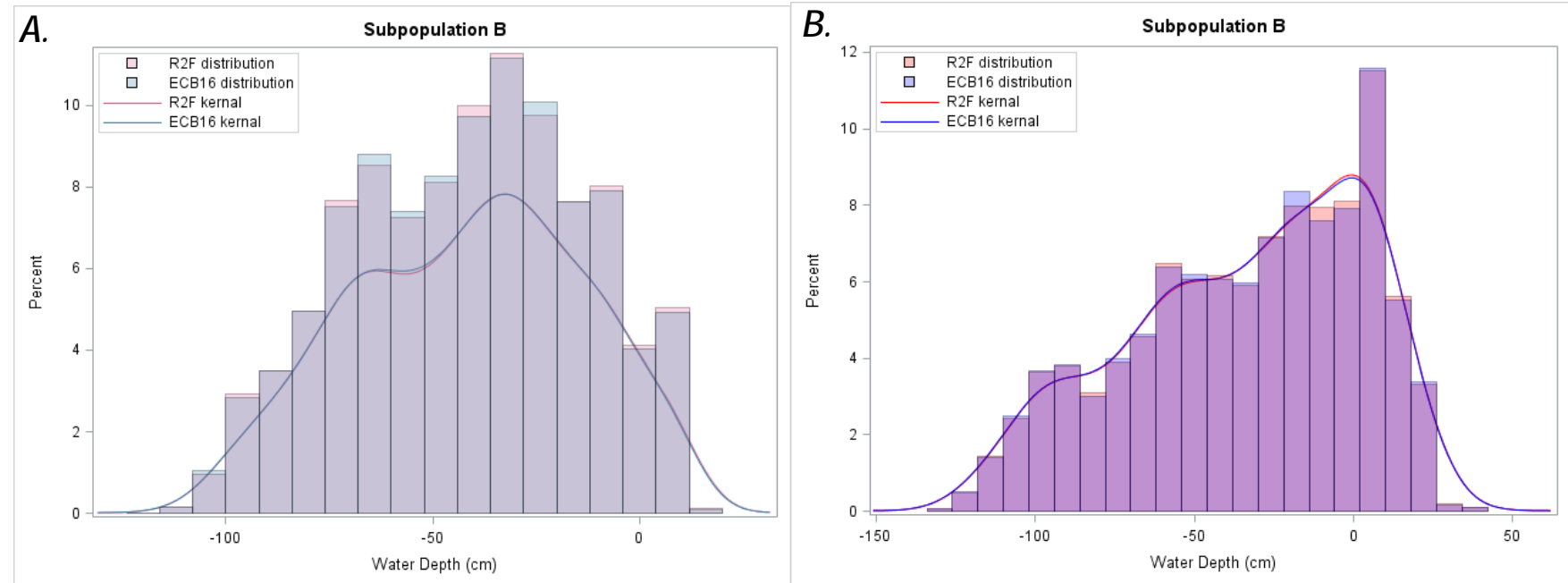

c.

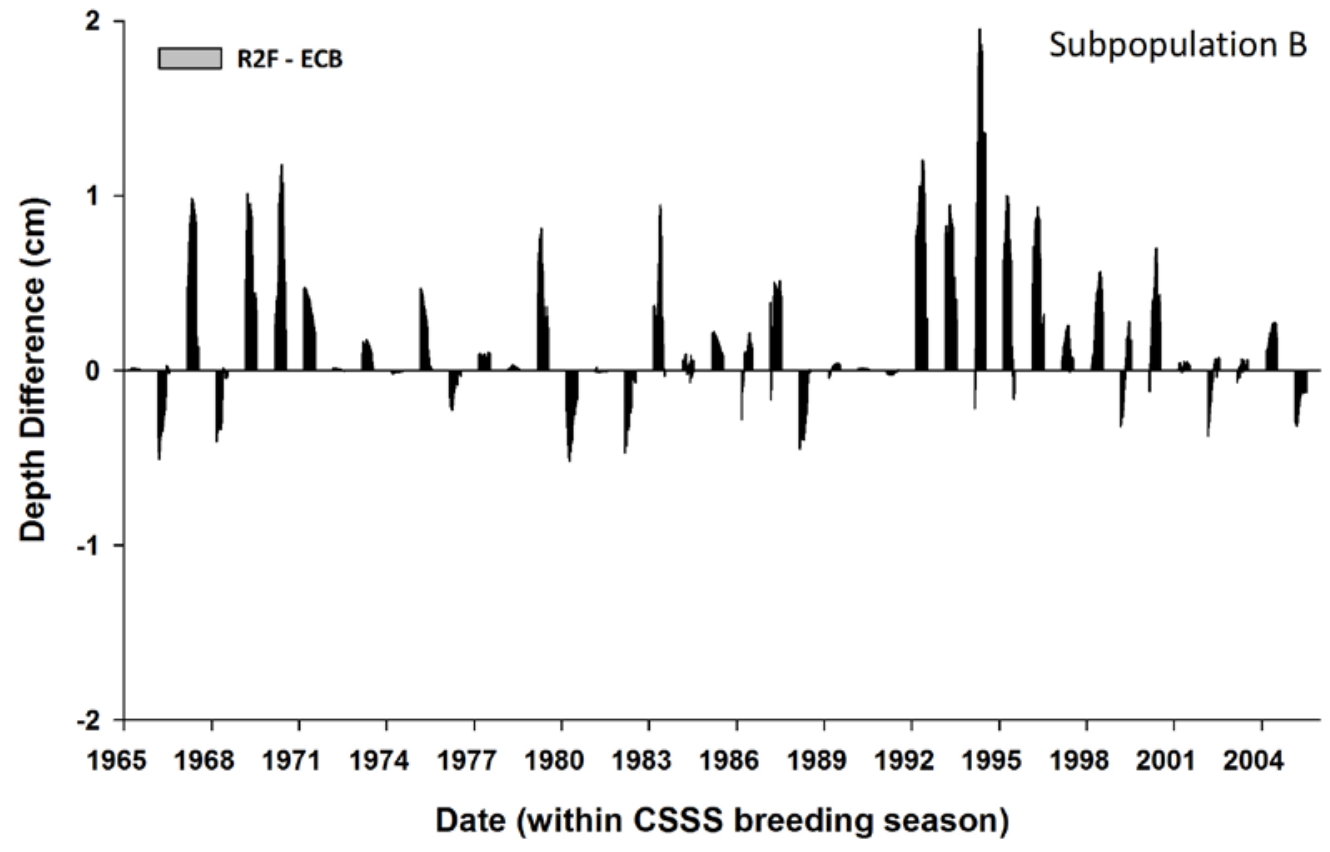

Figure 24. Graphs showing distribution and kernal probability curve of mean subpopulation water depths during, $A$, early (Mar-Apr) and, $B$, late (May-July 15) breeding seasons, and $C$, daily difference in water depth between the R2F scenario and baseline condition (ECB), in subpopulation B. [cm, centimeter; CSSS, Cape Sable seaside sparrow] 
A.

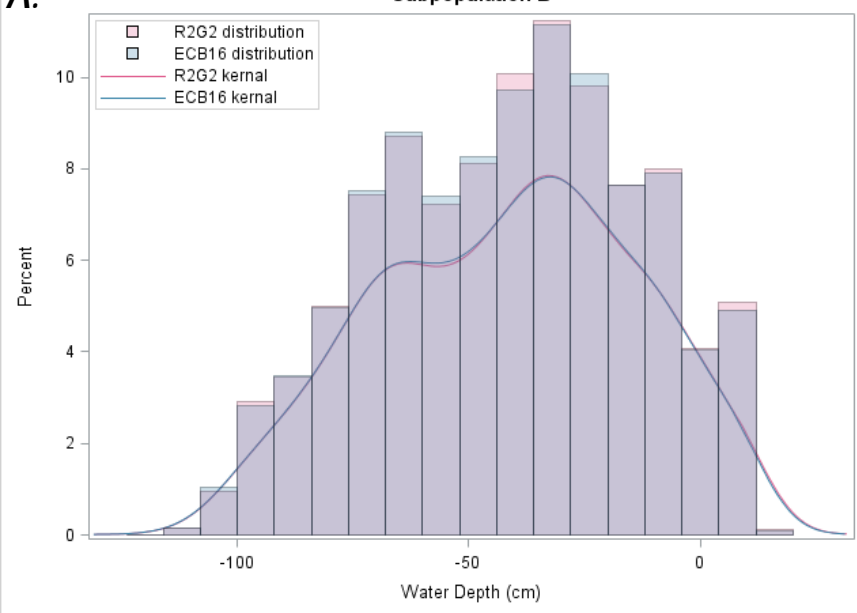

B.

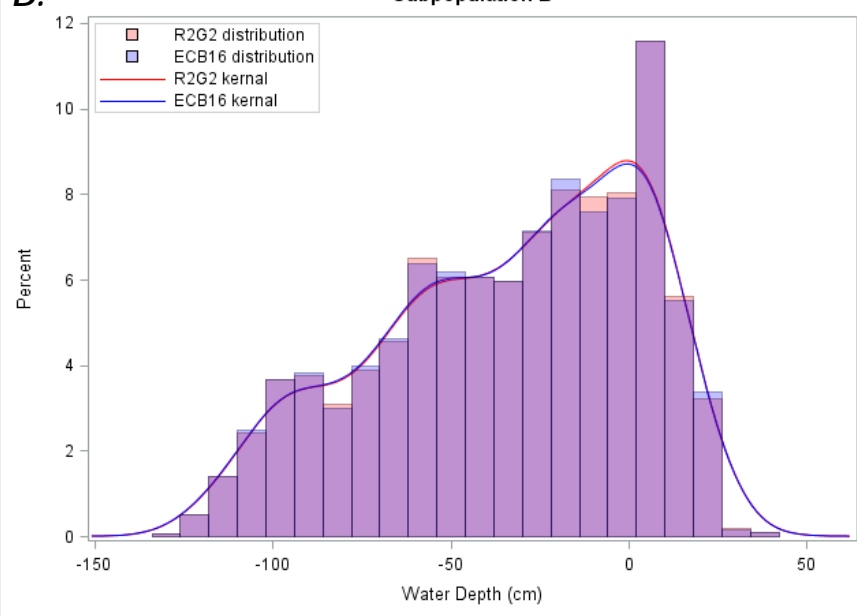

C.

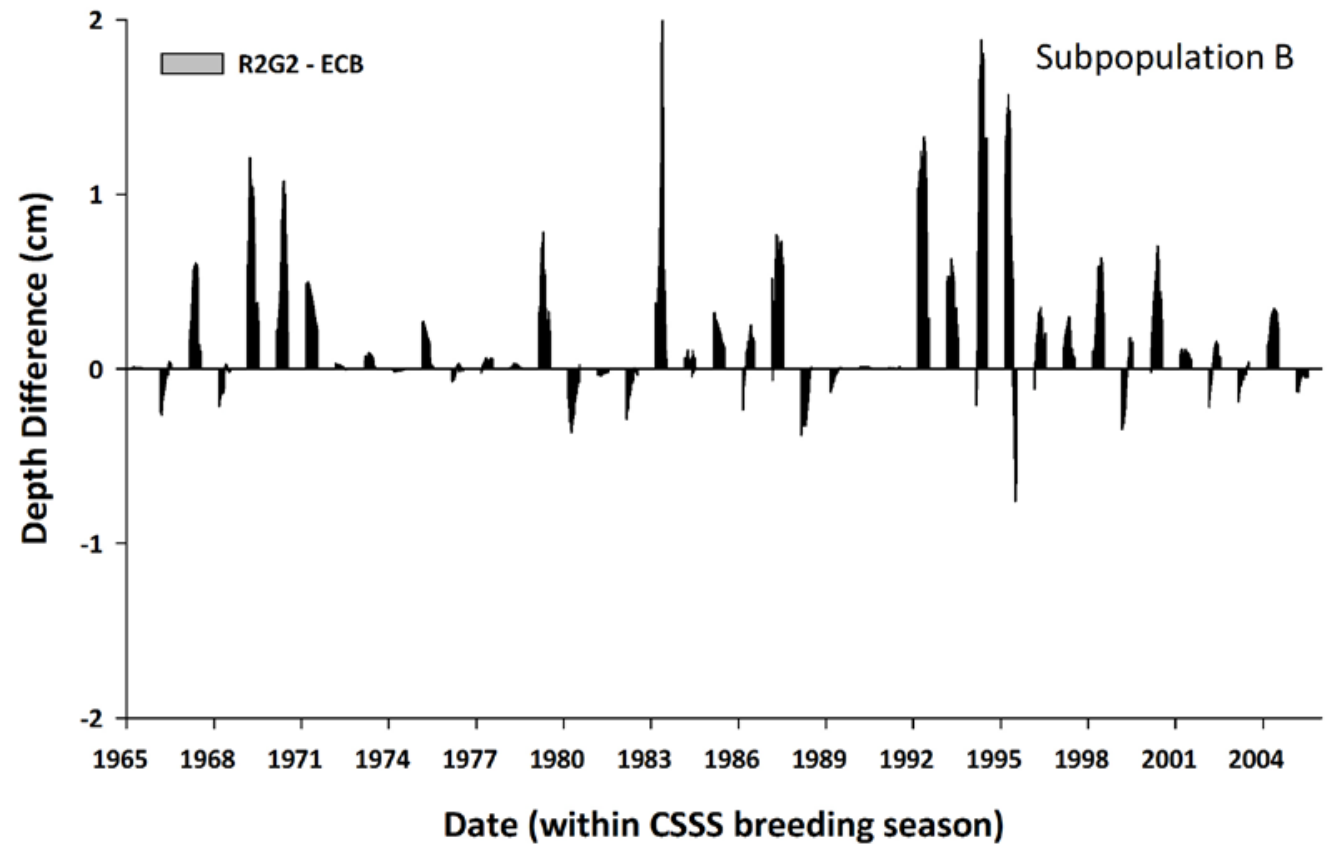

Figure 25. Graphs showing distribution and kernal probability curve of mean subpopulation water depths during, $A$, early (Mar-Apr) and, $B$, late (May-July 15) breeding seasons, and $C$, daily difference in water depth between the R2G2 scenario and baseline condition (ECB), in subpopulation B. [cm, centimeter; CSSS, Cape Sable seaside sparrow] 
A.

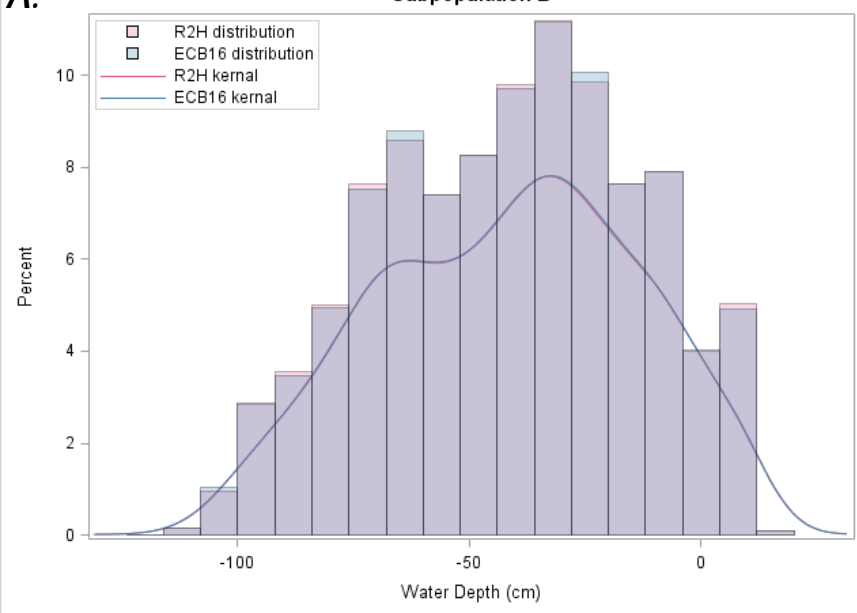

B.

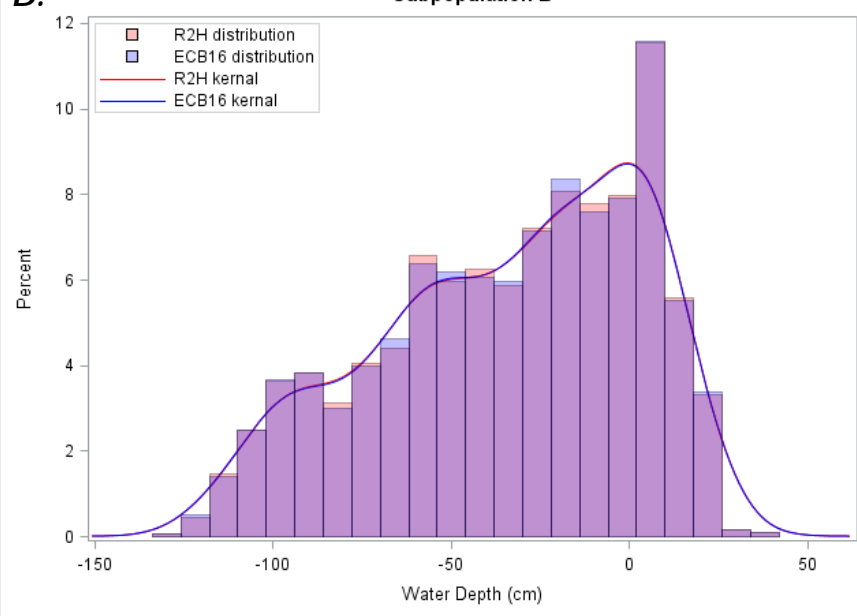

C.

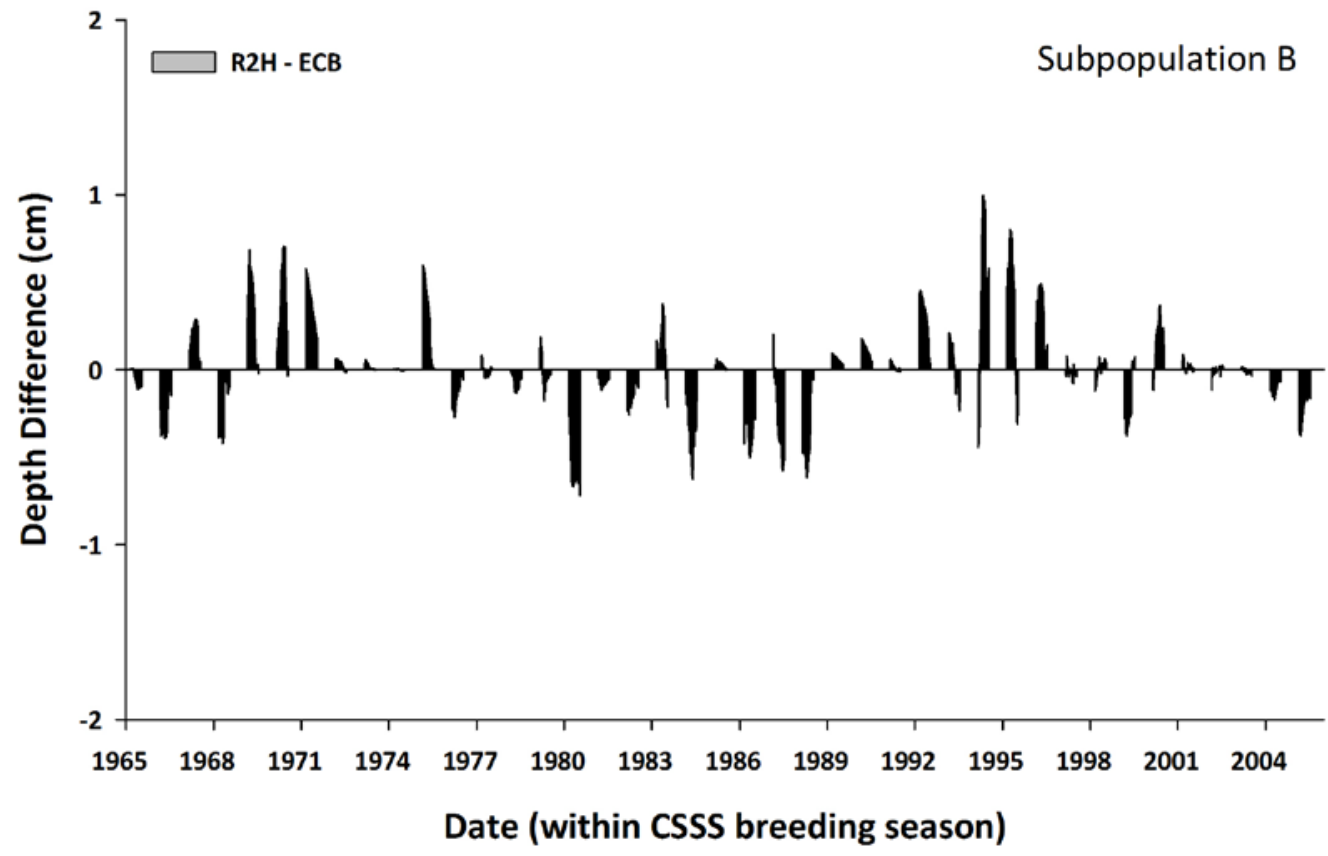

Figure 26. Graphs showing distribution and kernal probability curve of mean subpopulation water depths during, $A$, early (Mar-Apr) and, $B$, late (May-July 15) breeding seasons, and $C$, daily difference in water depth between the R2H scenario and baseline condition (ECB), in subpopulation B. [cm, centimeter; CSSS, Cape Sable seaside sparrow] 

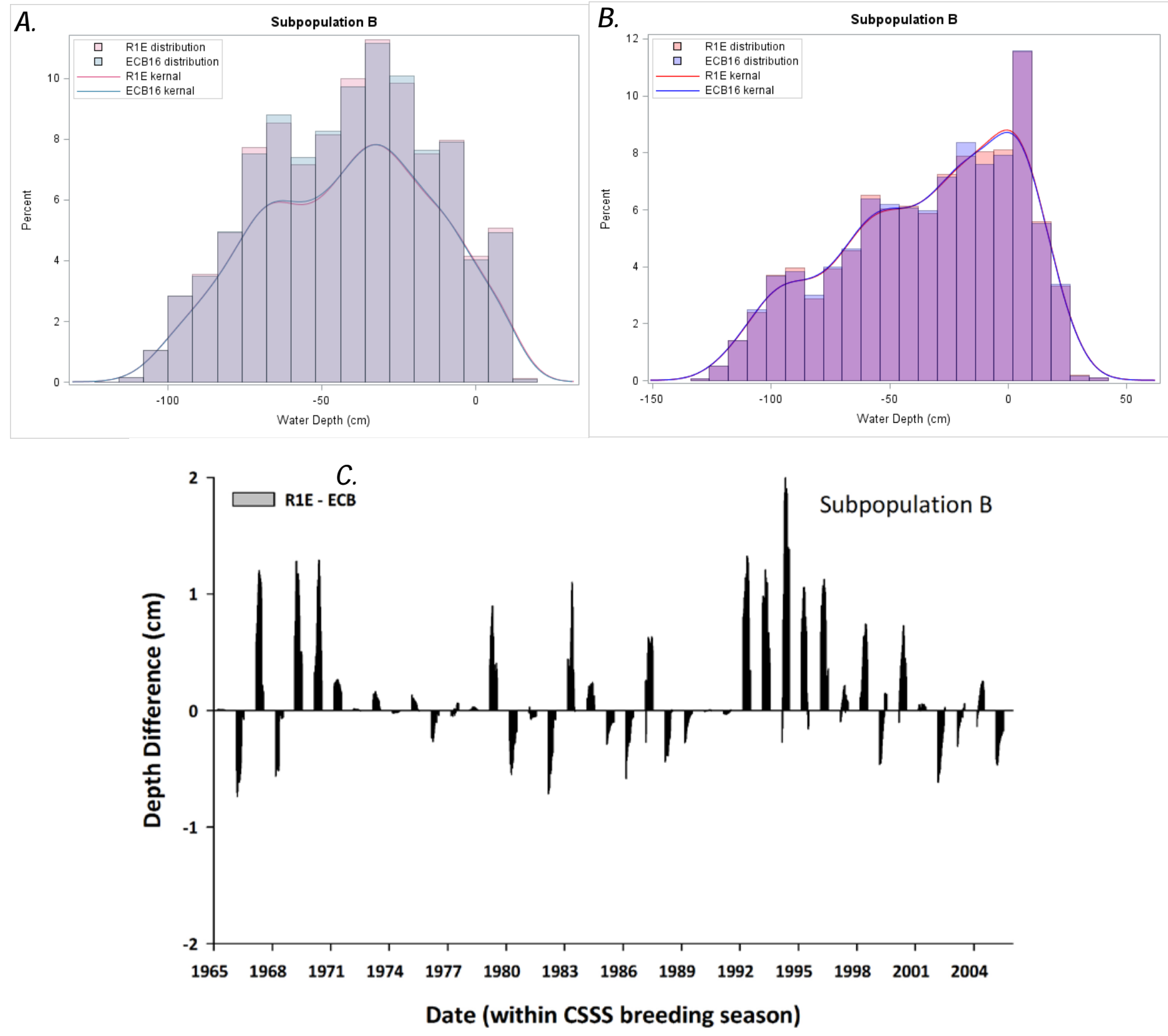

Figure 27. Graphs showing distribution and kernal probability curve of mean subpopulation water depths during, $A$, early (Mar-Apr) and, $B$, late (May-July 15) breeding seasons, and $C$, daily difference in water depth between the R1E scenario and baseline condition (ECB), in subpopulation B. [cm, centimeter; CSSS, Cape Sable seaside sparrow] 


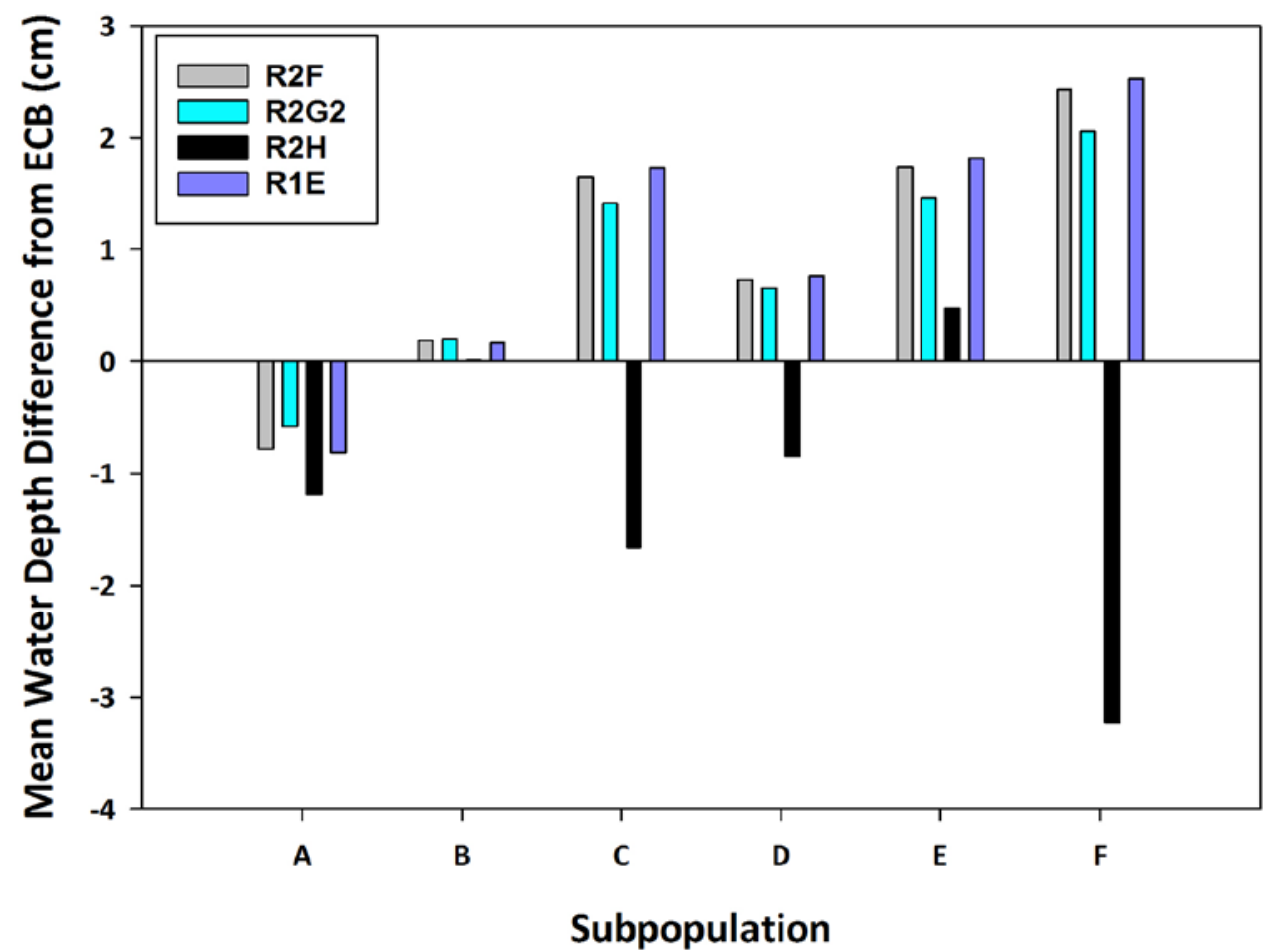

Figure 28. Graph showing mean water depth difference (centimeters; $\mathrm{cm}$ ) relative to the existing conditions baseline (ECB) across all breeding seasons (Mar-July 15, 1965-2005) for each scenario within each subpopulation. 

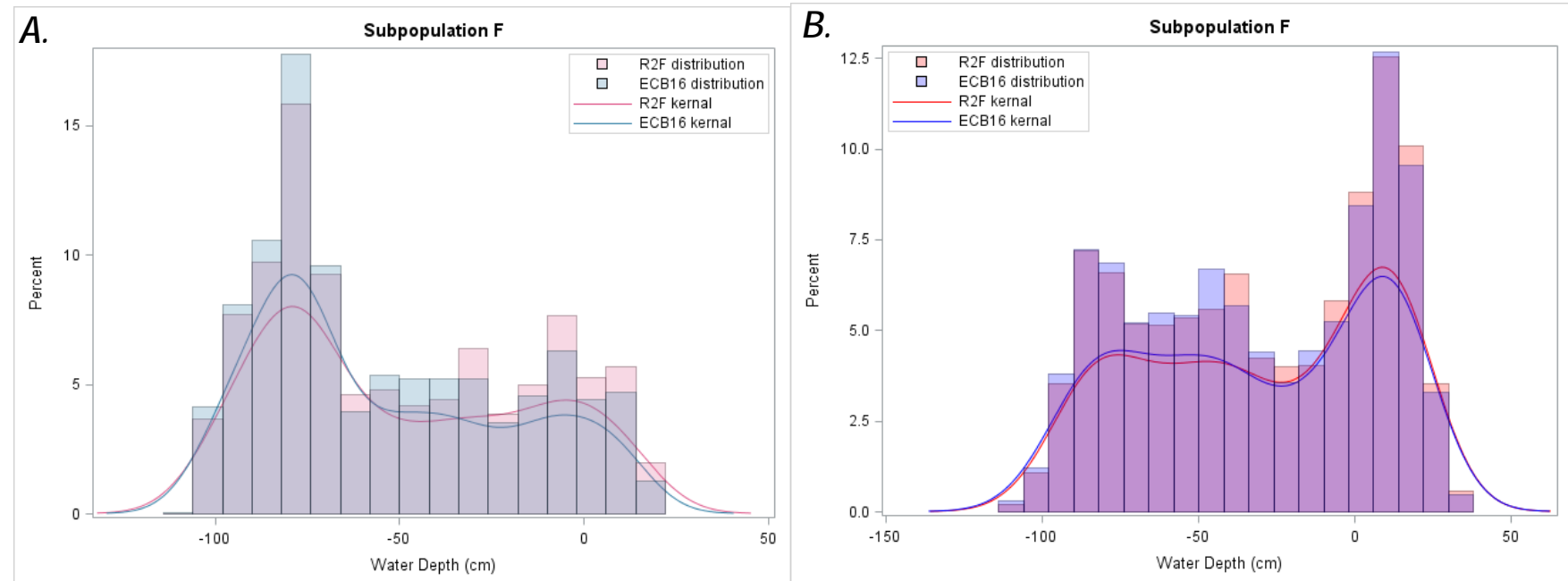

C.

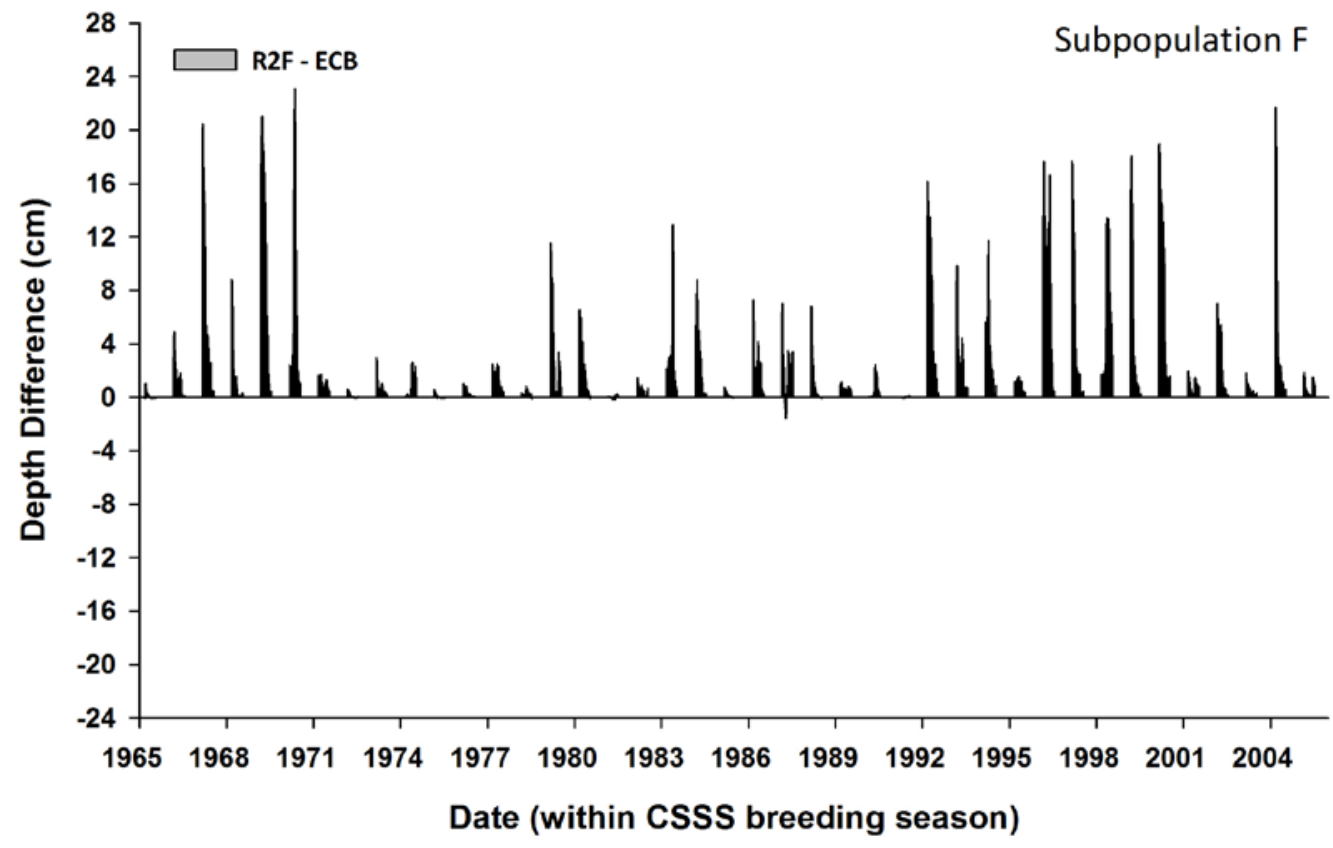

Figure 29. Graphs showing distribution and kernal probability curve of mean subpopulation water depths during, $A$, early (Mar-Apr) and, $B$, late (May-July 15 ) breeding seasons, and $C$, daily difference in water depth between the R2F scenario and baseline condition (ECB), in subpopulation F. [cm, centimeter; CSSS, Cape Sable seaside sparrow] 

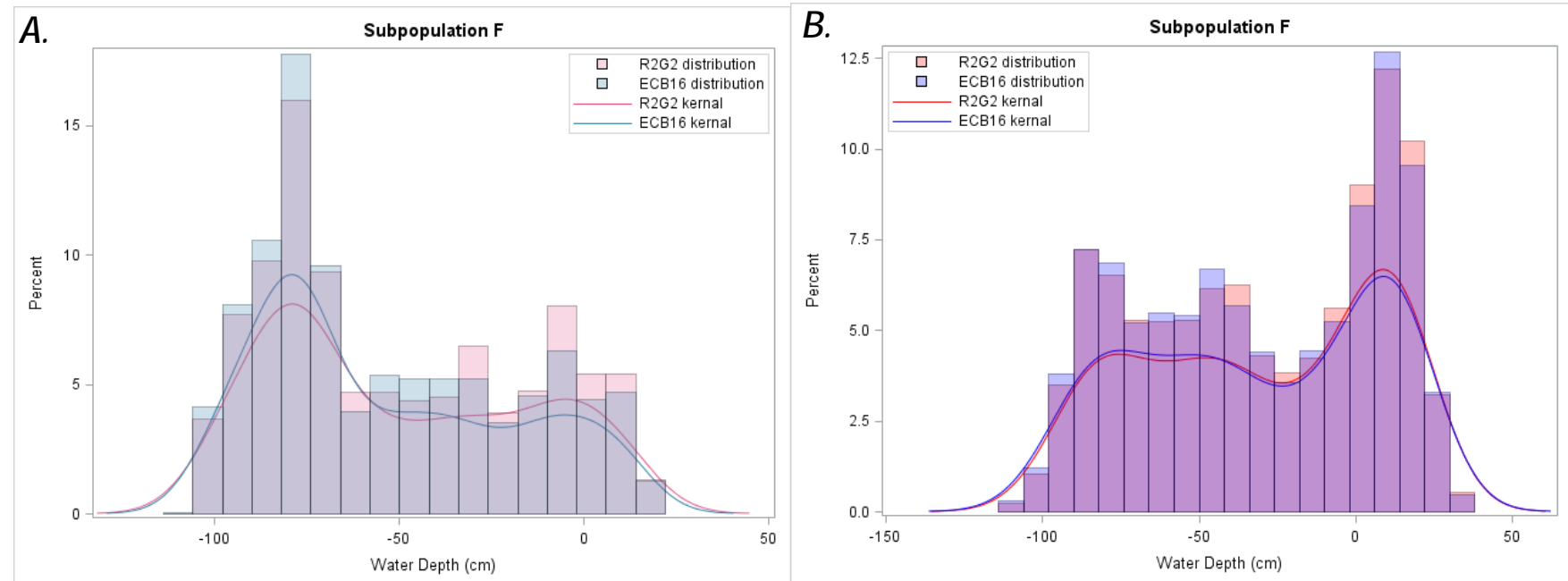

C.

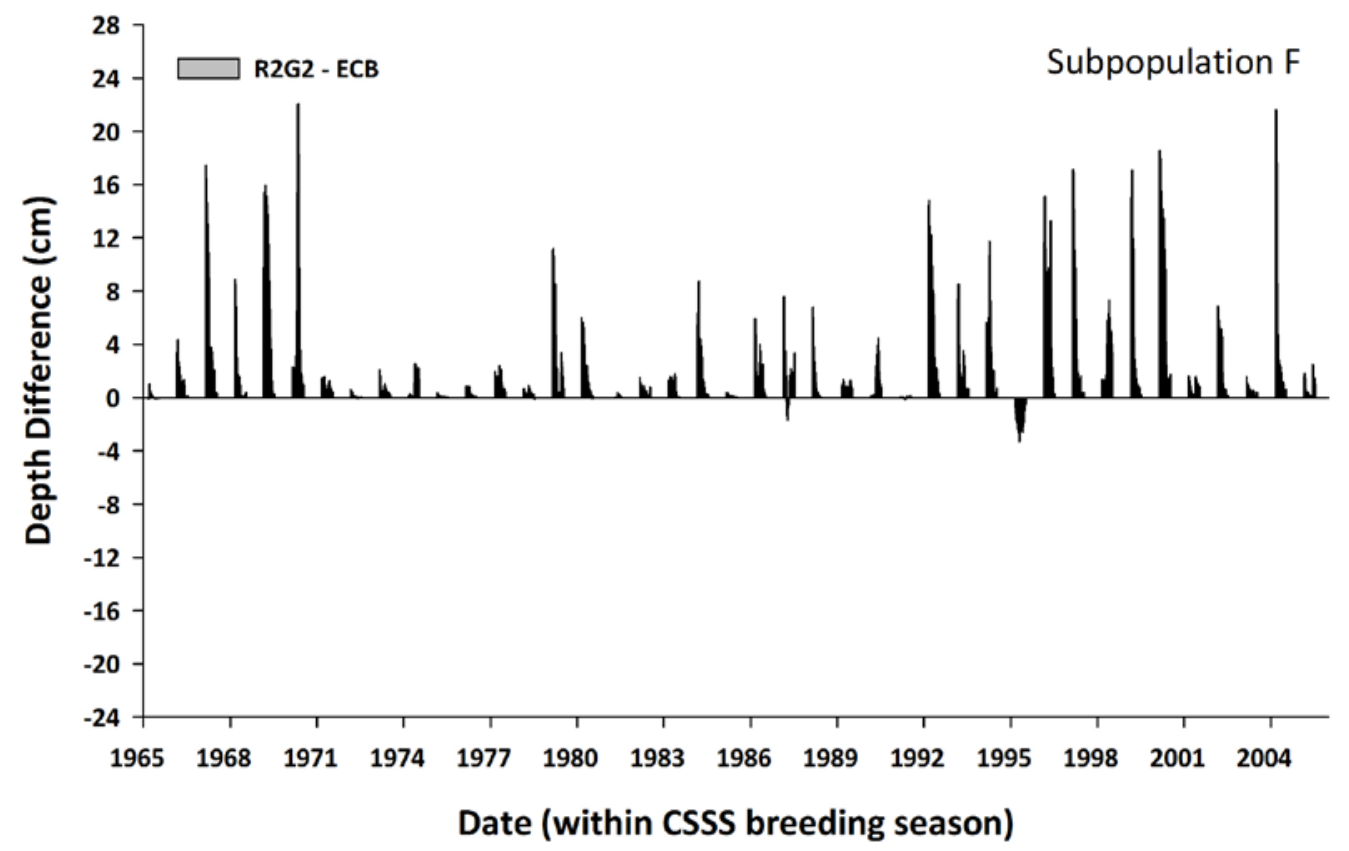

Figure 30. Graphs showing distribution and kernal probability curve of mean subpopulation water depths during, $A$, early (Mar-Apr) and, $B$, late (May-July 15) breeding seasons, and $C$, daily difference in water depth between the R2G2 scenario and baseline condition (ECB), in subpopulation F. [cm, centimeter; CSSS, Cape Sable seaside sparrow] 

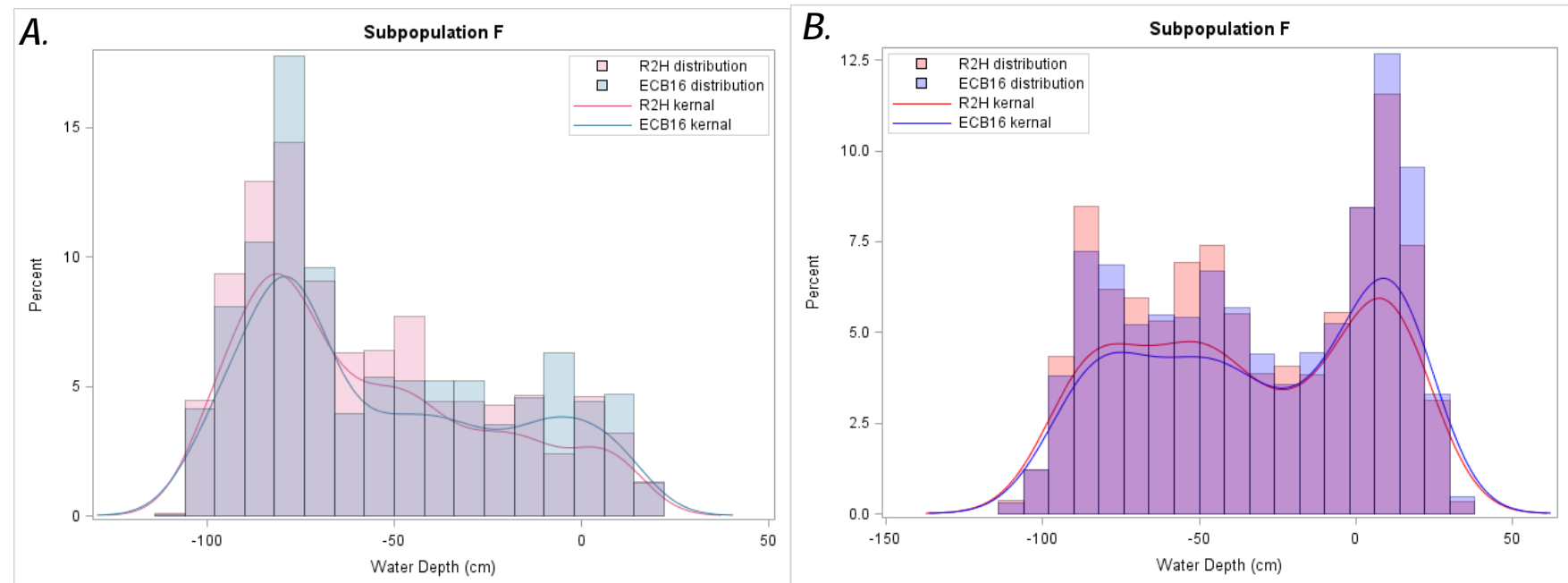

c.

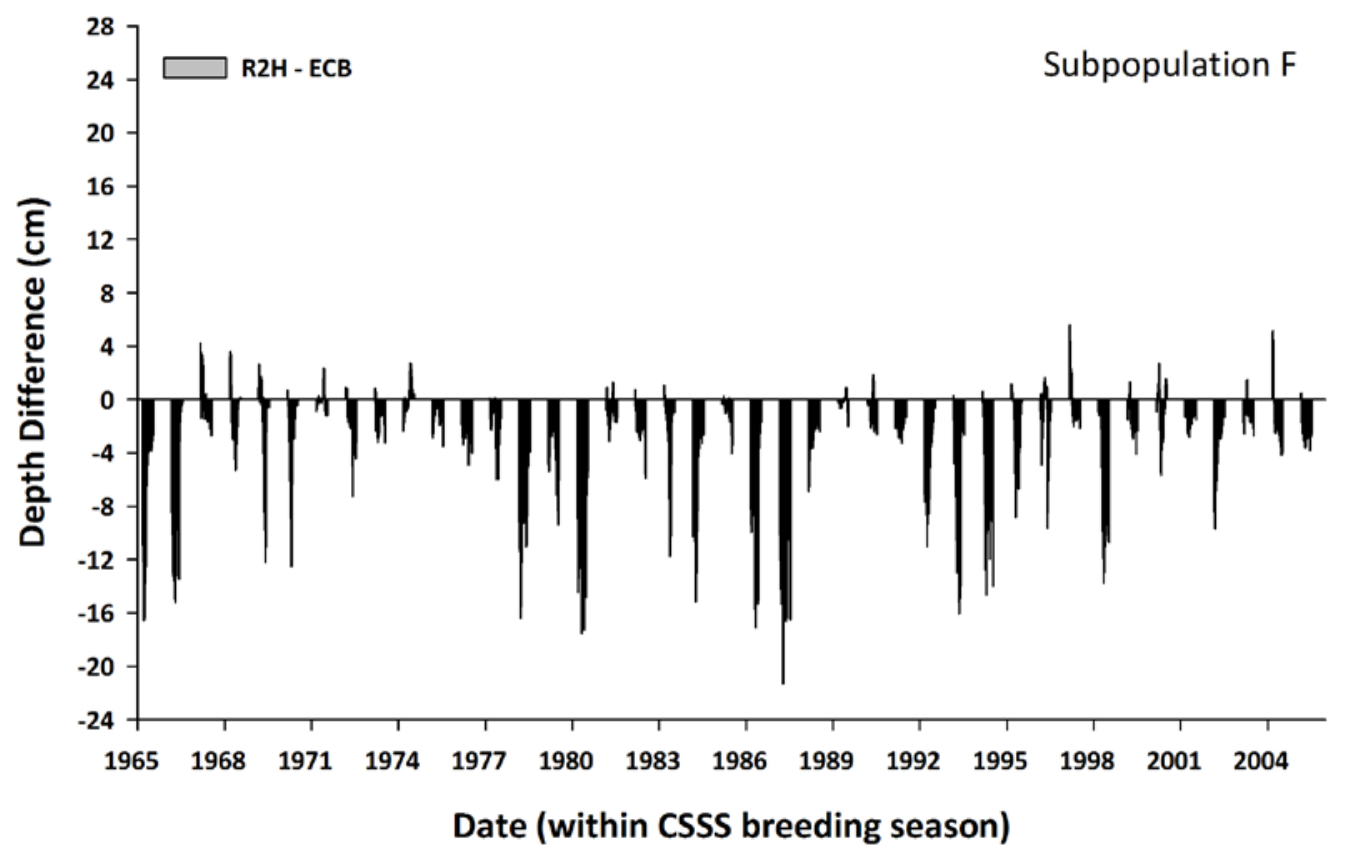

Figure 31. Graphs showing distribution and kernal probability curve of mean subpopulation water depths during, $A$, early (Mar-Apr) and, $B$, late (May-July 15) breeding seasons, and $C$, daily difference in water depth between the $\mathrm{R} 2 \mathrm{H}$ scenario and baseline condition (ECB), in subpopulation F. [cm, centimeter; CSSS, Cape Sable seaside sparrow] 

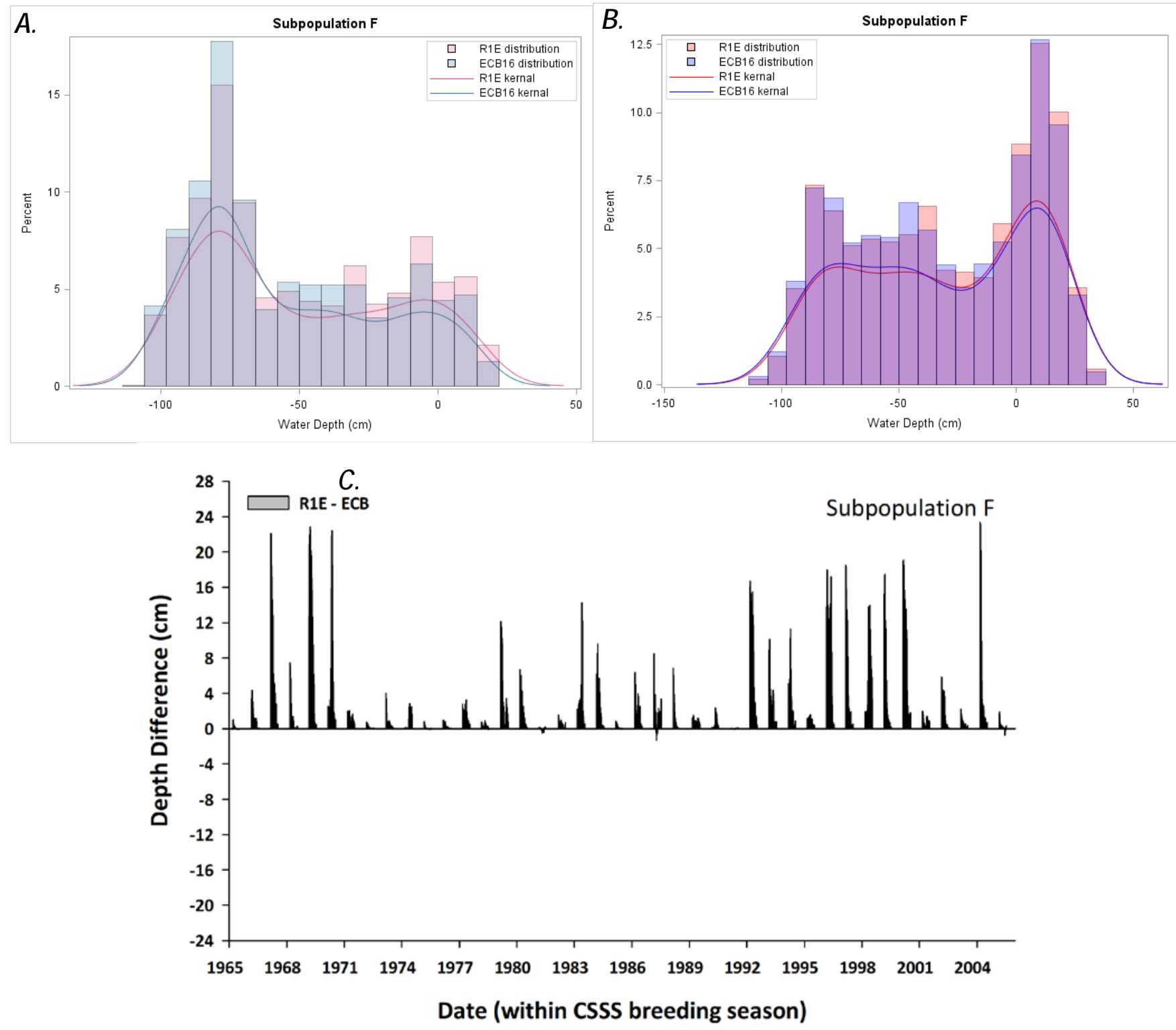

Figure 32. Graphs showing distribution and kernal probability curve of mean subpopulation water depths during, $A$, early (Mar-Apr) and, $B$, late (May-July 15) breeding seasons, and $C$, daily difference in water depth between the R1E scenario and baseline condition (ECB), in subpopulation F. [cm, centimeter; CSSS, Cape Sable seaside sparrow] 


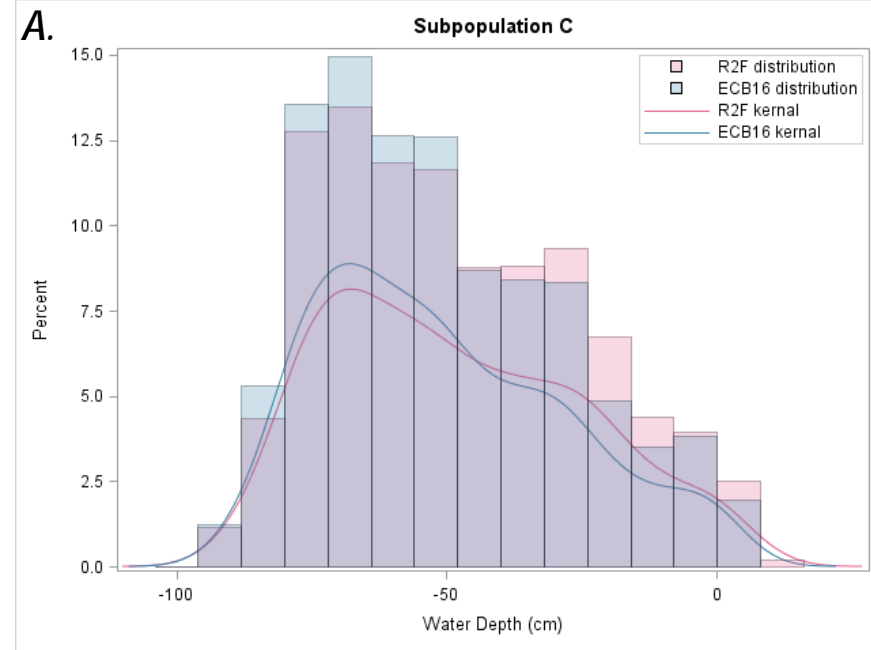

C.

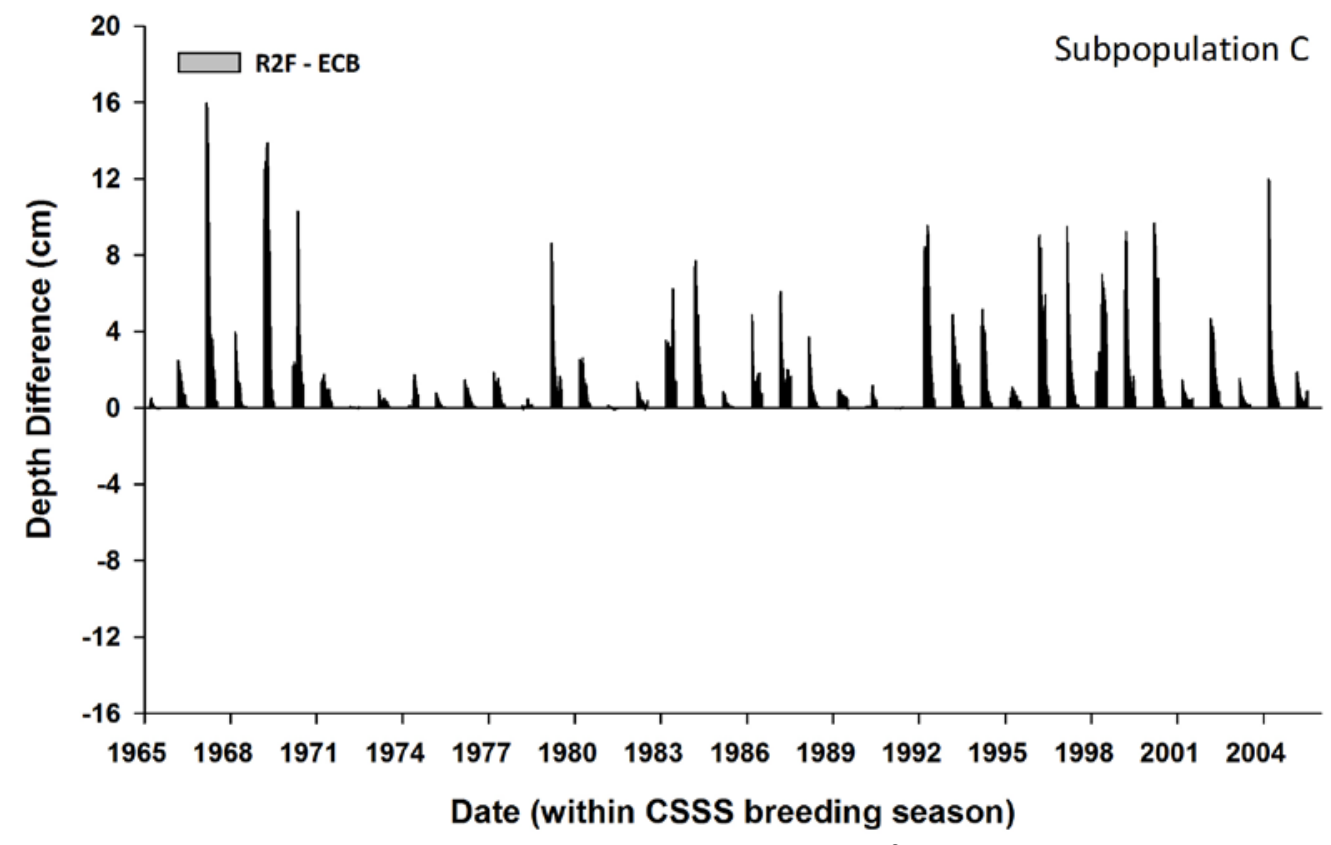

Figure 33. Graphs showing distribution and kernal probability curve of mean subpopulation water depths during, $A$, early (Mar-Apr) and, $B$, late (May-July 15) breeding seasons, and $C$, daily difference in water depth between the R2F scenario and baseline condition (ECB), in subpopulation C. [cm, centimeter; CSSS, Cape Sable seaside sparrow]

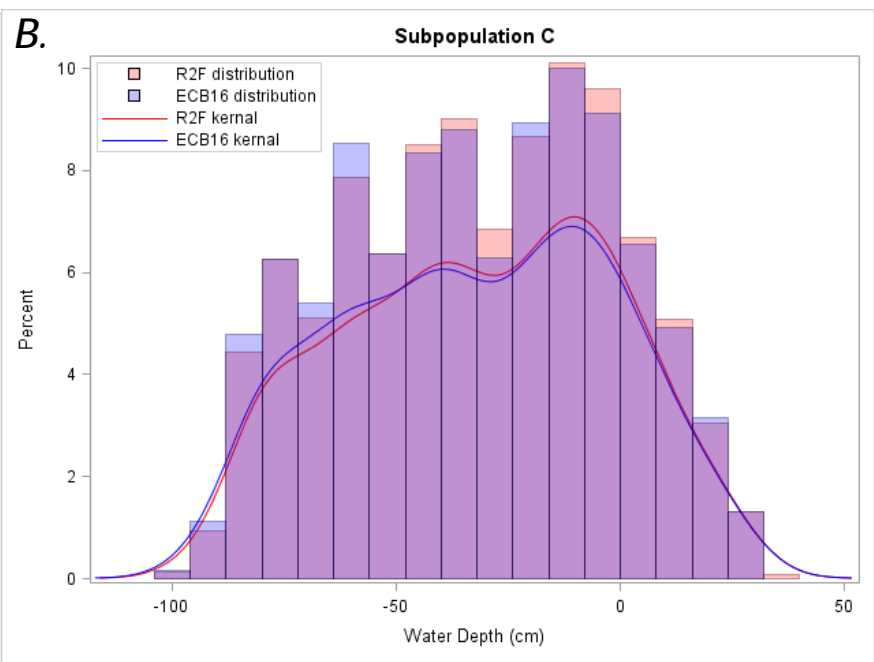

Subpopulation C 

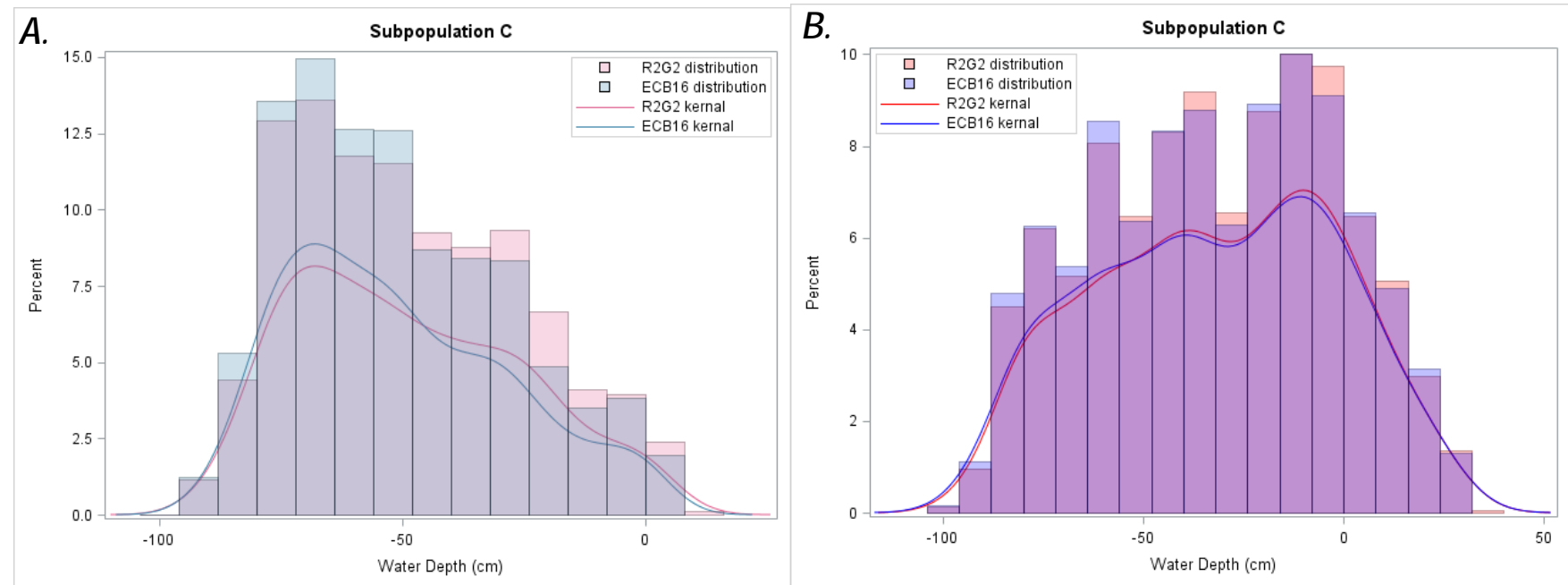

C.

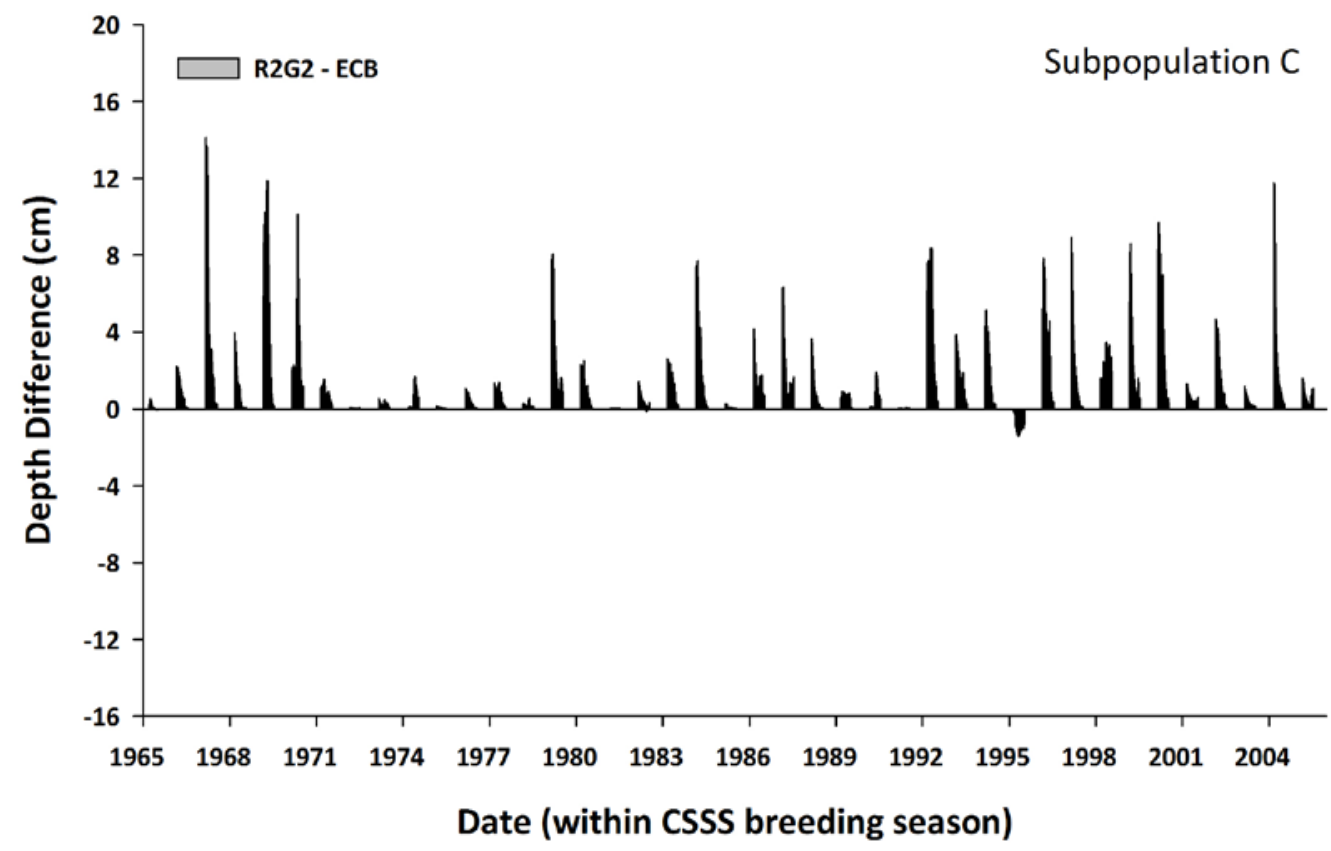

Figure 34. Graphs showing distribution and kernal probability curve of mean subpopulation water depths during, $A$, early (Mar-Apr) and, $B$, late (May-July 15) breeding seasons, and $C$, daily difference in water depth between the R2G2 scenario and baseline condition (ECB), in subpopulation C. [cm, centimeter; CSSS, Cape Sable seaside sparrow] 


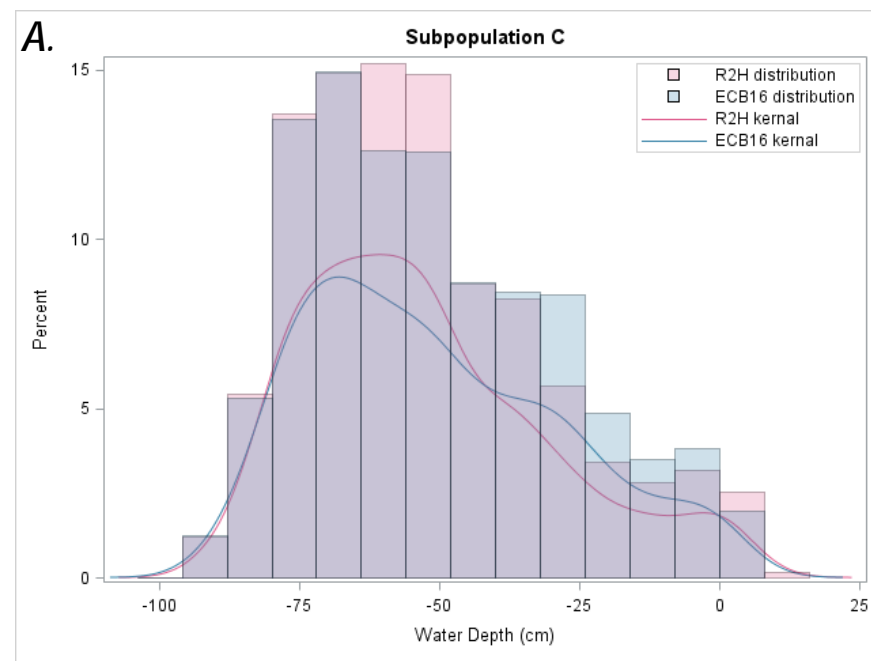

c.

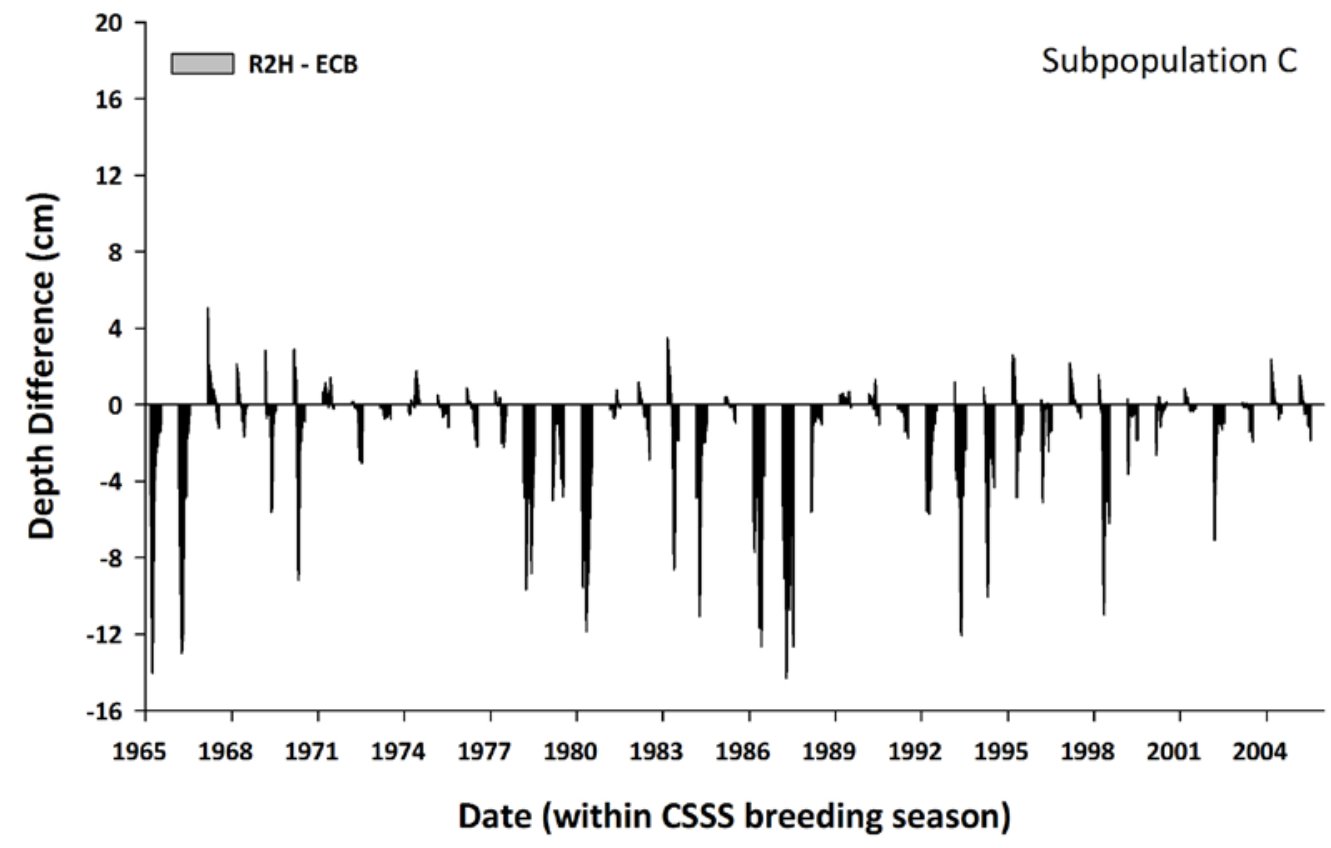

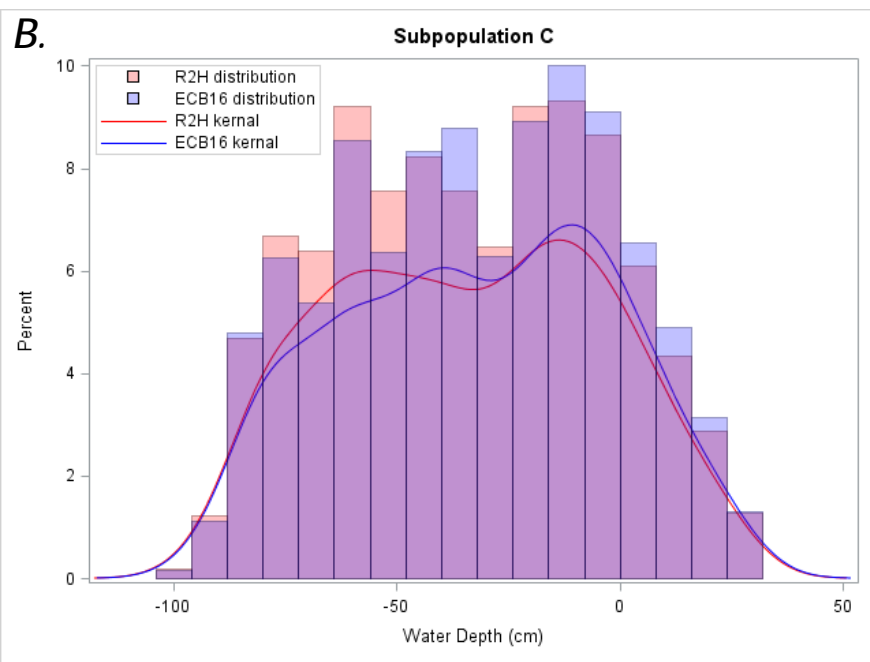



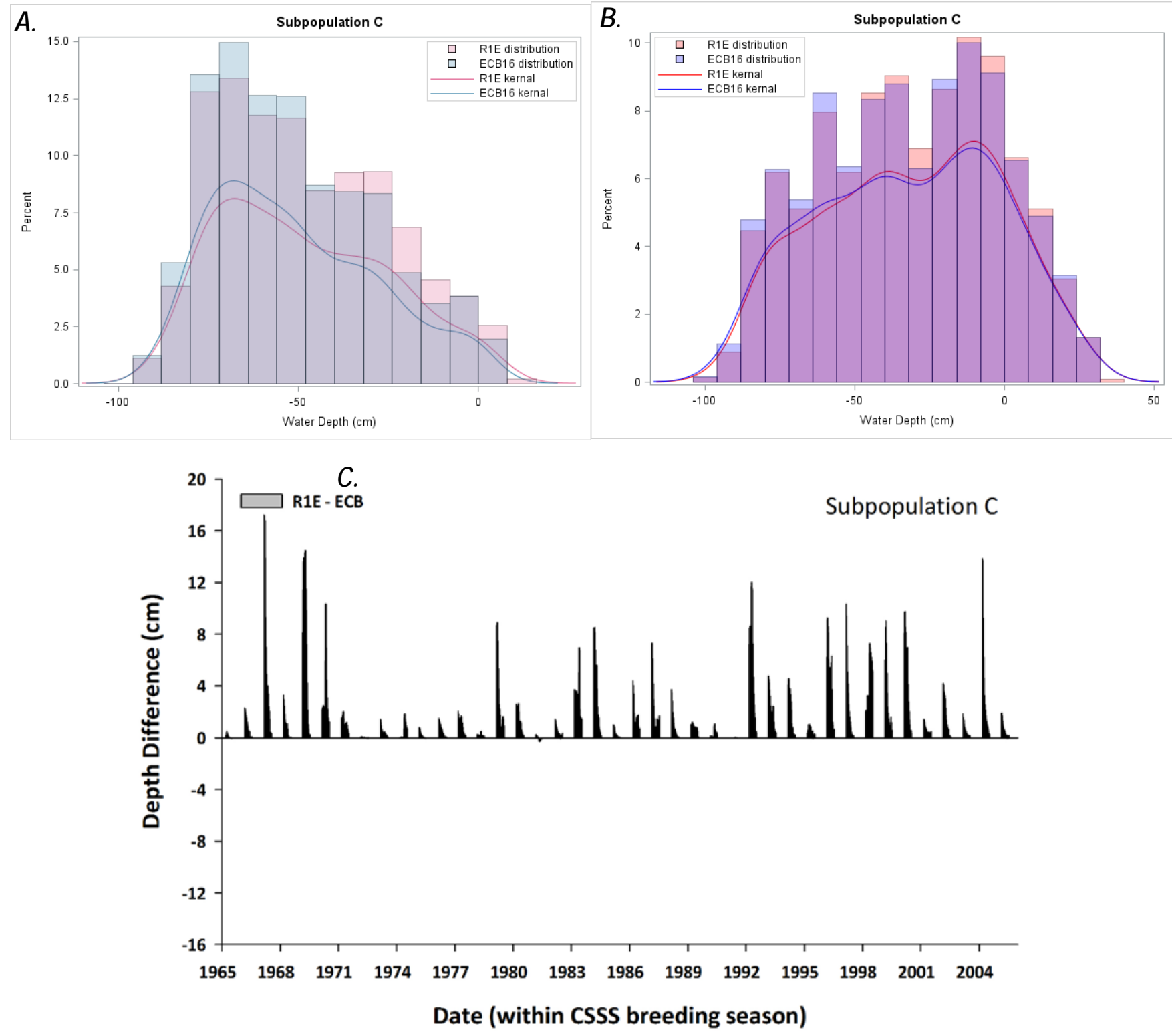

Figure 36. Graphs showing distribution and kernal probability curve of mean subpopulation water depths during, $A$, early (Mar-Apr) and, $B$, late (May-July 15) breeding seasons, and $C$, daily difference in water depth between the R1E scenario and baseline condition (ECB), in subpopulation C. [cm, centimeter; CSSS, Cape Sable seaside sparrow] 


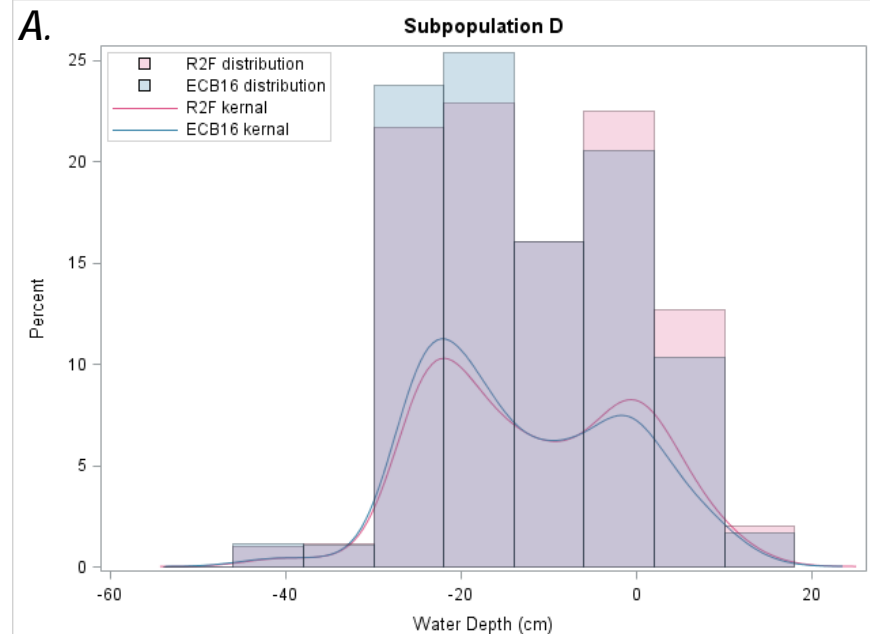

c.

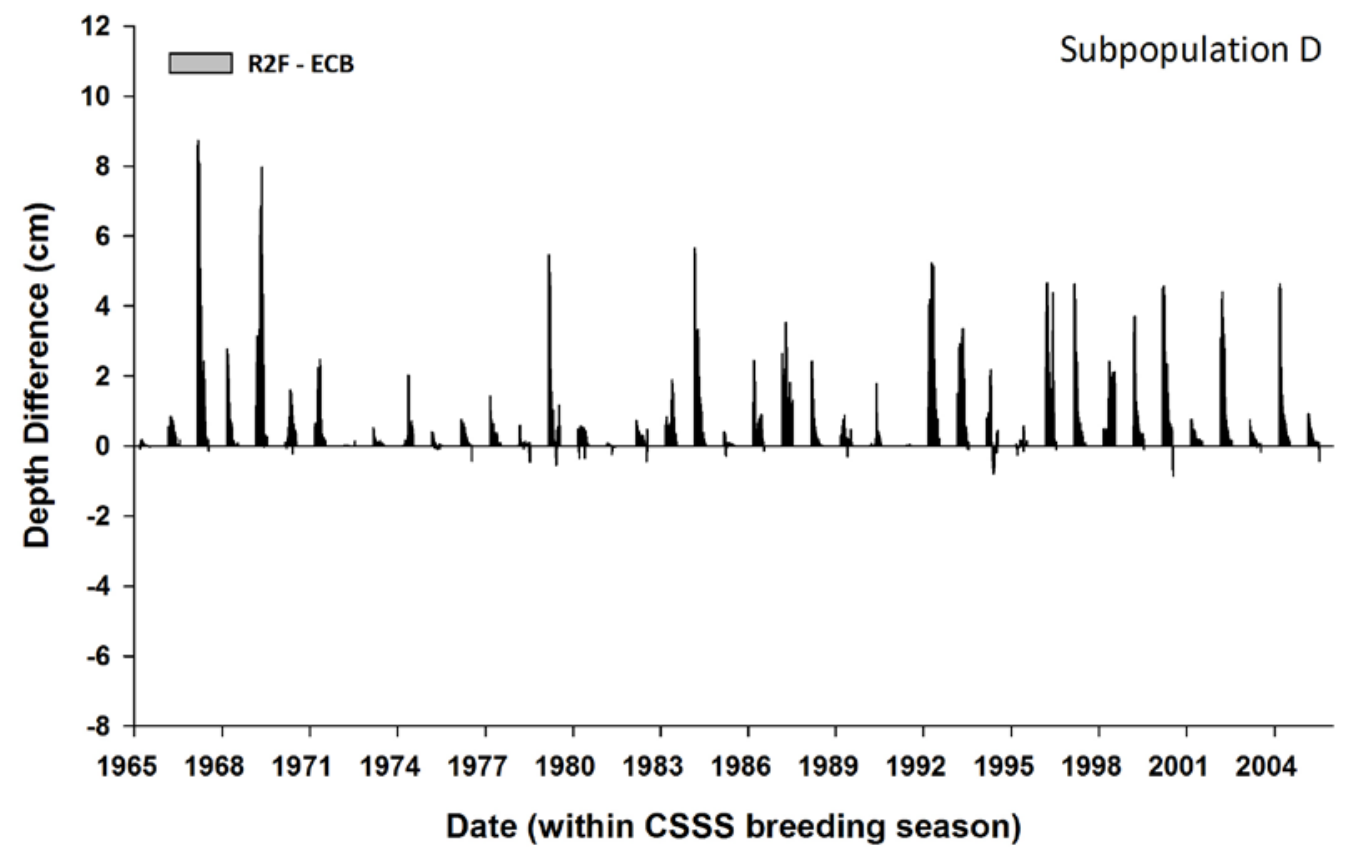

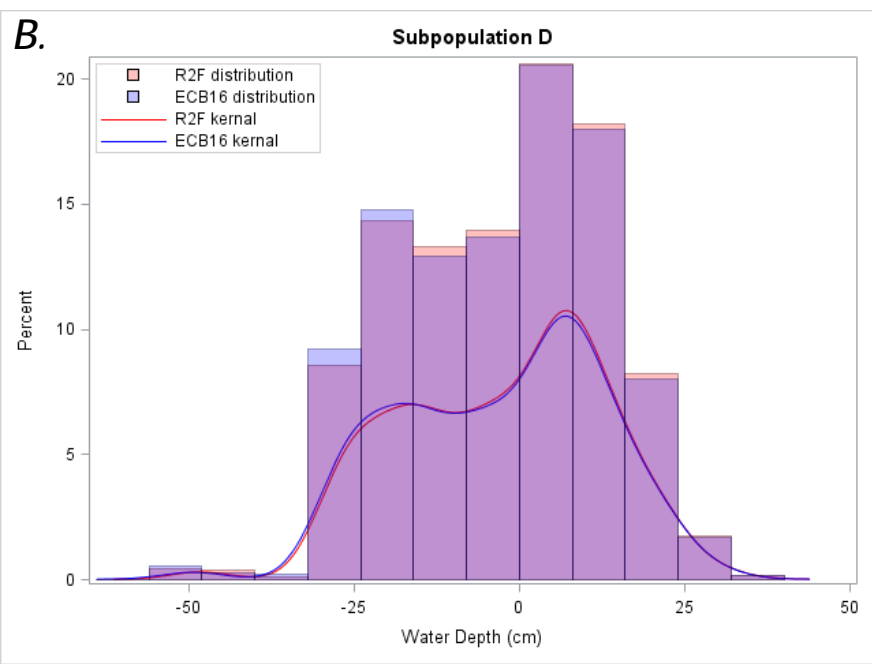

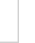



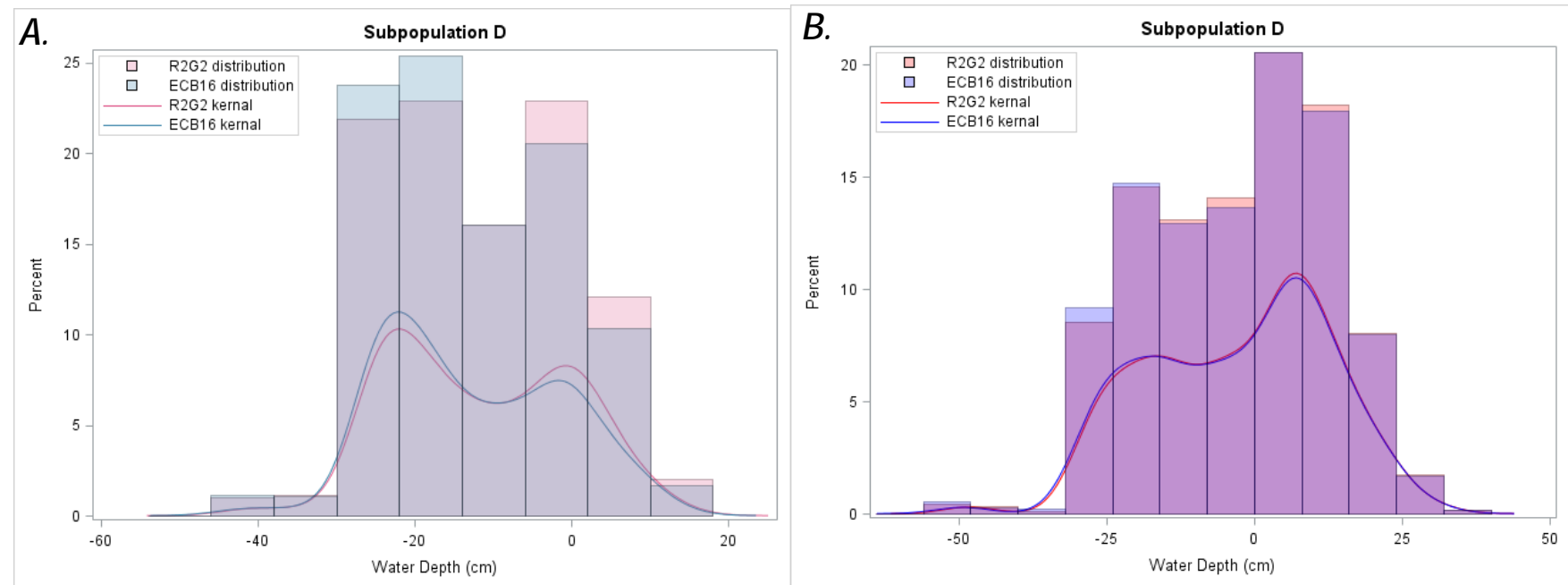

c.

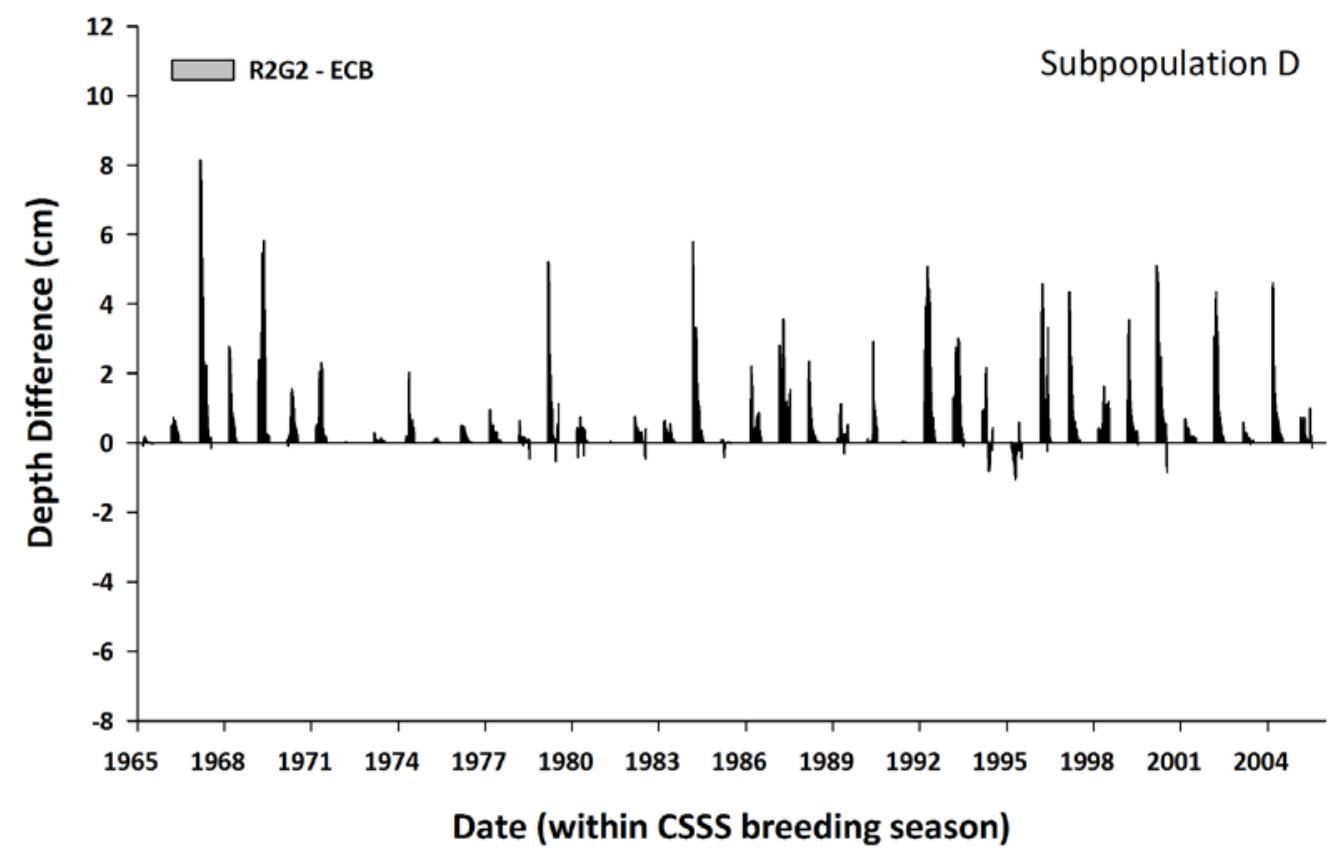

Figure 38. Graphs showing distribution and kernal probability curve of mean subpopulation water depths during, $A$, early (Mar-Apr) and, $B$, late (May-July 15) breeding seasons, and $C$, daily difference in water depth between the R2G2 scenario and baseline condition (ECB), in subpopulation D. [cm, centimeter; CSSS, Cape Sable seaside sparrow] 
A.

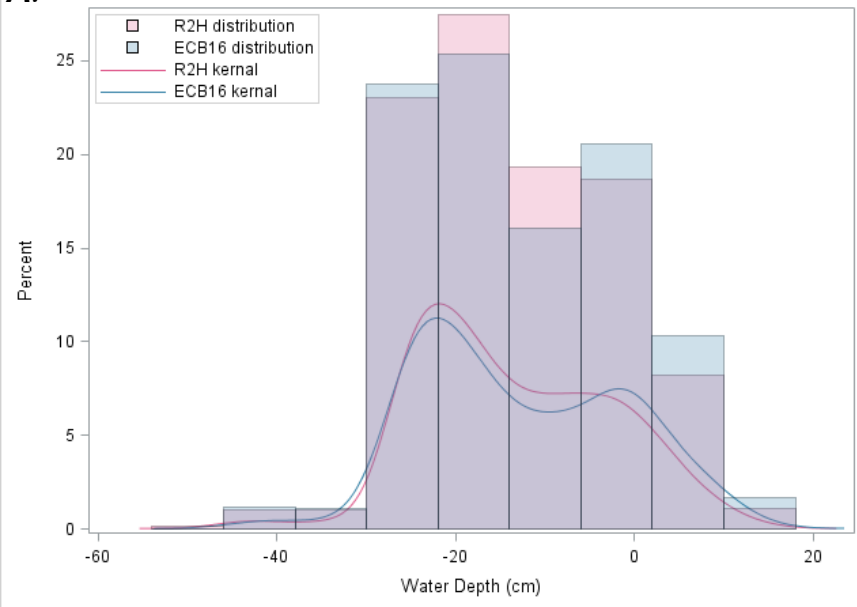

c.

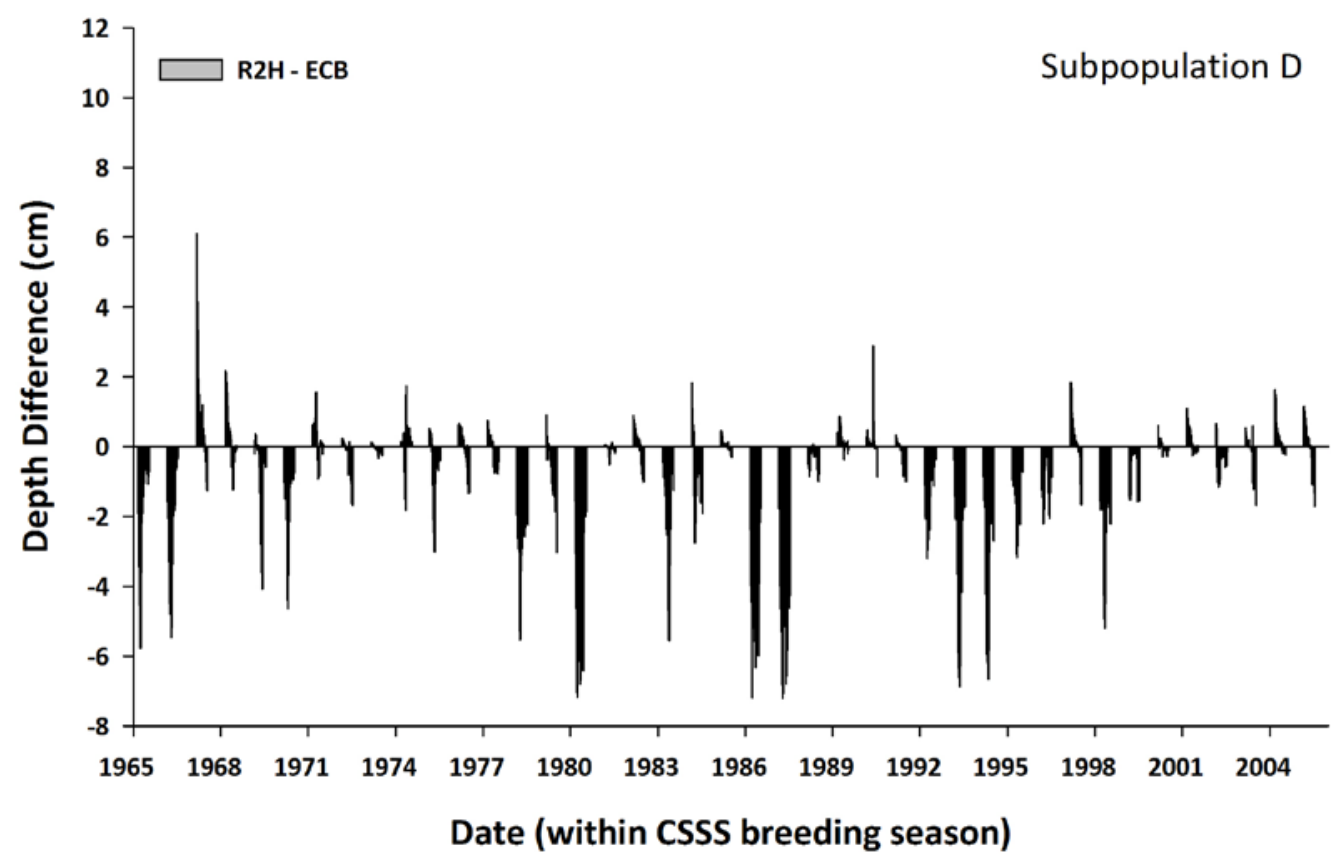

B.

Subpopulation D

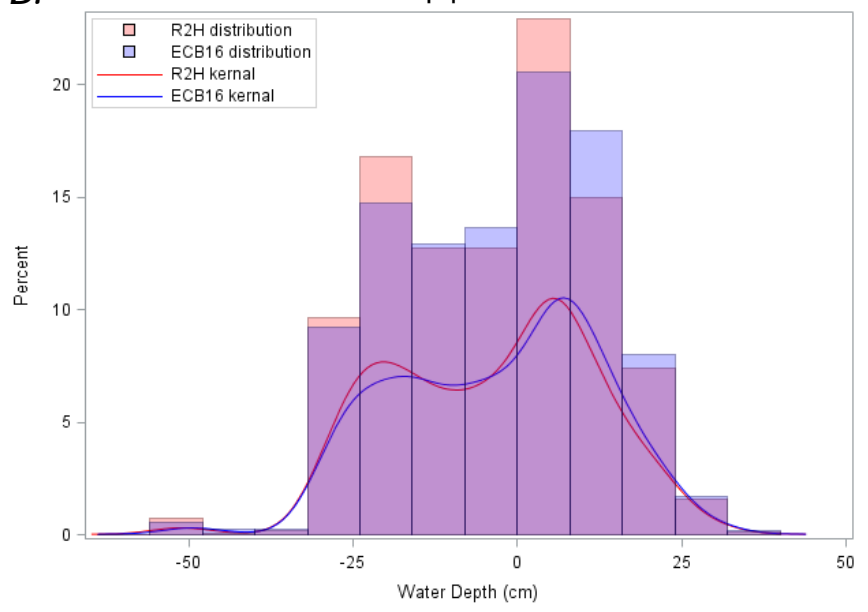

Water Depth $(\mathrm{cm})$ 

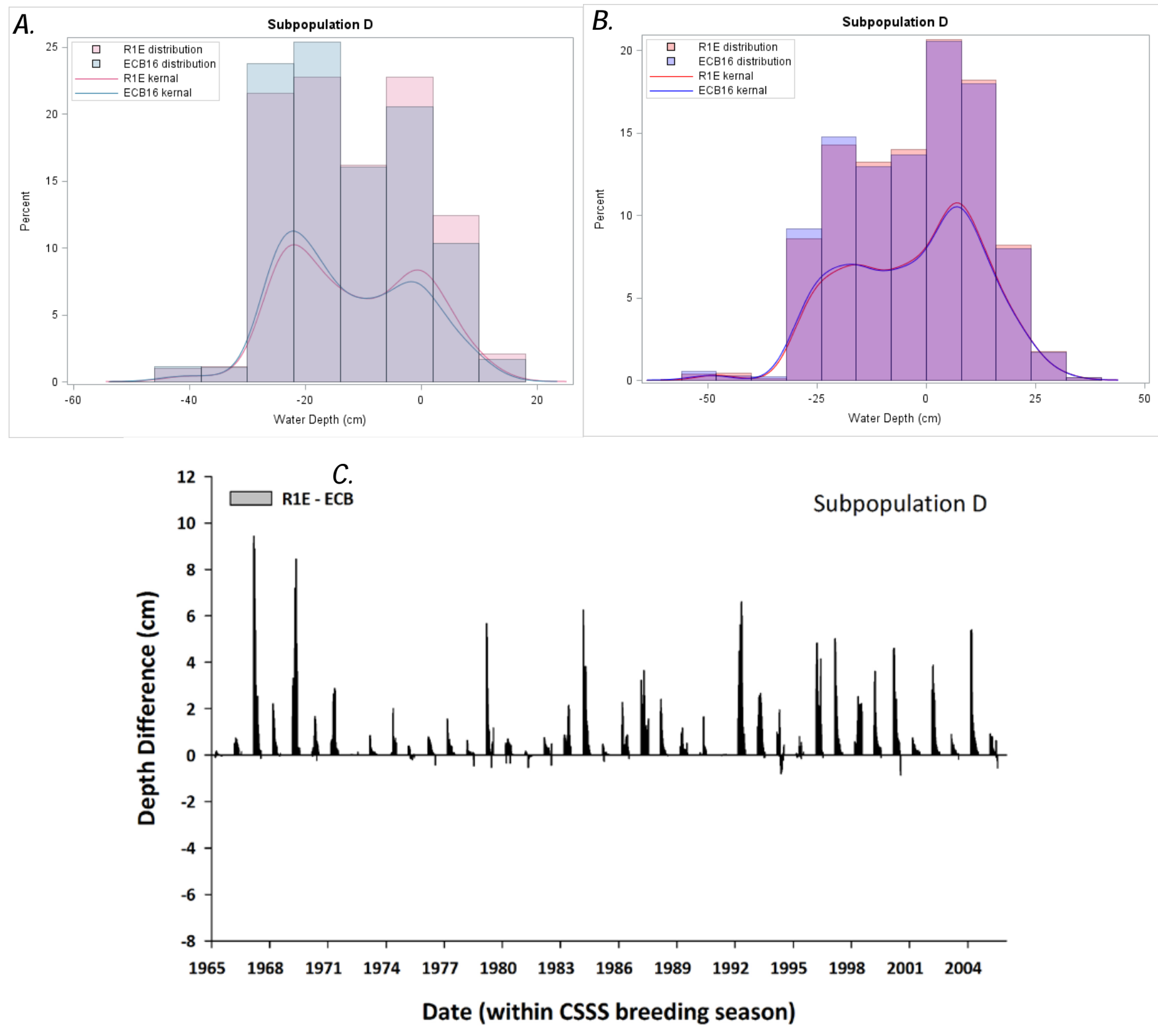

Figure 40. Graphs showing distribution and kernal probability curve of mean subpopulation water depths during, $A$, early (Mar-Apr) and, $B$, late (May-July 15) breeding seasons, and $C$, daily difference in water depth between the R1E scenario and baseline condition (ECB), in subpopulation D. [cm, centimeter; CSSS, Cape Sable seaside sparrow] 
Table 1. Description of water management scenarios modeled by the South Florida Water Management District. [WCA, water conservation area; ENP, Everglades National Park; SFWMD, South Florida Water Management District; CSSS, Cape Sable seaside sparrow]

Scenario name Description of scenario

Existing conditions Update previous base condition runs developed for Central Everglades Planning

baseline (ECB) $\quad$ Process (CEPP) and South Dade Investigation for current features and Everglades Restoration Transition Plan operations. Priority use of S-333 for WCA-3A Rainfall Plan deliveries, followed by S-12D, S-12C, S-12B, S-12A, L-28 Tie-Back Levee gaps and L-28 Canal Old Tamiami Trail Borrow Canal, with Tram Road east-west culvert $\mathrm{S}-12$ gate overtopping if headwater stage exceeds 11.0 feet.

R2F January through December closure period for S-12A, S-343A, S-343B and S-344; closure of S-12B from October 1 through August 16.

R2G2 Conditional closures of S-12A, S-12B, S-343A, S-343B and S-344 based on antecedent conditions in WCA-3A and sparrow breeding opportunity. Structures tend to open as stages increase at 3A-28 (should also help to avoid "overtopping" operations), tend to close during La Niña, neutral, and weak El Niño years.

R2H Early dry season operations (Sep-Dec) informed by SFWMD South Dade study to promote more flow toward ENP and extend hydroperiods; look for later dry season opportunity (Feb-May) to move water toward Biscayne National Park and away from CSSS populations; attempt to avoid water-level excursion above ground surface March 1 to July 15 because of operation of eastern infrastructure (S-332s, S-200s, S-199s).

R1E Closure of the ENP Tram Road borrow-canal connection, and January through December closure period for S-12A, S-12B, S-343A, S-343B, and S- 344. 
Table 2. Timespan and description of Cape Sable seaside sparrow variables processed to evaluate scenarios. [cm, centimeter; SD, standard deviation]

\begin{tabular}{lll}
\hline \multicolumn{1}{c}{ Variable } & \multicolumn{1}{c}{ Span } & \multicolumn{1}{c}{ Description } \\
\hline Depth mean of subpopulation & 1 day & Depth average of subpopulation \\
Consecutive dry days & 1 breeding season & Count of consecutive days with depth $>0 \mathrm{~cm}$ \\
Mean hydroperiod & 4 years & Mean count of days in year with depth $>0 \mathrm{~cm}$ \\
Hydroperiod variability & 4 years & SD of days in year with depth $>0 \mathrm{~cm}$ \\
\hline
\end{tabular}

